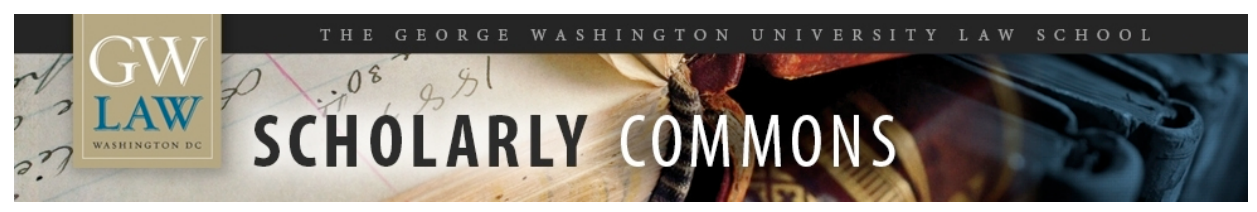

\title{
Clearing the Smoke from Philip Morris v. Williams: The Past, Present, and Future of Punitive Damages
}

Thomas Colby

George Washington University Law School, tcolby@law.gwu.edu

Follow this and additional works at: https://scholarship.law.gwu.edu/faculty_publications

Part of the Law Commons

\section{Recommended Citation}

Thomas Colby, Clearing the Smoke from Philip Morris v. Williams: The Past, Present, and Future of Punitive Damages, 118 Yale L. J. 392 (2009).

This Article is brought to you for free and open access by the Faculty Scholarship at Scholarly Commons. It has been accepted for inclusion in GW Law Faculty Publications \& Other Works by an authorized administrator of Scholarly Commons. For more information, please contact spagel@law.gwu.edu. 


\title{
THE YALE LAW JOURNAL
}

THOMAS B. COLBY

\section{Clearing the Smoke from Philip Morris v. Williams: The Past, Present, and Future of Punitive Damages}

\begin{abstract}
A B S T R A C T. In Philip Morris USA $v$. Williams, the Supreme Court held that the Constitution does not permit the imposition of punitive damages to punish a defendant for harm caused to third parties. This Article critiques the reasoning, but seeks ultimately to vindicate the result, of that landmark decision. It argues that, although the Court's procedural due process analysis does not stand up to scrutiny, punitive damages as punishment for third-party harm do indeed violate procedural due process, but for reasons far more profound than those offered by the Court. To reach that conclusion, the Article confronts the most basic and fundamental questions about punitive damages - questions that the Supreme Court has studiously avoided for more than a century: what, exactly, is the purpose of punitive damages, and how is it constitutional to impose them as a form of punishment in a judicial proceeding without affording the defendant the protection of the Constitution's criminal procedural safeguards? The Article argues that punitive damages are properly conceptualized as a form of punishment for private wrongs: judicially sanctioned private revenge. As such, it makes both theoretical and doctrinal sense to impose them without affording the defendant criminal procedural protections, which are necessitated only for the punishment of public wrongs on behalf of society. When, however, courts employ punitive damages as a form of punishment for public wrongs, they become a substitute for the criminal law, which thus makes an intolerable end run around the Bill of Rights. For that reason, Williams was ultimately correct that punitive damages must be limited to punishment for the harm done to the individual plaintiff, not the harm done to the general public. This reasoning suggests that contrary to the emerging conventional wisdom, Williams does not stand in the way of the imposition of nonpunitive extracompensatory damages of the type favored by law and economics scholars as a means of forcing the defendant to internalize the costs of its behavior in order to achieve optimal deterrence.
\end{abstract}

A U THOR. Associate Professor, The George Washington University Law School. For helpful comments on earlier drafts of this Article, the author would like to thank Michael Abramowicz, Michael Allen, Judge Guido Calabresi, William Colby, David Fontana, Frederick Lawrence, Chip Lupu, Dan Markel, Christopher Robinette, Shilpa Satoskar, Sheila Scheuerman, Anthony Sebok, Catherine Sharkey, Jonathan Siegel, Peter Smith, Roger Trangsrud, Benjamin Zipursky, and the participants in the work-in-progress workshop at The George Washington University Law School. 


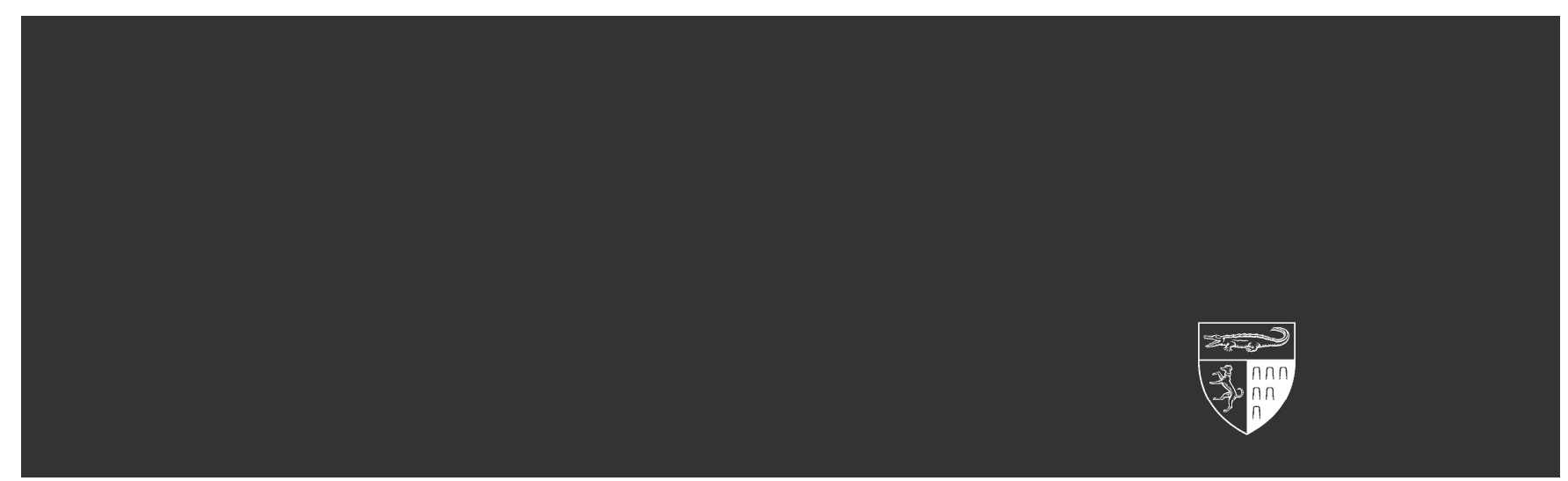

\section{ARTICLE CONTENTS}

INTRODUCTION

I. THE END OF TOTAL HARM PUNITIVE DAMAGES

II. PROCEDURE, SUBSTANCE, AND THE INADEQUACY OF WILLIAMS

A. Was the Williams Court's Purported Reliance on Procedural Due Process Just a Ruse?

401

B. The Williams Court's Inadequate Basis for Finding a Procedural Due Process Violation

IV. PRESENT: PROCEDURAL DUE PROCESS AND PUNISHMENT FOR PRIVATE WRONGS

A. Punishing Private Wrongs: Private Revenge 423

1. The Nature of Private Wrongs 424

2. Punishment and Compensation in Criminal and Civil Law 428

3. Public Retribution and Private Revenge 430

B. The Desirability of Punishing Private Wrongs 440

C. Constitutionality: Private Revenge and Criminal Procedure 444

D. Deterrence: The Elephant in the Room? 457

E. Evidence of Harm to Others To Determine Reprehensibility: The Exception that Swallowed the Rule? 


\section{INTRODUCTION}

Recently, in Philip Morris USA v. Williams, ${ }^{1}$ the Supreme Court held that "the Constitution's Due Process Clause forbids a State to use a punitive damages award to punish a defendant for injury that it inflicts upon nonparties." ${ }^{2}$ Williams is a revolutionary holding, and it was all but unthinkable just a few years ago, when American courts - with the apparent blessing of the Supreme Court - routinely awarded punitive damages to punish the defendant for the harm that it caused to all of society, not just the harm that it visited upon the individual plaintiff before the court. Indeed, it was that phenomenon that was largely responsible for most of the headline-grabbing, astronomical punitive damages awards of the past several decades.

Yet, for a path-breaking, five-to-four decision on a major constitutional question, the Williams opinion is strangely terse and unreasoned. This Article seeks to answer many of the questions raised by the Court's cryptic and at times misguided analysis, and to provide the theoretical defense of the Court's holding that is missing from its own opinion.

Part I explains how the Williams holding shattered the modern consensus that punitive damages can and should be imposed to punish the defendant for the full scope of the harm that it visited upon society. The Court reasoned that it violates due process to punish a defendant for harming a large number of people without demanding evidence relating to the particularities of each of those injuries and without affording the defendant the opportunity to raise individualized defenses. Part II exposes the Court's reasoning as internally inconsistent and insufficient to justify the result in the case.

Parts III and IV then seek to salvage Williams by explaining that punishing the defendant for harm to nonparties does indeed violate the defendant's procedural due process rights, but for reasons much more profound than those offered by the Court. That task necessitates paring the punitive damages doctrine down to the conceptual bone. In two centuries of issuing punitive damages decisions, the Supreme Court has never adequately answered the most simple and fundamental of questions: What, exactly, are punitive damages? What is their purpose? The Court has evaded those questions with superficial platitudes that ultimately do nothing more than raise a different but no less monumental question.

1. 127 S. Ct. 1057 (2007).

2. Id. at 1063 . 
The purpose of punitive damages, the Supreme Court has repeatedly told us, is to punish and deter, like the criminal law. ${ }^{3}$ But if that is so, then a deeper fundamental question looms: why are they constitutional? The Constitution makes clear that those who face criminal punishment are entitled to an array of procedural safeguards, including the burden of proof beyond a reasonable doubt, ${ }^{4}$ the privilege against self-incrimination, ${ }^{5}$ and the right to be free from double jeopardy, ${ }^{6}$ among others. The obvious objection to punitive damages is that it seems clearly unconstitutional to punish a defendant with a sanction that the Supreme Court concedes is conceptually and functionally indistinguishable from a criminal punishment without affording the procedural safeguards that the Constitution guarantees to criminal defendants. That objection has plagued punitive damages for well over a century. Yet the Supreme Court has never confronted it. ${ }^{7}$ Instead, the Court has consistently sidestepped the issue with the assurance that punitive damages must be constitutional because they predate the Constitution and the Framers manifested no intention to displace them.

Part III explains that this evasion will not do, for it is based on a profound misunderstanding of the historical purpose and function of punitive damages. Historically, punitive damages were generally treated as punishment for private wrongs to individuals, not public wrongs to society. History thus provides no safe harbor for modern awards of punitive damages designed to mimic the criminal law by punishing the defendant for the full scope of the harm that it inflicted upon society.

As such, what the Williams Court failed to recognize is that the constitutionality of awarding punitive damages for harm to nonparties cannot be resolved without confronting the fundamental question head on: how is it that punitive damages are constitutional? Part IV does just that. It concludes that the Constitution necessitates criminal procedural safeguards only when a sanction seeks to punish the defendant for a public wrong. Thus, punitive damages are constitutional if they fulfill their historical role of punishing the

3. See, e.g., State Farm Mut. Auto. Ins. Co. v. Campbell, 538 U.S. 408, 417 (2003); BMW of N. Am., Inc. v. Gore, 517 U.S. 559, 568 (1996).

4. See In re Winship, 397 U.S. 358 (1970).

5. See U.S. CONST. amend. V ("No person . . . shall be compelled in any criminal case to be a witness against himself....").

6. See id. ("[N] or shall any person be subject for the same offense to be twice put in jeopardy of life or limb....”).

7. See Benjamin C. Zipursky, A Theory of Punitive Damages, 84 TEx. L. Rev. 105, 131 (2005) (noting the Court's longstanding "disinclination to engage the civil-criminal gestalt in dealing with the applicability of constitutional criminal provisions" to punitive damages). 
defendant for the private wrong committed upon the individual plaintiff, but they are unconstitutional in their (pre-Williams) recent incarnation as punishment for the public wrong visited on society. In reaching this conclusion, Part IV seeks to provide a sophisticated theoretical and constitutional account of punitive damages as both sensible and permissible punishment for the harm to the plaintiff, but not as punishment for the harm to others. It argues that punitive damages are a form of legalized private revenge-both theoretically and constitutionally distinct from the public retribution and deterrence achieved through the criminal law. That is the true justification for the result in Williams: punishing the defendant for the harm to nonparties converts punitive damages into a criminal remedy, which the Constitution will not tolerate in a civil proceeding.

Part V looks ahead. Despite some loose language that others have interpreted as a debilitating loophole, Williams will, I assert, have a significant effect on reducing massive punitive damages awards. There is a risk that its impact will go too far, however, and result in the underdeterrence of harmful behavior. Part V addresses the states' ability to respond to that concern. Others have suggested that Williams essentially constitutionalizes one of the many rationales for punitive damages and forecloses the states from using punitive damages to achieve ends other than private punishment-such as ensuring efficient deterrence. In essence, they claim, Williams effectively serves as a federal license for companies to misbehave, cause diffuse harm, and profit from it. ${ }^{8}$ Part V rejects that claim by arguing that Williams does not constitutionalize one particular vision or theory of punitive damages (punishment for private wrongs) to the exclusion of all others; it simply provides that the Constitution precludes one (and only one) particular vision or theory of punitive damages (punishment for public wrongs - the prevailing modern theory). Williams thus allows the states to address the underdeterrence concern by implementing the recommendation of law and economics scholars to create a category of extracompensatory damages designed to ensure optimal deterrence. Such damages would not be a form of punishment, and thus-even though they would seek to serve a purely public interest-they would not constitute unconstitutional punishment for public wrongs. Once we take the punishment out of punitive damages, as law and economics scholars have been urging us to do for decades, we avoid the constitutional infirmity involved in Williams.

8. See, e.g., Michael L. Rustad, The Uncert-worthiness of the Court's Unmaking of Punitive Damages, 2 CHARLESTON L. REV. 459, 494 (2008). 


\section{THE END OF TOTAL HARM PUNITIVE DAMAGES}

In the decades leading up to Williams, punitive damages were, with increasing frequency, awarded to punish the defendant for the total harm that its wrongful conduct caused to all of society, not just the harm that it caused to the actual plaintiff or plaintiffs before the court ${ }^{9}-$ a sweeping sanction that I and others have referred to as "total harm" punitive damages. ${ }^{10}$ It was this phenomenon that was largely responsible for most of the jaw-dropping punitive damage awards in recent years. A jury that sees its mission as inflicting an appropriate punishment for causing thousands, or even millions, of injuries or deaths is likely to award punitive damages in an amount several orders of magnitude greater than it would award if it understood its task much more modestly as punishing the defendant for the wrong done only to the single victim before the court. To take a particularly striking example, in 2002, a California jury awarded a single smoker who contracted lung cancer $\$ 850,000$ in compensatory damages and $\$ 28$ billion-billion!-in punitive damages. ${ }^{11}$ That staggering punitive award was surely beyond the pale as punishment for causing only the plaintiff's illness and suffering; no rational justice system could possibly mete out that kind of penalty for harming a single person, no matter how severe the suffering and how reprehensible the wrongdoing. But it was not necessarily unreasonable as punishment for the harm done to the literally millions of smokers who were injured or killed by the defendant's fraud (if one concludes, as did the jury, that the tobacco company was guilty of maliciousness in knowingly causing those countless deaths and injuries). Plaintiff's counsel drove home this very point in closing argument:

Less than 3,00o people died in the Twin Towers terrorist attack. When I say 'less than,' that sounds really weird because what an unbelievable human toll; but in the terms we are talking about here, just so we can bring this down, that's a 30-day toll in California alone right now from smoking cigarettes. ${ }^{12}$

9. See Thomas B. Colby, Beyond the Multiple Punishment Problem: Punitive Damages as Punishment for Individual, Private Wrongs, 87 MINN. L. Rev. 583, 584-85 (2003); Catherine M. Sharkey, Punitive Damages as Societal Damages, 113 YALE L.J. 347, 349-51 (2003).

10. See, e.g., Colby, supra note 9, at 587; Thomas C. Galligan, Jr., Disaggregating More-ThanWhole Damages in Personal Injury Law: Deterrence and Punishment, 71 TENN. L. Rev. 117, 127 (2003); Rachel M. Janutis, Reforming Reprehensibility: The Continued Viability of Multiple Punitive Damages After State Farm v. Campbell, 41 SAN Diego L. ReV. 1465,1466 n.2 (2004).

11. See Bullock v. Philip Morris USA, Inc., 42 Cal. Rptr. 3 d 140, 151 (Ct. App. 2006).

12. Id. at 163 n.19. 
Awards of total harm punitive damages, including many in the multimillions of dollars, were commonplace in the years leading up to the Supreme Court's decision in Williams. ${ }^{13}$ The Williams case itself is typical of the phenomenon. Plaintiff Mayola Williams sued Philip Morris for causing the death of her husband, who died of lung cancer after many years of smoking Philip Morris cigarettes. In closing arguments, Williams's lawyer urged the jury to punish Philip Morris not only for the harm caused to her husband, but also for the harm visited upon all of the thousands of other smokers in the state who had been injured by smoking Philip Morris cigarettes. ${ }^{14}$ The jury apparently complied, awarding Williams $\$ 79.5$ million in punitive damages. The Oregon Supreme Court upheld the jury's award because Philip Morris's conduct "caused a significant number of deaths each year in Oregon" ${ }^{15}$ and, it concluded, there is nothing unconstitutional about "using punitive damages to punish a defendant for harm to nonparties." ${ }^{\prime 6}$

A decade ago, the Supreme Court of the United States seemingly agreed with that proposition. In BMW of North America, Inc. v. Gore, the Court held that federalism concerns preclude a state court from using punitive damages to punish a defendant for harm caused to out-of-state victims, at least where the defendant's conduct was legal in the other state, ${ }^{17}$ but the Court clearly, albeit implicitly, endorsed the notion that there is nothing wrong with allowing the jury to punish the defendant for the harm caused to all in-state victims, even those not before the court. ${ }^{18}$ That suggestion accorded with a consensus among courts and commentators that punitive damages are intended to serve as punishment for public wrongs-wrongs to society-and therefore should be

13. See Sharkey, supra note 9 , at 350-51.

14. See Philip Morris USA v. Williams, 127 S. Ct. 1057, 1061 (2007); Petition for Writ of Certiorari at 2, Williams, 127 S. Ct. 1057 (No. 05-1256).

15. Williams v. Philip Morris Inc., 127 P.3d 1165, 1170, 1175 (Or. 2006) (quoting Williams v. Philip Morris Inc., 48 P.3d 824, 839 (Or. 2002)).

16. Id. at 1175 .

17. 517 U.S. 559, 570-74 (1996). The Court subsequently extended that holding to preclude a state from punishing a defendant even for unlawful out-of-state conduct. See State Farm Mut. Auto. Ins. Co. v. Campbell, 538 U.S. 408, 421 (2003).

18. See $B M W, 517$ U.S. at $582 \& \mathrm{n} .35$ (evaluating whether the punitive damages award was excessive as punishment for the harm done to all of the in-state victims, rather than the harm done to the plaintiff alone); see also Michael P. Allen, The Supreme Court, Punitive Damages and State Sovereignty, 13 GEO. MASON L. REV. 1, 25 n.112 (2004); Colby, supra note 9, at 603-04 \& n.66. 
calibrated by reference to the full scope of harm that the defendant's conduct visited upon all of society. ${ }^{19}$

I took issue with that consensus in a 2003 article that concluded, based on an analysis of the origins and early evolution of punitive damages, that punitive damages historically were understood to serve as punishment for private wrongs to individuals, rather than as punishment for public wrongs to society. ${ }^{20}$ Given that history, I argued that, "to withstand constitutional scrutiny, all punitive damages awards must be designed (and limited to the amount necessary) to punish the defendant only for the wrong done, and the harm caused, to the individual plaintiff or plaintiffs before the court."21

Shortly after the publication of that article, the Supreme Court issued a cryptic opinion in State Farm Mutual Automobile Insurance Co. v. Campbell, in which it remarked that a "defendant should be punished for the conduct that harmed the plaintiff, not for being an unsavory individual or business. Due process does not permit courts, in the calculation of punitive damages, to adjudicate the merits of other parties' hypothetical claims against a defendant." ${ }^{22}$ Several courts and commentators interpreted Campbell as reversing course 180 degrees and precluding punishment for harm to nonparties. ${ }^{23}$ Drawing upon other seemingly contradictory passages in the

19. See Colby, supra note 9, at 586, 603-06 (describing this consensus, which emerged without reason or explanation over the last several decades).

20. See id. at $613-43$.

21. Id. at 591.

22. Campbell, 538 U.S. at 423 ; see also id. ("Nor does our review of the Utah courts' decisions convince us that State Farm was only punished for its actions toward the Campbells.").

23. See, e.g., Williams v. ConAgra Poultry Co., 378 F.3d 790, 797 (8th Cir. 2004); Guido Calabresi, The Complexity of Torts - The Case of Punitive Damages, in EXPLORING TORT LAW 333, 345-46 (M. Stuart Madden ed., 2005); Mark Geistfeld, Constitutional Tort Reform, 38 LOY. L.A. L. REV. 1093, 1099 (2005) (observing that the Court "effectively recognized that punitive damages must punish private wrongs ... and not the public wrong"); Zipursky, supra note 7, at 144 n.209. The California Court of Appeal, for instance, took the position that "Campbell ... essentially adopted the narrow view of punitive damages Professor Colby had articulated in his law review article appearing in print shortly before the Supreme Court decided Campbell." Allen, supra note 18, at 25-26 n.112 (discussing Romo v. Ford Motor Co., 6 Cal. Rptr. 3d 793 (Ct. App. 2003)); see Romo, 6 Cal. Rptr. 3d at 801 ("State Farm, in our view, impliedly disapproved this broad view of the goal and measure of punitive damages. Instead, as a matter of due process under the federal Constitution, the court adopted the more limited, historically based view of punitive damages." (citing Colby, supra note 9, at 667-73)); see also Galligan, supra note 10, at 126 \& n.53. In Johnson v. Ford Motor Co., 113 P.3d 82 (Cal. 2005), the California Supreme Court partially rejected the California Court of Appeal's conclusion. See id. at 92 ("The Romo court's analysis does not convince us that the United States Supreme Court, in State Farm, adopted wholesale the 'historical' view of 
Campbell opinion, however, other commentators interpreted the case much more narrowly-as breaking no new ground and in no way precluding punishment for harm to nonparties. ${ }^{24}$ Due to the inscrutability of the Campbell decision, the constitutionality of total harm punitive damages had been called into question but remained uncertain.

Williams put an end to the uncertainty. The Court declared that, although it had not squarely decided either in favor of the constitutionality of total harm punitive damages in $B M W$, or against their constitutionality in Campbell, it was now prepared to resolve the issue: "We did not previously hold explicitly that a jury may not punish for the harm caused others. But we do so hold now." 25

\section{PROCEDURE, SUBSTANCE, AND THE INADEQUACY OF WILLIAMS}

The Due Process Clause of the Fourteenth Amendment, ${ }^{26}$ like its counterpart in the Fifth Amendment, ${ }^{27}$ protects two distinct categories of rights, generally referred to as rights of "procedural" and "substantive" due process. ${ }^{28}$ The Clause is most naturally read to "requir[e] the government to follow appropriate procedures when its agents decide to 'deprive any person of life, liberty, or property."”29 This is the concept of procedural due process, which is typically concerned with giving fair notice and a fair hearing before the government deprives individuals of their liberty or property. ${ }^{30}$ But the Clause has long been interpreted to extend further to "bar[] certain

punitive damages outlined in the Colby article as a constitutional rule binding on the states." (citation omitted)).

24. Some commentators interpreted Campbell as forbidding only punishment for dissimilar acts that harmed third parties. See, e.g., Erwin Chemerinsky \& Ned Miltenberg, The Need To Clarify the Meaning of U.S. Supreme Court Remands: The Lessons of Punitive Damages' Cases, 36 ARIZ. ST. L.J. 513, 521-22 (2004). Other commentators interpreted Campbell as forbidding only punishment for out-of-state harm. See, e.g., Semra Mesulam, Note, Collective Rewards and Limited Punishment: Solving the Punitive Damages Dilemma with Class, 104 Colum. L. REV. 1114, 1128 (2004).

25. Philip Morris USA v. Williams, 127 S. Ct. 1057, 1065 (2007).

26. U.S. CONST. amend. XIV, $\mathbb{S} 1$ ("[N] or shall any State deprive any person of life, liberty, or property, without due process of law ....”).

27. U.S. CONST. amend. V ("No person shall ... be deprived of life, liberty, or property, without due process of law ....").

28. See Erwin Chemerinsky, Constitutional LaW: Principles and Policies 545 (3d ed. 2006).

29. Daniels v. Williams, 474 U.S. 327,331 (1986) (quoting U.S. Const. amend. XIV, $\mathbb{S} 1$ ).

30. See CHEMERINSKY, supra note 28 , at 545 . 
government actions regardless of the fairness of the procedures used to implement them." ${ }^{11}$ This is the concept of substantive due process, which is concerned with preventing governmental oppression ${ }^{32}$ and with protecting fundamental rights from governmental interference. ${ }^{33}$

\section{A. Was the Williams Court's Purported Reliance on Procedural Due Process Just a Ruse?}

In Williams, the Court purported to ground its holding in the doctrine of procedural due process, rather than its much-maligned substantive cousin. ${ }^{34}$ The Court's motivation for doing so is easy to explain: as it has reiterated many times, "the Court has always been reluctant to expand the concept of substantive due process." 35 Substantive due process, with its nominally oxymoronic nature and its dubious history of judicial overreaching, is the black sheep of constitutional rights. It operates in the murky shadows of Lochner $v$. New York, ${ }^{36}$ the poster child for the evils of "judicial activism." Partially ashamed of the substantive due process doctrine's very existence, the Court often struggles mightily to keep it confined to those shadows, out of the light of public and academic scrutiny. The United States Reports are full of landmark cases in which the Supreme Court, seeking to deflect comparisons to Lochner, has gone to drastic-sometimes ludicrous - lengths to avoid explicit reliance on substantive due process. ${ }^{37}$ As David Bernstein explains, "The ghost of Lochner

31. Daniels, 474 U.S. at 331

32. See id.

33. See Planned Parenthood of Se. Pa. v. Casey, 505 U.S. 833, 846-47 (1992). While the notion of "substantive due process" might sound linguistically awkward to contemporary ears, it in fact has a very long historical pedigree in our law. See Laurence H. Tribe, Taking Text and Structure Seriously: Reflections on Free-Form Method in Constitutional Interpretation, 108 HARV. L. REV. 1221, 1297 n.247 (1995).

34. See 127 S. Ct. 1057, 1063 (2004) ("[W]e need now only consider the Constitution's procedural limitations.").

35. Collins v. City of Harker Heights, 503 U.S. 115, 125 (1992).

36. 198 U.S. 45 (1905).

37. See, e.g., David E. Bernstein, Bolling, Equal Protection, Due Process, and Lochnerphobia, 93 GEO. L.J. 1253 (2005) (discussing Bolling v. Sharpe, 347 U.S. 497 (1954)); Tamar Ezer, A Positive Right to Protection for Children, 7 YAle Hum. RTs. \& DEv. L.J. 1, 22 (2004) (discussing DeShaney v. Winnebago County Dep't of Soc. Servs., 489 U.S. 189 (1989)); Ronald J. Krotoszynski, Jr., Expropriatory Intent: Defining the Proper Boundaries of Substantive Due Process and the Takings Clause, 8o N.C. L. Rev. 713, 739 (2002) (discussing the Court's regulatory takings jurisprudence); David D. Meyer, Lochner Redeemed: Family Privacy After Troxel and Carhart, 48 UCLA L. REV. 1125 (2001) (discussing the Court's family privacy 
v. New York haunts American constitutional law.... Supreme Court Justices are at pains to deny that their opinions declaring laws unconstitutional are Lochnerian, while dissenting Justices use Lochner as an epithet to criticize their colleagues." ${ }^{8}$ And when it comes to cases involving economic rights - such as, arguably, the right to be free from excessive punitive damages - the analogy to Lochner is disturbingly acute. Whenever the Court invokes the substantive due process doctrine to limit punitive damages, impassioned cries of Lochnerism inevitably follow. ${ }^{39}$

As such, the Court has always felt more comfortable imposing procedural due process limits on punitive damages than substantive ones. The Court has held, for instance, that procedural due process affords the defendant the right to judicial review of the size of the punitive damage award, ${ }^{40}$ and the right to de novo appellate review of the trial court's determination that the award was not excessive. ${ }^{41}$ In so holding, the Court has "strongly emphasized the importance of the procedural component of the Due Process Clause" in the realm of punitive damages. ${ }^{42}$

Some of the Court's punitive damages decisions, however, have gone beyond the realm of fair process to impose substantive constitutional limits on the size of punitive damages awards. And yet, so afraid is the Court of the ghost of Lochner that it has attempted to mask those substantive decisions in procedural garb.

Prior to its 1996 decision in BMW of North America, Inc. v. Gore, the Court had implied the existence of due process limits on the size of punitive damages awards, and it had explicitly suggested in dicta that those limits were grounded in substantive due process ${ }^{43}$ but it had never actually struck down an award of

opinions); Kathleen M. Sullivan \& Pamela S. Karlan, Foreword: The Elysian Fields of the Law, 57 STAN. L. REV. 695, 706-07 (2004) (discussing Skinner v. Oklahoma, 316 U.S. 535 (1942)); Richard G. Wilkins, The Structural Role of the Bill of Rights, 6 BYU J. PUB. L. 525, 546-47 (1992) (discussing Griswold v. Connecticut, 381 U.S. 479 (1965)).

38. David E. Bernstein, Lochner's Legacy's Legacy, 82 TEX. L. ReV. 1, 2-3 (2003).

39. See, e.g., Steven G. Calabresi, The Libertarian-Lite Constitutional Order and the Rehnquist Court, 93 GEO. L.J. 1023, 1052-53 (2005) (book review).

40. Honda Motor Co. v. Oberg, 512 U.S. 415 (1994).

41. Cooper Indus., Inc. v. Leatherman Tool Group, Inc., 532 U.S. 424 (2001).

42. Oberg, 512 U.S. at 420; see also Pac. Mut. Life Ins. Co. v. Haslip, 499 U.S. 1, 9 (1991) (declaring that "it is not disputed that a jury award [of punitive damages] may not be upheld if ... it was reached in proceedings lacking the elements of fundamental fairness'”(quoting Browning-Ferris Indus. of Vt., Inc. v. Kelco Disposal, Inc., 492 U.S. 257, $276(1989)))$.

43. See Oberg, 512 U.S. at 420; TXO Prod. Corp. v. Alliance Res. Corp., 509 U.S. 443, 453-54 (1993). 
punitive damages on those grounds. When, in $B M W$, the Court finally did strike down a punitive award as unconstitutionally excessive, it suddenly became cagey about just which component of the Due Process Clause formed the basis for its holding. The majority opinion never invoked the phrase "substantive due process"; it simply found a "due process" violation. ${ }^{44}$ Indeed, the majority opinion eschewed the word "substantive" altogether. ${ }^{45}$ Instead, in declaring the award unconstitutionally excessive, the Court emphasized that "[e]lementary notions of fairness ... dictate that a person receive fair notice ... of the severity of the penalty that a State may impose," and ultimately held that, because "BMW did not receive adequate notice of the magnitude of the sanction that Alabama might impose," the punitive damages award was "grossly excessive." 46 The requirement of adequate notice is, of course, traditionally associated with procedural due process, not substantive due process. $^{47}$

This nominal reliance in $B M W$ on procedural concepts was, however, illusory. Nearly the entirety of the Court's analysis was concerned with whether the award was "grossly excessive in relation to" the "State's legitimate interests in punishing unlawful conduct and deterring its repetition" $48-a$ quintessentially substantive inquiry. ${ }^{49}$ If the state had previously enacted a law publicly declaring that any company that commits a tort like the one committed by BMW can be punished by punitive damages in an amount up to $\$ 1$ billion - thus taking the issue of inadequate notice off the table - it is hard to believe that the Court's decision would have come out any differently. The Court's real problem with the punitive damages award in $B M W$ was that it was

44. BMW of N. Am., Inc. v. Gore, 517 U.S. 559, 562-63, 568 (1996); see Michael J. Phillips, The Progressiveness of the Lochner Court, 75 DENV. U. L. REV. 453, 471 n.110 (1998).

45. See Jeffrey R. White, State Farm and Punitive Damages: Call the Jury Back, 5 J. High TeCH. L. 79, 93 n.96 (2005).

46. $B M W, 517$ U.S. at $574-75$.

47. See TXO, 509 U.S. at 462-63 (noting that an argument that the defendant "had no advance notice that the jury might be allowed to return such a large award" of punitive damages is an argument "that the punitive damages award is the result of a fundamentally unfair procedure"); Paul M. Sykes, Marking a Road to Nowhere? Supreme Court Sets Punitive Damages Guideposts in BMW v. Gore, 75 N.C. L. REV. 1084, 1113 (1997).

48. 517 U.S. at 568 (citing $T X O, 509$ U.S. at 456 ).

49. See Cooper Indus., Inc. v. Leatherman Tool Group, Inc., 532 U.S. 424, 433-34 (2001) (citing $B M W$ for the proposition that the Due Process Clause imposes substantive limits on the imposition of "grossly excessive" punitive damages awards). 
too large, not that it was unexpected..$^{50}$ Indeed, both of the dissents in $B M W$ explicitly characterized the majority's evasive opinion as grounded in substantive due process, ${ }^{51}$ and the majority was unwilling or unable to directly take issue with that characterization.

Seven years later, in State Farm Mutual Automobile Insurance Co. v. Campbell, when the Court struck down an award of punitive damages as unconstitutionally excessive for a second time, it again paid lip service to the procedural notion of inadequate notice, and it again failed to acknowledge explicitly that it was relying on substantive due process. ${ }^{52}$ Yet it was again unwilling or unable to disagree with the dissenting opinions' characterization of its holding as grounded in substantive due process. ${ }^{53}$

It would appear that the Court's choice to couch its substantive decisions in $B M W$ and Campbell in procedural terms was the product of a defensive and not particularly convincing effort to ward off comparisons to Lochner. ${ }^{54}$ After all, there is nothing controversial or arguably oxymoronic about procedural due process, and a vigorous protection of procedural rights, even in economic cases, does not invite unwelcome analogies to the Lochner era.

Given that the Court had been ashamed of its reliance on substantive due process in the cases leading up to Williams and had gone to such extremes to disguise it, it is not surprising that it sought to couch its Williams holding in procedural terms as well. And it is equally unsurprising that the dissenting Justices did not believe a word of it. "It matters not," wrote Justice Thomas, "that the Court styles today's holding as 'procedural,' because the 'procedural' rule is simply a confusing implementation of the substantive due process

50. See, e.g., $B M W,{ }_{517}$ U.S. at 585-86 ("[W]e are fully convinced that the grossly excessive award imposed in this case transcends the constitutional limit."); id. at 575 n.24 (relying on the "principle that punishment should fit the crime").

51. See id. at 599 (Scalia, J., dissenting); id. at 613 (Ginsburg, J., dissenting).

52. See 538 U.S. 408, 417 (2003).

53. See id. at 429 (Scalia, J., dissenting); id. at 438 (Ginsburg, J., dissenting).

54. See Zipursky, supra note 7, at 117-18 ("[Justice Stevens] apparently felt pressure to tie the striking down of damages under the Due Process Clause to a familiar procedural concept: 'notice.' . . . And yet little or none of the analysis that follows addresses the issue of notice, at least not in any clear way."). 
regime this Court has created for punitive damages." ${ }^{55}$ Commentators have tended to agree. ${ }^{56}$

The majority opinion does, indeed, read in places as though the claimed reliance on procedural due process was simply window dressing for what was in reality a substantive decision. The opinion can be read to suggest that the Court believed the "procedural" due process violation to be the trial court's failure either to issue the defendant's requested instruction to the jury to punish only for the harm done to the plaintiff ${ }^{57}$ or to implement alternative procedures capable of ensuring that the defendant would not be punished for the harm to third parties. ${ }^{58}$ It is surely true that the failure to issue a requested jury instruction can be thought of as a procedural due process violation. ${ }^{59} \mathrm{In}$ circumstances like these, however, doing so only confuses the issue. The failure to give a jury instruction can violate due process only if the defendant has an underlying right to the limitation that the instruction seeks to place upon the jury. That underlying right could be a procedural one, but it could also be a substantive one. For instance, the failure to give an acceptable reasonable doubt instruction in a criminal trial violates procedural due process, ${ }^{60}$ but that is because a criminal defendant has a procedural due process right to a

55. Philip Morris USA v. Williams, 127 S. Ct. 1057, 1067 (2007) (Thomas, J., dissenting); see also $\mathrm{id}$. (Stevens, J., dissenting) (criticizing the majority for boldly "announc[ing] its new rule of substantive law" and for failing to heed the Court's traditional reluctance to expand the substantive due process doctrine).

56. See, e.g., Erwin Chemerinsky, Foreword: The Constitution and Fundamental Rights, 18 U. FLA. J.L. \& PUb. POL'Y, at xi, xii (2007) (describing Williams as a substantive due process case); F. Patrick Hubbard, Substantive Due Process Limits on Punitive Damages Awards: "Morals Without Technique"?, 6o FLA. L. REV. 349, 355-56 (2008); Sheila B. Scheuerman \& Anthony J. Franze, Instructing Juries on Punitive Damages: Due Process Revisited After Philip Morris v. Williams, 10 U. PA. J. CONST. L. (forthcoming 2008) (manuscript at 7 n.28, 54, on file with author), available at http://ssrn.com/abstract=1071073; Douglas W. Kmiec, Up in Smoke: The Supreme Court Loses Its Unanimity, SLATE, Feb. 21, 2007, http://www.slate.com/id/2160286 (describing the majority's invocation of procedural due process as a "legal fig leaf" to cover what was really an indefensible use of substantive due process).

57. See Williams, 127 S. Ct. at 1064 ("It is constitutionally important for a court to provide assurance that the jury will ask the right question, not the wrong one.").

58. See id. at 1065 ("Although the States have some flexibility to determine what kind of procedures they will implement [to protect against punishment for harm to third parties], federal constitutional law obligates them to provide some form of protection in appropriate cases.").

59. See, e.g., Andrew C. Jayne, The Impact of Recent U.S. Supreme Court Punitive Damages Jurisprudence on Oklahoma's Punitive Damages Statute and Jury Instructions, 57 OKLA. L. REV. 873,888 (2004).

6o. See Cage v. Louisiana, 498 U.S. 39 (1990). 
heightened standard of proof. ${ }^{61}$ By contrast, the failure to instruct a jury that, for instance, it must find actual malice before imposing liability on a newspaper for defaming a public official might also be thought of as a procedural due process violation, insofar as an important procedural safeguard-a jury instruction that conforms to the Constitution-was ignored. But the missing instruction was warranted only because the defendant has a substantive free speech right (imposed by the First Amendment and incorporated against the states through substantive due process) to make false statements about the official conduct of public officials in the absence of actual malice. ${ }^{62}$ In such circumstances, the failure to properly charge the jury in reality constitutes a denial of a substantive right, not a procedural one. ${ }^{63}$

The focus on the failure to give the proper jury instruction thus obscures the question of whether Williams was truly grounded in procedural or substantive due process. What ultimately matters is the constitutional source of the underlying right sought to be protected by that instruction - the right not to be punished for the harm done to third parties through an award of punitive damages.

In his dissent, Justice Stevens labeled this new right a "rule of substantive law." ${ }^{64} \mathrm{He}$ did not articulate a basis for that assertion, but there was in fact good reason for it. When the Court previously hinted in Campbell that it might find a constitutional problem with total harm punitive damages, it implied that the constitutional infirmity was a matter of substantive due process. It intimated that the reason why "[d]ue process does not permit courts, in the calculation of punitive damages, to adjudicate the merits of other parties' hypothetical claims against a defendant" is that "[p]unishment on these bases creates the possibility of multiple punitive damages awards for the same conduct." ${ }^{65}$ Unjust multiple punishment for the same conduct is generally understood to be a substantive due process problem - a concern that the piling on will result in excessive cumulative punishment. ${ }^{66}$ It was this substantive concern that seemed to be motivating the Court in Campbell when it first suggested the

61. See In re Winship, 397 U.S. 358 (1970).

62. See N.Y. Times Co. v. Sullivan, 376 U.S. 254, 279-80 (1964).

63. See Time, Inc. v. Hill, 385 U.S. 374, 394-97 (1967) (finding a First Amendment violationnot a procedural due process violation - in the failure to issue an actual malice instruction).

64. Philip Morris USA v. Williams, 127 S. Ct. 1057, 1067 (2007) (Stevens, J., dissenting).

65. State Farm Mut. Auto. Ins. Co. v. Campbell, 538 U.S. 408, 423 (2003).

66. See, e.g., Owens-Corning Fiberglas Corp. v. Malone, 972 S.W.2d 35, 51 (Tex. 1998) (opining that at some "point multiple punitive damages awards arising from the same course of conduct are unconstitutional as a matter of substantive due process"). 
possibility that the Constitution mandates that punitive damages cannot be used to punish the defendant for harm caused to third parties.

But if it was this fear of excessive multiple punishment that motivated the Williams Court-if the dissenters are right that the Court's decision was actually grounded in substantive due process - then the Court's holding is virtually indefensible. If the constitutional infirmity of total harm punitive damages is a substantive one, based on the fact that multiple awards of them can lead to excessive punishment, then they can be unconstitutional only when they are awarded more than once; a single award of total harm punitive damages that accurately punishes the defendant for the full scope of harm caused by its wrongful conduct is not unconstitutionally excessive. ${ }^{67}$

In other words, the fear of excessive multiple punishment does not automatically and categorically amount to a substantive due process violation. Rather, the potential for multiple punishment crosses the threshold of unconstitutionality as a matter of substantive due process only when it leads to actual excessive multiple punishment. Whether that threshold has been crossed in any given case depends on the individual circumstances of that case: the size of the award, the size of the prior awards for the same conduct, whether the jury or the judge has adequately adjusted the current award to take into account the prior awards, and other such factors.

Yet the Court's decision in Williams was categorical. The Williams Court expressly declined to reach the question whether the actual amount of punitive damages awarded to the plaintiff was unduly excessive $;^{68}$ it held only that, regardless of the amount, the punitive award was inherently unconstitutional because it was born of an attempt to punish the defendant for harm to nonparties. Indeed, it would have been virtually nonsensical for the Court to strike down the punitive award in Williams on multiple punishment grounds, given that no allegation was made that the defendant had ever been punished in prior cases for the same wrongful conduct. There had been no multiple punishment at all.

The substantive due process argument is thus untenable. Accordingly, when the Williams Court claimed that it was relying on procedural due process, it must have really meant it (unless its holding was utterly unsupportable). This time, unlike with $B M W$ and Campbell, the accusations of improperly

67. See Colby, supra note 9, at 658-66.

68. See $127 \mathrm{~S}$. Ct. at 1063 ("[W]e shall not decide whether the award here at issue is 'grossly excessive."). $B M W$ and Campbell, by contrast, had found that, even in the absence of multiple punishments, the actual amounts of punitive damages awarded to the plaintiff were unconstitutionally excessive. Campbell, 538 U.S. at 412, 429; BMW of N. Am., Inc. v. Gore, 517 U.S. 559, 585-86 (1996). 
smuggling substantive due process constraints in procedural dressing miss the mark.

\section{B. The Williams Court's Inadequate Basis for Finding a Procedural Due Process Violation}

But was there really a procedural due process violation? ${ }^{69}$ According to the Court, punishing the defendant for harm to nonparties violates procedural due process for two reasons. First, it denies the defendant the opportunity to present individualized defenses with regard to those nonparties; and second, it raises the risk of arbitrariness in the amount of punitive damages because the generalized evidence at trial will not allow the jury to determine precisely the number of victims or the extent or circumstances of their injuries. ${ }^{70}$

69. Along the lines of the jury instruction point just discussed, one could argue that it violates procedural due process to fail to institute some sort of procedural safeguard designed to protect against substantively excessive multiple punishment. See Scheuerman \& Franze, supra note 56, at 7 n.28, 54; cf. W. Union Tel. Co. v. Pennsylvania, 368 U.S. 71, 75 (1961) (noting that a property owner "is deprived of due process of law if he is compelled to relinquish [his property] without assurance that he will not be held liable again . . . in a suit brought by a claimant who is not bound by the first judgment"). In other words, one could argue that even if there was no substantive due process violation on the particular facts of this case, there is an inherent procedural due process violation in the failure to systematically protect against substantive due process violations in cases of this sort. But even if such a failure is itself best viewed as a procedural, rather than a substantive, due process violation, it is difficult to see how it could have formed the basis of the Court's decision in Williams. In Oregon - the state from which the Williams case arose-statute "requires a jury to consider evidence of punishments already imposed on the defendant when it considers the amount of an award of punitive damages.” Williams v. Philip Morris Inc., 92 P.3d 126, 142 (Or. Ct. App. 2004). Thus, according to the Oregon Court of Appeals, the Supreme Court's "concern in [Campbell] about multiple punitive damages awards that would be excessive in total is ameliorated by Oregon law." Id. Whether the requirement to inform the jury of prior awards would indeed be adequate in most cases to ameliorate the potential for multiple punishments to produce substantively excessive awards is certainly debatable. But the Supreme Court in Williams never expressly found this procedural safeguard to be inadequate; indeed, it never discussed it at all. And it would have been highly problematic for the Court to base its decision on these grounds without some showing that the Oregon law in practice has not succeeded in protecting against excessive cumulative punishment. A case in which the Oregon procedural safeguard had not yet even had the opportunity to come into play is hardly the proper vehicle for striking that safeguard down as constitutionally inadequate. One would think that the Court would do so only in a subsequent case in which a jury awarded a massive amount of punitive damages despite having been informed of a prior monumental verdict.

70. See Williams, 127 S. Ct. at 1063. 
As I have previously argued in some detail, these concerns are very real, and they pose a serious risk of unfairness to the defendant in cases of this sort. It can be profoundly unfair to require a defendant to pay punitive damages for wronging thousands of individuals in the absence of evidence sufficient to show that it did, in fact, commit legal wrongs against each of those third parties and without giving it a meaningful chance to defend against those alleged third-party claims. ${ }^{71}$ Still, the Court was too hasty in concluding that these arguments are sufficient in themselves to establish a procedural due process violation. ${ }^{72}$

Let us first consider the Court's secondary concern that "to permit punishment for injuring a nonparty victim would add a near standardless dimension to the punitive damages equation." ${ }^{73}$ The Court asked,

How many such victims are there? How seriously were they injured? Under what circumstances did injury occur? The trial will not likely answer such questions as to nonparty victims. The jury will be left to speculate. And the fundamental due process concerns to which our punitive damages cases refer-risks of arbitrariness, uncertainty and lack of notice-will be magnified. ${ }^{74}$

It is undeniably true that concerns for judicial economy would ordinarily preclude the parties from introducing at trial detailed and individualized evidence as to the specific circumstances of each of the numerous nonparty victims' injuries. But why does punishment in the absence of such evidence rise to the level of a procedural due process violation? That is the key question, and the Court had nothing to say about it; it simply assumed the conclusion - and a questionable one at that. The plaintiff would surely be required, at a minimum, to bring in credible evidence (perhaps in the form of expert testimony or statistical studies) establishing the likely number of victims and the severity of the average injury. Our law has long accepted the fact that even in the criminal law-where due process concerns are at their apex-the magnitude of a sentence for harming large numbers of persons can be calculated through just

71. See Colby, supra note 9, at 592-602, 650-57.

72. This was a question on which I had reserved judgment in my prior article. See id. at 602.

73. Williams, 127 S. Ct. at 1063.

74. Id. 
this type of approximation. ${ }^{75}$ How can it violate due process to calculate civil punitive damages in the same manner?

That leaves the Court's primary concern: that punishing for harm to third parties unconstitutionally deprives the defendant of the opportunity to present individualized defenses related to the alleged nonparty victims. Using the facts of Williams itself as an example, the Court explained that Philip Morris might not actually be liable for many of the harms to other smokers for which it was punished, because many of the other smokers likely did not rely on its fraudulent statements or were fully aware of the dangers of smoking. Those smokers may have been injured by Philip Morris' products, but they were not defrauded by its actions; Philip Morris was not legally responsible for their injuries, and thus there was no warrant for punishing Philip Morris for having wrongfully harmed them. Yet Philip Morris had no opportunity at trial to establish these defenses for each individual victim; there were countless thousands of smokers in Oregon, each of whom had a separate story to tell, and none of whom (except Mr. Williams, through his wife) was before the court to tell it. For this reason, the Court held that Philip Morris was denied its right to due process when the jury punished it for the harm that its products caused to every single in-state smoker. ${ }^{76}$

In the same breath, however, the Court qualified its holding that the defendant cannot be punished for the harm caused to third parties by declaring that the plaintiff can still introduce evidence of such harm, because the fact that others were also harmed shows that the defendant's conduct was particularly reprehensible and warranted higher punitive damages. ${ }^{77}$ As Anthony Sebok explains, this exception is fundamentally inconsistent with the majority's rationale for its primary rule:

The problem with the plaintiffs jury instructions in Philip Morris, according to the Court, was that they allowed the jury to decide whether the defendant had legally harmed smokers who had not sued and whose cases were not properly presented to the jury. But how

75. See, e.g., United States v. Singh, 390 F.3d 168, 192 (2d Cir. 2004) ("A reasonable estimate of the loss [to the many victims] is all that is necessary [to calculate the sentence].”); U.S. SENTENCING GUIDELINES MANUAL $\mathbb{8}$ C2.4 n.2 (2007); see also id. $\$ 2 B 1.1$ n.3(C) (providing that the fine for corporate fraud is calculated by estimating " $[\mathrm{t}]$ he approximate number of victims multiplied by the average loss to each victim," and can even be based on "[m]ore general factors, such as the scope and duration of the offense and revenues generated by similar operations").

76. See Williams, 127 S. Ct. at 1063-64.

77. See id. at 1064 . 
could that problem be cured by an instruction that allowed the jury to enhance its punishment of the defendant for what it did to the plaintiff on the basis of its conduct towards others? Wouldn't that require making a judgment about hypothetical cases-e.g., cases that involved claims of legal wrongs by the defendant in relation to persons who were not part of the case? ${ }^{78}$

Given the exception, the Court's asserted rationale for its decision - that there is a procedural due process deficiency in calibrating punishment by reference to the harm to third parties in the absence of individualized evidence and defenses related to those third parties - cannot explain or justify the Court's holding.

More importantly-even leaving aside the contradiction between the announced exception and the articulated rationale for the rule-the Court's central assertion that it is unconstitutional to punish a defendant for harm to third parties without affording it the opportunity to raise individualized defenses is subject to a foundational objection. Justice Stevens argued in dissent that there was no need to provide Philip Morris with the opportunity to establish defenses related to the peculiarities of other smokers' claims because Philip Morris was not being ordered to compensate those other smokers. "To award compensatory damages to remedy such third-party harm might well constitute a taking of property from the defendant without due process," explained Justice Stevens. ${ }^{79}$ "But a punitive damages award, instead of serving a compensatory purpose, serves the entirely different purposes of retribution and deterrence that underlie every criminal sanction." damages are designed to redress individual wrongs, and therefore the defendant cannot be ordered to pay them without being afforded the opportunity to present every defense that it has to each of those individual allegations of wrongdoing. Punitive damages, on the other hand, are, like criminal sanctions, designed to punish and deter. They have nothing to do with the private, individual wrongs done to the nonparties; rather, they punish the defendant for the public wrong done to all of society. As Justice Stevens argued, "Whereas compensatory damages are measured by the harm the defendant has caused the plaintiff, punitive damages are a sanction for the public harm the defendant's conduct has caused or threatened." 81

78. Anthony J. Sebok, Punitive Damages: From Myth to Theory, 92 IowA L. REV. 957, 999 (2007) (footnote omitted).

79. Williams, 127 S. Ct. at 1066 (Stevens, J., dissenting).

8o. Id.

81. Id. 
Justice Stevens is surely right that there is no due process problem with punishing the defendant for the harm that it did to society as a whole without affording individualized defenses for each and every victim. That is why the criminal law permits a sentence to be calculated on the basis of a rough approximation of the number of people harmed and the average harm to each victim. ${ }^{82}$ When punishing public wrongs, the judicial system does not care whether the defendant would be liable to each and every one of its alleged victims in tort. It cares only that the defendant engaged in reprehensible conduct and that society suffered as a result. There is no constitutional obligation to calibrate the degree of societal harm with individualized precision.

Justice Stevens's argument thus cannot easily be dismissed. If, as Justice Stevens claims, punitive damages punish public wrongs - if he is correct that they are essentially a form of "criminal sanction" ${ }^{83}$ - then a defendant that is forced to pay a rough approximation of total harm punitive damages generally cannot claim that it has been denied the opportunity to present its defenses. It had every opportunity to defend not only against the plaintiff's claim that it committed a private wrong (and was thus liable for compensatory damages), but also against the plaintiff's claim that it committed a public wrong (and was thus liable for punitive damages), and it lost on both accounts. In Williams itself, Philip Morris was in no way hindered from presenting a defense against the allegation that it "acted with malice or has shown a reckless and outrageous indifference to a highly unreasonable risk of harm and has acted with a conscious indifference to the health, safety and welfare of others" - the Oregon standard for liability for punitive damages. ${ }^{84}$ The jury did not buy it; it found, notwithstanding Philip Morris's vigorous defense, that Philip Morris had committed a malicious or reckless wrong upon society that caused or threatened significant harm to the public. It was only after that defense failed that Philip Morris was forced to pay the punitive damages for which the jury found it liable. And those damages were, by definition, designed to punish it for the full scope of the harm that its public wrong caused or threatened to society. As Justice Stevens noted,

$[\mathrm{T}]$ here is no reason why the measure of the appropriate punishment for engaging in a campaign of deceit in distributing a poisonous and addictive substance to thousands of cigarette smokers statewide

82. See supra note 75 .

83. Williams, 127 S. Ct. at 1066 (Stevens, J., dissenting).

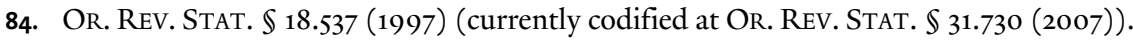


should not include consideration of the harm to those "bystanders" as well as the harm to the individual plaintiff. ${ }^{85}$

The majority's reasoning makes sense only if - contrary to Justice Stevens's assertion-punitive damages are not a form of punishment for public wrongs to society. ${ }^{86}$ For the majority to be correct, Justice Stevens must be incorrect in asserting that the award of punitive damages against Philip Morris was properly intended to serve as "a sanction for the public harm the defendant's conduct has caused." ${ }^{87}$ But Justice Stevens was not going out on a limb in making that assertion. To the contrary, he was simply echoing the conventional judicial wisdom that punitive damages "serve as punishment for what amounts to a public wrong" 88 - punishment "for the wrong committed upon society." 89 As one court recently commented, "The plaintiff remains a party, but the de facto party is our society, and the jury is determining whether and to what extent we as a society should punish the defendant." ${ }^{\circ \circ}$ Indeed, just four years before Williams, the Supreme Court itself had declared that punitive damages "serve the same purposes as criminal penalties," ${ }^{11}$ the very raison d'être of which is, of course, to punish public wrongs on behalf of society..$^{22}$

The Williams majority never directly took issue with the conventional wisdom that punitive damages are punishment for public wrongs. In fact, in

85. Williams, 127 S. Ct. at 1067 (Stevens, J., dissenting).

86. If - contra Justice Stevens - punitive damages punish private wrongs, not public ones, then the Williams majority's constitutional reasoning makes perfect sense. As I have previously explained, it is surely unconstitutional to punish a defendant for a series of individual, private, tortious wrongs without providing evidence that it did indeed commit each alleged private wrong, and without affording the defendant the opportunity to raise individualized defenses for each alleged wrong. See Colby, supra note 9, at 650-57.

87. Williams, 127 S. Ct. at 1066 (Stevens, J., dissenting).

88. Gordon v. State, 585 So. 2 d 1033, 1036 (Fla. Dist. Ct. App. 1991); see also Wayne A. Logan, Civil and Criminal Recidivists: Extraterritoriality in Tort and Crime, 73 U. CIN. L. Rev. 1609, 1610 (2005) ("[L]ike criminal sanctions, punitive damages have come to be viewed as a means to address 'public wrongs' ....”).

89. Buzzard v. Farmers Ins. Co., 824 P.2d 1105, 1115 (Okla. 1991). This was the explicit understanding of the Oregon courts, which helps to explain why the Oregon Supreme Court in Williams did not see a problem with punishing the defendant for harm to nonparties. See DeMendoza v. Huffman, 51 P.3d 1232, 1243 (Or. 2002) ("Oregon courts view[] the punitive and deterrent effect of punitive damages as vindicating interests of society in general, and not of any plaintiff in particular.").

90. Dardinger v. Anthem Blue Cross \& Blue Shield, 781 N.E.2d 121, 145 (Ohio 2002).

91. State Farm Mut. Auto. Ins. Co. v. Campbell, 538 U.S. 408, 417 (2003).

92. See infra Section IV.A. 
declaring that the plaintiff can still introduce evidence of third-party harm, the majority seemed implicitly to agree that punitive damages vindicate the public interest by punishing public wrongs. The Court explained that "[e]vidence of actual harm to nonparties" is admissible because it "can help to show that the conduct that harmed the plaintiff also posed a substantial risk of harm to the general public." ${ }^{93}$ Indeed, declared the Court, even when third parties were not actually harmed, a larger award of punitive damages is justified when the defendant's conduct "nonetheless posed a grave risk [of harm] to the public." 44 Those statements seem to imply that the purpose of a punitive damages award is to redress the wrong to society by punishing the defendant for the harm that it caused - or threatened to cause - to the general public.

The majority opinion thus gives the appearance of theoretical incoherence. The Court's exception is inconsistent with the announced rationale for its rule. And more fundamentally, the conclusion that due process is violated if the defendant is punished for harm to third parties without being able to introduce individualized defenses is dependent on the predicate notion that punitive damages are a form of individualized sanction, rather than a form of punishment for public wrongs; yet the Court reached that conclusion in an opinion that elsewhere suggests that punitive damages are indeed punishment for the harm to the public-for public wrongs.

The Court's reasoning was thus insufficient to justify its holding that punishing the defendant for harm to nonparties violates procedural due process. In fact, that holding cannot be defended without confronting the distinction between public and private wrongs that appears to have eluded the Court. Parts III and IV aim to salvage the Court's holding by doing just that.

\section{PAST: PUNITIVE DAMAGES AS PUNISHMENT FOR PRIVATE WRONGS}

I have previously developed in great detail an argument that, historically, punitive damages - when they were used as a form of genuine punishment served as punishment for private, rather than public, wrongs. ${ }^{95}$ Nineteenthcentury courts were quite explicit in holding that "the damages allowed in a

93. Philip Morris USA v. Williams, 127 S. Ct. 1057, 1064 (2007).

94. Id.; see also id. (approving of the Oregon Supreme Court's observation that the "'jury could consider whether Williams and his misfortune were merely exemplars of the harm that Philip Morris was prepared to inflict on the smoking public at large"” (quoting Williams v. Philip Morris Inc., 127 P.3d 1165, 1175 (Or. 2006))).

95. See Colby, supra note 9, at 613-43. 
civil case by way of punishment[] have no necessary relation to the penalty incurred for the wrong done to the public," but rather are imposed "as a punishment for the wrong done to the individual." ${ }^{96}$ Thus, nineteenth-century case law "makes the distinction between the punishment for the wrong done the public, for which the punishment is inflicted in the criminal action, and that done to the individual, for which punishment may be imposed by the jury in the civil action." 97 As one court explained, "Considered as strictly punitory, the damages are for the punishment of the private tort, not of the public crime." 98 As such, an individual victim was not permitted to punish the defendant for the harm done to society or to nonparties. ${ }^{99}$

Of course, punitive damages have evolved since then. They have come to serve the very different purpose of punishing public wrongs. Justice Stevens was correct in noting that total harm punitive damages - as punishment for public wrongs - are now the norm (or at least they were before the Court perfunctorily struck them down in Williams). But I intend to establish here that, when punitive damages are employed as a form of punishment, the narrow historical conception of punitive damages as punishment for private

96. Hendrickson v. Kingsbury, 21 Iowa 379, 391 (1866) (emphasis omitted).

97. Hauser v. Griffith, 71 N.W. 223, 223 (Iowa 1897).

98. Brown v. Swineford, 44 Wis. 282, 288 (1878).

99. See Colby, supra note 9, at 620-27. Benjamin Zipursky argues that my "history is probably distorted and incomplete" because "punitive damages traditionally served multiple purposes"-not just as punishment for private wrongs. Zipursky, supra note 7, at 143; see also Sebok, supra note 78 , at 1004 ("I have detailed elsewhere at least six different functions that courts attributed to punitive damages in the period examined by Colby ....”). It is certainly true that punitive damages historically served a variety of purposes, as Sebok has masterfully demonstrated. See Anthony J. Sebok, What Did Punitive Damages Do? Why Misunderstanding the History of Punitive Damages Matters Today, 78 CHI.-KenT L. ReV. 163 (2003). That is a point that I at least partially acknowledged in my prior article, see Colby, supra note 9, at 622-29, and Sebok's work makes it even more clear that one cannot distill a single unifying purpose and theory behind the disjointed and often contradictory pastiche of early punitive damages decisions. It was therefore unwise and probably misleading for me to refer on occasion in my prior article to punishment for private wrongs as "the historical conception" of punitive damages. E.g., Colby, supra note 9, at 652 (emphasis added). But the key point for my argument was and is that the courts settled on an understanding of punitive damages as punishment for individual, private wrongs when they confronted the fundamental constitutional questions that surrounded (and still surround) punitive damages - in particular the question of why double jeopardy principles are not violated when a victim is allowed to receive punitive damages for conduct that has already been criminally punished by the state. The courts relied on the notion of punitive damages as punishment for private wrongs as the justification for resolving those questions in favor of the constitutionality of punitive damages. See id. at 620-28. As such, I believe that this notion is the particular historical understanding of punitive damages that matters most in ascertaining their constitutionality - and the constitutional constraints upon them-today. 
wrongs is constitutionally mandated; to employ punitive damages as punishment for public wrongs without affording all of the procedural safeguards that the Constitution would mandate if the same penalty were being sought as a criminal fine violates procedural due process. ${ }^{100}$ That, I submit, is the true reason why imposing punitive damages as punishment for harm to third parties violates procedural due process. And thus, that is the best justification for the result in Williams.

The argument begins by observing that, even in the nineteenth century, the constitutionality of punitive damages was highly dubious. Critics questioned how the Constitution could fairly be interpreted to permit a form of judicially imposed punishment without affording the defendant the benefits of the criminal procedural safeguards mandated by the Fourth, Fifth, Sixth, Eighth, and Fourteenth Amendments (and their state law equivalents). ${ }^{101}$ The best known and most bilious of those many critics, Justice Foster of the New Hampshire Supreme Court, queried,

Why longer tolerate a false doctrine, which, in its practical exemplification, deprives a defendant of his constitutional right of indictment or complaint on oath before being called into court? deprives him of the right of meeting the witnesses against him face to face? deprives him of the right of not being compelled to testify against himself? deprives him of the right of being acquitted, unless the proof of his offence is established beyond all reasonable doubt? deprives him of the right of not being punished twice for the same offence?

100. When I previously took a very cursory (and unsatisfactory) stab at that task, see Colby, supra note 9, at 643-50, my effort was easily mistaken for an essentially originalist argument that "history carries dispositive weight in defining constitutional rights." Zipursky, supra note 7 , at 142-43; see also Sebok, supra note 78 , at 1005 n.213 ("It is an understatement to say that Colby's argument relies on a controversial originalist interpretation of the Constitution.”). As this Part seeks to explain, my argument is not, in fact, originalist. Rather, it is grounded in part in a necessary limitation on the originalist argument that the courts - especially the Supreme Court-have employed in upholding the constitutionality of punitive damages. That is to say, it is the courts that have chosen to defend the constitutionality of punitive damages on purely originalist grounds; the argument here is that, even if one accepts the propriety of an originalist defense, that defense demonstrably does not establish the constitutionality of total harm punitive damages.

101. See, e.g., Lewis Lawrence Smith, Punitive Damages, 41 AM. L. REg. \& REV. 517, 518 (1893) (" $[\mathrm{T}]$ he unfortunate defendant is not only not permitted to ask to have this anomalous crime, for such it amounts to, proved beyond a reasonable doubt, but is denied many other rights accorded to the lowest criminal."). 
Punitive damages destroy every constitutional safeguard within their reach. ${ }^{102}$

When courts confronted these arguments, they rejected them on the lone ground that punitive damages were well established in the law, and a "rule so long and so generally established is a sin against sound judicial principle, not against the constitution." ${ }^{103}$ Even the U.S. Supreme Court relied on the history to deflect these objections. As early as 1851 , the Court wrote, "We are aware that the propriety of this doctrine has been questioned by some writers; but if repeated judicial decisions for more than a century are to be received as the best exposition of what the law is, the question will not admit of argument."104

After the ratification of the Fourteenth Amendment, the Court based its assertion that " $\mathrm{t}]$ he imposition of punitive or exemplary damages in [civil] cases cannot be opposed as in conflict with the prohibition against the deprivation of property without due process of law," and "cannot therefore be justly assailed as infringing upon the Fourteenth Amendment of the Constitution of the United States," on the sole ground that the "propriety and legality [of punitive damages] have been recognized ... by repeated judicial decisions for more than a century." 105

A century later, the constitutional attack on punitive damages resumed. Commentators again charged that punitive damages are unconstitutional because they impose punishment without affording criminal procedural protections. ${ }^{106}$ In 1990, the Supreme Court granted certiorari in Pacific Mutual Life Insurance Co. v. Haslip ${ }^{107}$ to consider, among other questions, whether punitive damages "although nominally civil, must be considered sufficiently criminal in nature ... to entitle [the defendant] to certain protections under

102. Fay v. Parker, 53 N.H. 342, 397 (1873).

103. Brown, 44 Wis. at 282, 288; see also, e.g., Pike v. Dilling, 48 Me. 539, 543 (1861); Duckett v. Pool, 13 S.E. 542,547 (S.C. 1891 ).

104. Day v. Woodworth, 54 U.S. (13 How.) 363, 371 (1851); see also Milwaukee \& St. Paul Ry. Co. v. Arms, 91 U.S. 489, 492-93 (1875) ("[A]lthough some text-writers and courts have questioned its soundness, it has been accepted as the general rule in England and in most of the States of this country.”).

105. Minneapolis \& St. Louis Ry. Co. v. Beckwith, 129 U.S. 26, 36 (1889).

106. See, e.g., Jeffery W. Grass, The Penal Dimensions of Punitive Damages, 12 Hastings Const. L.Q. 241 (1985); Malcolm E. Wheeler, The Constitutional Case for Reforming Punitive Damages Procedures, 69 VA. L. ReV. 269 (1983).

107. 499 U.S. 1 (1991). 
the Fifth and Fourteenth Amendments to the United States Constitution."108 As it had done a hundred years before, the Court rejected that argument on the sole ground that "the common-law method for assessing punitive damages was well established before the Fourteenth Amendment was enacted" and "[n]othing in that Amendment's text or history indicates an intention on the part of its drafters to overturn the prevailing method." ${ }^{109}$ It was only because of "this consistent history"-because " $[\mathrm{t}]$ he Fourteenth Amendment has not displaced the procedure of the ages" - that the Court found no procedural due process violation: "If a thing has been practised for two hundred years by common consent, it will need a strong case for the Fourteenth Amendment to affect it." As Justice Kennedy emphasized in his concurrence, "[T]he judgment of history should govern the outcome in the case before us." 111

Whether or not this historically grounded, originalist defense of the constitutionality of punitive damages is a good one, it remains the only defense that the courts have ever offered to the charge that punitive damages are unconstitutional for failing to provide criminal procedural safeguards. ${ }^{112}$ And,

108. Brief of Petitioner at i, Haslip, 499 U.S. 1 (No. 89-1279). Citing Fay v. Parker, 53 N.H. 342, 397 (1873), quoted above, the Court explained that it granted certiorari "to review the punitive damages procedures and award in the light of the long-enduring debate about their propriety." Haslip, 499 U.S. at 8.

109. Haslip, 499 U.S. at 17-18.

110. Id. (citations omitted). The Court went on to note that it would be "inappropriate to say that, because punitive damages have been recognized for so long, their imposition is never unconstitutional." Id. at 18 . It thus proceeded to consider the fairness of the actual punitive damages award in the case before it. See id. at 18-24. But its basic holding that punitive damages are not categorically unconstitutional despite their failure to provide criminal procedural protections was based solely on their historical pedigree. In Zipursky's words, "the majority opinion comfortably gave presumptive weight to history in its due process analysis." Zipursky, supra note 7, at 114.

111. Haslip, 499 U.S. at 40 (Kennedy, J., concurring). Similarly, the Court's holding in Browning-Ferris Industries v. Kelco Disposal, Inc., 492 U.S. 257 (1989), that the Eighth Amendment's Excessive Fines Clause does not apply to punitive damages was largely grounded in the originalist argument that "the Framers of the Eighth Amendment did not expressly intend it to apply to damages awards made by civil juries." Id. at 273. The Court recognized, in nonoriginalist fashion, that there are some occasions in which the Eighth Amendment should be expanded to cover new punishments not envisioned by the Framers. But this was not one of them: "This aspect of our Eighth Amendment jurisprudence might have some force here were punitive damages a strictly modern creation, without solid grounding in pre-Revolutionary days. But ... [the punitive damages] doctrine was expressly recognized in cases as early as 1763 ." Id. at 273-74.

112. In fact, courts have long suggested that, were it not for history, they would find punitive damages to be unconstitutional. See Colby, supra note 9, at 645-46 (collecting cases). In 1884, the Colorado Supreme Court actually found punitive damages unconstitutional precisely because they punish the defendant without affording the procedural protections of 
for two reasons, it is necessarily dependent on an understanding of punitive damages as punishment for private wrongs.

First, as a matter of both sound logic and sound constitutional reasoning, even if we accept the propriety of originalism, the constitutionality of a current practice can be grounded in its long historical pedigree only if the practice that is being defended today is essentially the same practice that enjoys the long historical pedigree. The Court has, for instance, upheld the constitutionality of obscenity laws in large part on the basis of their long tradition of historical acceptance. ${ }^{113}$ But of course a state could not pass a law redefining "obscenity" to include any speech critical of the Governor and then rely on the cases upholding obscenity bans on historical grounds as an absolute justification for the new law. Even if we accept the basic claim that history justifies exempting obscenity from the rules that would otherwise govern the regulation of speech under the First Amendment, an "obscenity" ban that goes well beyond what was historically encompassed by that term-to an entirely different kind of speech - would have no claim to a valid defense grounded in history simply because it co-opts an old historical label.

The same is true of punitive damages. As I have previously written, the

fact that the historical institution of punitive damages has been around for centuries ... does not ... mean that any remedy that a modern court chooses to call 'punitive damages' is automatically constitutional. If the courts completely change the fundamental nature of the institution of punitive damages, slapping the old label on them will not avoid all questions of constitutional infirmity. ${ }^{114}$

a criminal trial. See Murphy v. Hobbs, 5 P. 119, 120-21 (Colo. 1884). Colorado was a rare state in which the question was still an open one in the late nineteenth century, allowing the court to decide it as a matter of first impression, unencumbered by dubious historical precedents. The court surmised that "[w]ere this subject now presented to the various [other] courts of the country for the first time, we have little doubt as to what the verdict would be." Id. at 120; see also Spokane Truck \& Dray Co. v. Hoefer, 25 P. 1072, 1073-74 (Wash. 1891) (addressing the issue anew, "untrammeled by former decisions," and concluding that, because "many of the time-honored rules governing the trial of criminal actions, and of the rights that have been secured to defendants in criminal actions from the time whereof the memory of man runneth not to the contrary, are absolutely ignored," punitive damages are "repugnant to every sense of justice" (internal quotation marks omitted)).

113. See Roth v. United States, 354 U.S. 476, 484-85 (1957).

114. Colby, supra note 9 , at 647 . 
When the Supreme Court, in the nineteenth century, upheld punitive damages based on their historical pedigree, it understood them to punish "the wrong done to the plaintiff"115 - that is, to be imposed "for the redress of private wrongs." 116 If the courts change the very nature of punitive damages from punishment for private wrongs to individuals to punishment for public wrongs to society, then they can no longer rely on history as an absolute constitutional shield - even if they choose to be originalists.

There is a second, related reason why the historical pedigree defense of the constitutionality of punitive damages is dependent upon the conception of punitive damages as punishment for private wrongs. Why did nineteenthcentury courts declare that punitive damages are punishment for private wrongs? That conception was well grounded in the emerging understanding of the unique nature and role of punitive damages, ${ }^{117}$ but the courts did not coalesce around it or articulate it clearly until they were forced to do so to deflect constitutional attacks - in particular, to deflect the argument that, to avoid unconstitutional double jeopardy, punitive damages should not be allowed where the defendant's conduct was also punished as a crime. The rejoinder to that argument that prevailed in the courts was that there was no double jeopardy violation because the defendant was not being punished twice for the same offense. Each punishment was for a distinct legal wrong-the criminal punishment for the public wrong to society, and the civil punishment for the private wrong to the plaintiff. ${ }^{118}$ "In this view," explained one court, "the awarding of punitive damages can in no just sense be said to be in conflict with the constitutional or common law inhibition against inflicting two punishments for the same offense."119 If punitive damages had been understood at the time as punishment for public wrongs, the courts would have struck them down. ${ }^{120}$

In other words, it was only because punitive damages punished a private wrong legally distinct from the public wrong that is punished by the criminal

115. Day v. Woodworth, 54 U.S. (13 How.) 363, 371 (1851).

116. Mo. Pac. Ry. v. Humes, 115 U.S. 512, 521 (1885).

117. See infra Part IV.

118. See Colby, supra note 9, at 621-22.

119. Hendrickson v. Kingsbury, 21 Iowa 379, 391 (1866); see also, e.g., Zick v. Smith, 112 A. 846, 846 (N.J. Sup. Ct. 1921) (arguing that the double jeopardy argument "is illogical" because the "criminal action is a punishment for the wrong done to the public" whereas the "punitive damages [award] is a punishment for the wrong done to the individual"), affd, 116 A. 927 (N.J. 1922).

120. Indeed, a few courts did just that before the notion of punishment for private wrongs triumphed in punitive damages law. See Colby, supra note 9, at $620 \&$ n.130. 
law - and because they had been around for a long time in that limited formthat the courts historically upheld their constitutionality. History, therefore, provides no basis for upholding the constitutionality of punitive damages conceived, as by the Williams dissent (and perhaps the Williams majority as well), as punishment for public wrongs. And yet history is the only defense that the Supreme Court has ever offered in response to these fundamental constitutional objections.

\section{PRESENT: PROCEDURAL DUE PROCESS AND PUNISHMENT FOR PRIVATE WRONGS}

Of course, it is possible that total harm punitive damages as punishment for public wrongs can continue to stand on firm constitutional footing even after the mistaken crutch of history is pulled out from under them. ${ }^{121}$ But this Part aims to establish that they cannot. And beyond that, it seeks to provide a theoretical justification for the entire notion of punitive damages as punishment for private wrongs - a justification that critics of my prior work have suggested is lacking. ${ }^{122}$ Indeed, some critics have gone so far as to opine that "the concept of a distinct category of 'private' punishment for 'private' wrongs is, at its foundation, incoherent." ${ }^{123}$ This Part seeks to establish that the notion of punishment for private wrongs is not simply a nonsensical and archaic relic of nineteenth-century thinking that we are left to accept, warts and all, if we want to continue to rely on history as a constitutional defense of punitive damages. Rather, it is to this day a sensible and theoretically defensible notion, and it makes sense both conceptually and doctrinally (rather than just historically) to say that punishment for private wrongs-unlike punishment for public wrongs - does not necessitate the provision of criminal procedural safeguards. Cass Sunstein and others have lamented that our "legal culture lacks a full normative account of the relationship between retributive goals and punitive damages." 124 This Part seeks to provide that account. ${ }^{125}$

121. See Comment, Criminal Safeguards and the Punitive Damages Defendant, 34 U. CHI. L. REV. 408,409 (1967) (arguing that the lack of criminal procedural protections can be justified by more than simply "the law's tendency to 'domesticate' its inconsistencies-to accept contradictions simply because it has lived with them for so long”).

122. See, e.g., Sebok, supra note 78, at 1002-04; Zipursky, supra note 7 , at 143.

123. Martin H. Redish \& Andrew L. Mathews, Why Punitive Damages Are Unconstitutional, 53 EMORY L.J. 1, 19 n.9o (2004).

124. Cass R. Sunstein, Daniel Kahneman \& David Schkade, Assessing Punitive Damages (with Notes on Cognition and Valuation in Law), 107 YALE L.J. 2071, 2085 (1998). 
125. The argument in this Part builds upon the important work of Anthony Sebok and Benjamin Zipursky. Sebok and Zipursky have each taken great pains to distinguish their recently promulgated theories of punitive damages from my own (and each other's). See Sebok, supra note 78 , at 1002-o6 (seeking to distinguish his theory of punitive damages as private revenge from my theory of punitive damages as private punishment); id. at 1025-29 (seeking to distinguish his theory from Zipursky's theory of punitive damages as, in part, vindicating a plaintiffs right to be punitive); Zipursky, supra note 7 , at 141-44, 157-58 (seeking to distinguish his theory from mine); $i$. at 147 (seeking to distinguish his theory from Sebok's). But in fact, our theories share a great deal in common. When I say that punitive damages are punishment for private wrongs, I mean precisely that punitive damages are a form of legally sanctioned private revenge, designed to vindicate a plaintiff's legal right to be punitive in a court of law.

Still, while I am deeply indebted to Sebok and Zipursky for adding normative flesh to my bare-bones historical argument, I ultimately agree that, although we arrive at nearly the same place, and although we share many of the same reasons for preferring that place to the alternatives, we take very different routes to get there-and our approaches have very different implications for the future of extracompensatory damages. Sebok and Zipursky fit their accounts into the "civil recourse" theory of tort law. See Sebok, supra note 78, at 102329; Zipursky, supra note 7, at 151-61. So too does John Goldberg, who also defends a vision of punitive damages largely in accordance with the one presented here. See John C.P. Goldberg, Tort Law for Federalists (and the Rest of Us): Private Law in Disguise, 28 HARV. J.L. \& PUB. POL'Y 3, 7 (2004) (arguing that "[w]hat is at stake in [punitive damages] is not [the state's] interest[] in obtaining retribution on behalf of its citizens or in deterring sharp business practices, but the [plaintiffs'] interest in vindicating their rights not to be mistreated in the way that they were," which includes "providing them with satisfaction-a remedy adequate to acknowledge and avenge [the defendant's] predatory conduct towards them"); see also id. at 4 n.2 (citing my work, and particularly Sebok's and Zipursky's, as having "heavily influenced" his "thinking on the subject of punitive damages"). The civil recourse school is premised on the principle that "the animating idea behind our system of tort law" is "that an individual who has been wronged is entitled to an avenue of recourse against the wrongdoer.” John C.P. Goldberg \& Benjamin C. Zipursky, Accidents of the Great Society, 64 MD. L. REV. 364, 402-03 (2005). Thus, Goldberg's and Sebok's arguments that "tort law is not defensible as public regulatory law" are more theoretical than constitutional and are sweeping in their normative scope. Goldberg, supra, at 4. Zipursky's equally sweeping argument includes what may be a constitutional bent, but one that is ultimately unsatisfying. See infra Section IV.C.

My conception of punitive damages as punishment for private wrongs - as legalized revenge-is more in harmony with some normative theories of tort law, such as civil recourse, than others. Indeed, with its emphasis on vindicating the private rights of the plaintiff, it fits comfortably within most corrective justice theories. See, e.g., Richard W. Wright, Right, Justice and Tort Law, in PHILOSOPHICAL FOUNDATIONS OF TORT LAW 159, 175 (David G. Owen ed., 1997) (arguing that the notion of punitive damages as retribution "for the discrete wrong done to a particular individual" accords with corrective justice); see also Mark Geistfeld, Punitive Damages, Retribution, and Due Process, 81 S. CAL. L. REV. 263, 275-84 (2008) (noting that this conception of punitive damages accords with a compensatory theory of tort law). The notion of punitive damages as punishment for private wrongs is seemingly less compatible with utility maximization theories that view tort law primarily in regulatory terms - as serving a collective public interest, rather than the individual private 


\section{A. Punishing Private Wrongs: Private Revenge}

The idea of punitive damages as punishment only for private wrongs might seem at first blush to be counterintuitive and hypertechnical. Most people probably share the instinct of the plaintiff's counsel in Williams, who insisted at oral argument that it makes no sense to suggest that it was inappropriate to punish Philip Morris for the harm done to nonparties because "[p] unitive damages do not punish for harm, they punish misconduct." 126 That is to say, the law punishes a wrongdoer for engaging in wrongful behavior, not for causing harm. Either we punish wrongful behavior, or we do not. The assertion that punitive damages can punish only the private wrong that arises from a wrongful act (the harm to the individual victim), but not the public wrong that arises from that same act (the harm to society), has the ring of proverbial angels dancing on the head of pin. At first, it seems nonsensical, or at least implausibly legalistic, to suggest that tort law can somehow punish only the private aspect of the wrongful act, but not the public aspect. How can the law isolate only one consequence of wrongful conduct for punishment? And in any event, what exactly is the public harm to society other than the harm done to the particular victim - an individual in the public community?

Overcoming these objections requires a deeper exploration of both the nature of private wrongs and the nature of punishment itself.

interest of the plaintiff. See, e.g., Richard A. Posner, Wealth Maximization and Tort Law: A Philosophical Inquiry, in PHILOSOPHICAL FOUndations of TORT LAW, supra, at 99, 100-11. But cf. A. Mitchell Polinsky \& Steven Shavell, Punitive Damages: An Economic Analysis, 111 HARV. L. REV. 869, 948 (1998) (taking into account in economic analysis "the pleasure or satisfaction people obtain from seeing blameworthy parties punished"). Insofar as I see normative value in using punitive damages to punish private wrongs, see infra Section IV.B, I am sympathetic to corrective justice theories in general and to civil recourse in particular. But I am also open to the proposition that tort law can sometimes be employed to serve solely public, regulatory aims; I do not mean to endorse or rely here upon any particular tort theory. My primary argument is that if punitive damages are used as punishment, they must serve as punishment for private wrongs, not public ones. That is fundamentally a constitutional claim, not a theoretical one. As I make clear in Part V, nothing in Williams, or in my own argument, would preclude the use of extracompensatory damages to serve nonpunitive public ends of the type sought by those whose tort theories focus on utility maximization rather than corrective justice. Thus, the argument in this Article is perfectly consonant with a pluralist vision of tort law as serving many different ends. See, e.g., Calabresi, supra note 23; Bruce Chapman, Pluralism in Tort and Accident Law: Toward a Reasonable Accommodation, in PHILOSOPHY AND THE LAW OF TORTS 276 (Gerald J. Postema ed., 2001); Izhak Englard, The Idea of Complementarity as a Philosophical Basis for Pluralism in Tort Law, in Philosophical Foundations OF TORT LAW, supra, at 183.

126. Transcript of Oral Argument at 29, Philip Morris USA v. Williams, 127 S. Ct. 1057 (2007) (No. 05-1256). 


\section{The Nature of Private Wrongs}

As Judge Richard Posner has explained, "Crimes and torts frequently overlap. In particular, most crimes that cause definite losses to ascertainable victims are also torts: the crime of theft is the tort of conversion; the crime of assault is the tort of battery - and the crime of fraud is the tort of fraud." ${ }^{127}$ Yet this overlap does not create redundancy. The tort and the crime arise from the same wrongful act, but they are distinct legal wrongs, invading the rights of separate victims. ${ }^{128}$ The tort is a private wrong to the individual victim; the crime is a public wrong to society. In William Blackstone's classic formulation,

private wrongs, or civil injuries, are an infringement ... of the civil rights which belong to individuals, considered merely as individuals; public wrongs, or crimes and misdemeanors, are a breach and violation of the public rights and duties, due to the whole community, considered as a community, in it's [sic] social aggregate capacity. ${ }^{129}$

If I assault someone, I simultaneously commit a private wrong against him -I cause him pain and humiliation and fear-and a public wrong against society - I disturb the peace and violate the social order. Each of those distinct legal wrongs is redressible in its own way, by its own victim. The wrong to society - the crime-can only be redressed by society's legal representative, the prosecutor, in a criminal prosecution. The wrong to my individual victim - the tort - can only be redressed by the individual victim himself in a civil lawsuit. ${ }^{130}$

Thus, Martin Redish and Andrew Mathews miss the mark when they assert that the distinction between punishment for public wrongs and punishment for private wrongs is "incoherent" because " $[\mathrm{w}]$ hen the state seeks to punish for public wrongs, it is usually doing so to punish and deter harms to private individuals." ${ }^{131}$ It is, of course, true that public wrongs usually (though

127. United States v. Bach, 172 F.3d 520, 523 (7th Cir. 1999).

128. See, e.g., Hutchinson v. Merchs.' \& Mechs.' Bank of Wheeling, 41 Pa. 42, 45 (1861) ("The private wrong was not merged in the public one, nor is the public prosecution intended to supersede the private action. Their purposes are entirely different.”).

129. 4 William BLACKSTONe, COMMENTARIES ${ }^{\star} 5$.

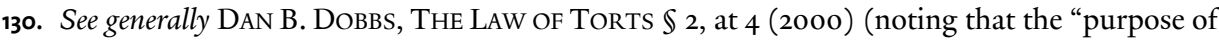
criminal punishment is primarily to vindicate the state's interests" whereas the "purpose of tort liability" is "primarily to vindicate the individual victim and the victim's rights").

131. Redish \& Mathews, supra note 123, at 19 n.90. 
not always) stem from acts that also harm private individuals. But our law insists that the criminal punishment-the punishment for the public wrong arising out of the act, as distinct from the private wrong-is punishment for the harm done to society, not for the harm done to the individual victim. ${ }^{132}$ Blackstone explained that "the king, in whom centers the majesty of the whole community, is supposed by the law to be the person injured by every infraction of the public rights belonging to that community." ${ }^{133}$ In America, the state has replaced the King; a crime - a public wrong - is a wrong against the state alone, as the representative of the community. ${ }^{134}$ Courts have insisted that " $[\mathrm{w}] \mathrm{e}$ must remember that a criminal offense is an offense against the sovereign state, and not against an individual." 135

Of course, in our common parlance, we speak of the individual as the "victim" of the crime, and in our casual thought we tend to think of the criminal law as punishing the defendant for what he did to the individual victim. But that impulse is misleading. In fact, the criminal law punishes the defendant for the harm to society that resulted from his decision to engage in the conduct that hurt the individual victim.

In this regard, my theory has been criticized on the ground that "it is hard to accept that the criminal punishment meted out is only for the public wrong, not the private wrong." ${ }^{136}$ Yet that is the law. The notion that a crime is a wrong to society, not to an individual, and the related notion that the criminal law punishes the defendant only for the wrong to society, not for the wrong

132. See Kenneth Mann, Punitive Civil Sanctions: The Middleground Between Criminal and Civil Law, 101 YALE L.J. 1795, 1806 (1992) ("Within the criminal paradigm, wrongful acts are sanctioned because they are public wrongs, violating a collective rather than an individual interest.").

133. 4 BLACKSTONE, supra note 129 , at ${ }^{\star} 2$.

134. See, e.g., 21 AM. JuR. 2D Criminal Law $\$ 418$ (2008) (“[A] crime is by definition a public wrong, and one against all the people of the state ....”); BLACK'S LAW DICTIONARY 403 (8th ed. 2004) (defining "criminal law" as " $[\mathrm{t}]$ he body of law defining offenses against the community at large").

135. Ex parte Galbreath, 139 N.W. 1050, 1051 (N.D. 1913). This notion traces back to Cesare Beccaria, who insisted that "the true measure of crimes is ... harm to society." CESARE BeCCARIA, ON CRIMES AND Punishments AND Other Writings 24 (Richard Bellamy ed., Richard Davies \& Virginia Cox trans., Cambridge Univ. Press 1995) (1766); see also William F. McDonald, Towards a Bicentennial Revolution in Criminal Justice: The Return of the Victim, 13 AM. Crim. L. ReV. 649, 655 (1976) ("Beccaria took issue with the proposition that the primary purpose of the criminal justice system was to serve as an aid to private action in obtaining redress from the criminal. Since the system arose from a social contract, it should serve the interests of society, not the individual victim." (footnote omitted)). The emergence of this conception of the criminal law is discussed further in Subsection IV.A.3.

136. Zipursky, supra note 7 , at 144. 
done to the individual, is not simply a meaningless legal fiction. It is profoundly important at both the theoretical and practical levels.

When one person assaults or kills or rapes another, that act not only causes tremendous pain to the individual victim, it also makes us all feel less secure. It makes us afraid for our own safety. It harms the unity and the security of the community that we share. That is the public wrong-the wrong that is the business of the criminal law. ${ }^{137}$ "That additional fear confers upon crime its public nature and, arguably, justifies the punitive intervention of the state." ${ }^{138}$ The criminal law is not concerned with the private wrong to the individual victim. ${ }^{139}$

To illustrate this point, consider a case like Eacret $v$. Holmes,${ }^{140}$ in which the court denied standing to the parents of a murder victim who sought to preclude a governor who was morally opposed to the death penalty from commuting the sentence of their son's killer. The court explained that, even though the parents naturally "should feel more deeply upon the subject than other members of the general public," the criminal punishment was not being imposed for their (or their son's) benefit any more than for the benefit of anyone else:

Punishment for crime is not a matter of private vengeance, but of public policy. Any violation of constitutional rights which might be supposed to flow from what is asserted to be an 'unconstitutional' exercise by the executive of the pardoning power would affect equally all the people of the state, rather than the plaintiffs in a different and special way. ${ }^{141}$

Another illustration of this point can be found in the black-letter rule that, because the crime consists of the public wrong to society, not the private wrong

137. See, e.g., Robert Nozick, ANARchy, State, AND Utopia 67 (1974) (distinguishing crime from tort on the ground that the former induces fear in the general public).

138. George P. Fletcher, A Transaction Theory of Crime?, 85 COLUM. L. ReV. 921, 925 (1985).

139. See id. (rejecting a theory of crime that "treats the criminal harm as the violation of a single person's interest in not suffering the involuntary loss of his entitlements," because that theory fails to recognize that "criminal harms are not merely private and thus limited to the victim, but public in their impact"); McDonald, supra note 135, at 650 ("Crime is now conceived of entirely in terms of an offense against society. The damage to the individual victim is incidental and its redress is [not] regarded as a function of the criminal justice process." (footnote omitted)); see also supra notes 129-135 and accompanying text.

140. 333 P.2d 741 (Or. 1958).

141. Id. at 743 . 
to the victim, it is not up the individual victim to determine whether to pursue (or abandon) a criminal prosecution.

Because a crime is by definition a public wrong against the State, it is not usually an acceptable defense that the person wronged by a criminal has condoned the offense. Neither repayment of the victim nor settlement between the defendant and victim will constitute a bar to conviction of the offender. ${ }^{142}$

This notion goes back at least as far as Cesare Beccaria, who explained that the "right to have someone punished does not belong to any individual; it is the right of all the citizens and of the sovereign. The individual can give up his part of this right, but he cannot cancel that of others." ${ }^{143}$

Indeed, a public wrong can occur even in the absence of an individual victim. If a person drives drunk and is fortunate enough not to cause an accident, she does not commit a tort; there was no individual victim of her dangerous conduct, and thus no private wrong. But she still commits a crime; her conduct has violated the social contract, made us all less secure, and threatened harm to society. ${ }^{144}$

In sum, a private wrong is a tort. It is legally distinct from a public wronga crime - even when both wrongs arise out of the very same act, and even when an individual injury stands at the heart of the crime. And when the criminal law punishes the public wrong (the crime), it does not punish the defendant for having committed the private wrong (the tort), and it does not vindicate any personalized interest that the individual victim might have in punishing the defendant that is distinct from the interest that all of society has in seeing the defendant punished. ${ }^{145}$

142. Pratt v. State, 307 S.E.2d 714, 716 (Ga. Ct. App. 1983).

143. BECCARIA, supra note 135 , at 75 .

144. See, e.g., DobBS, supra note $130, \mathbb{2}$, at 5 ("Criminal law redresses the state's interests in the security of society. It may punish conduct that threatens those interests even when no harm has been done. Speeding increases risks to others and so may be punished criminally. Tort law, aimed at protection of individuals, would never impose liability for speeding alone; tort law would impose liability only if harm results.").

145. The traditional absence of the individual victim's interest from the criminal law may be slowly eroding. The recent move toward including restitution as part of the criminal sentence is obviously concerned with the victim's interests. See, e.g., United States v. Ferranti, 928 F. Supp. 206, 221 (E.D.N.Y. 1996) (noting that the emergence of restitution in American criminal law has challenged the traditional view that criminal "[o]ffenses were thought of as crimes against society, rather than against the individual"). But restitution is about compensation, not punishment. As Judge Posner has explained, including restitution 


\section{Punishment and Compensation in Criminal and Civil Law}

Our legal system draws a fundamental distinction between punishment and compensation. Compensation is concerned with making the victim whole, whereas punishment is concerned with making the perpetrator suffer. ${ }^{146}$ And our legal system generally proceeds from the assumption that punishment is the proper remedy for a public wrong, whereas compensation is the proper remedy for a private wrong. Prosser and Keeton give the hornbook rule: "The purpose of [a criminal] proceeding is to protect and vindicate the interests of the public as a whole, by punishing .... The civil action for a tort, on the other

in the criminal case essentially tacks on a private tort suit to a criminal proceeding in the interest of judicial economy. See United States v. Bach, 172 F.3d 520, 523 (7th Cir. 1999). It does not necessarily reconceptualize the criminal offense as one against the individual victim. The broader victims' rights movement, by contrast, does indeed represent an effort to reconceptualize the criminal law as engaged (at least in part) in the business of private vengeance - punishing the private wrong. See, e.g., Susan R. Klein, Redrawing the CriminalCivil Boundary, 2 BUfF. CRIM. L. REV. 679, 689 (1999) (arguing that the victims' rights movement seeks "to transform a proceeding that is supposed to be about a wrong to society into a proceeding about the harm to ... individual private victims"); Doug Janicik, Note, Allowing Victims' Families To View Executions: The Eighth Amendment and Society's Justifications for Punishment, 61 OHIO ST. L.J. 935, 973 (2000) (“[S]tate legislatures, under the disguise of the victims' rights movement, have endorsed a private form of vengeance...."); $i d$. ("While the penal system wants to ensure the criminal gets his just deserts' for violating the law and moral standards that define our community, the victim's family wants revenge only for its injury."). This movement has found some success in reforming the criminal law. See Jennifer Gerarda Brown, The Use of Mediation To Resolve Criminal Cases: A Procedural Critique, 43 EMORY L.J. 1247, 1248-49 (1994) (discussing the growth in victim-offender mediation programs); Robert C. Davis, Barbara Smith \& Susan Hillenbrand, Restitution: The Victim's Viewpoint, 15 JUST. SYS. J. 746, 748-50 (1992) (discussing the federal Victim and Witness Protection Act and the use of restitution in state courts); Erin Ann O'Hara, Victim Participation in the Criminal Process, 13 J.L. \& POL'Y 229, 241 (2005) (discussing state victims' rights amendments and statutes). But it certainly has not yet succeeded in changing the very nature of criminal sanctions. See Mark S. Umbreit et al., Restorative Justice: An Empirically Grounded Movement Facing Many Opportunities and Pitfalls, 8 CARDOZO J. CONFLICT RESOL. 511, 514 (2007) (noting that in our legal system, crime is still "viewed as having been committed against the state," but offering restorative justice (the notion upon which the victims' rights movement is based) as a "very different way of understanding and responding to crime" that "recognizes crime as being directed against individual people" rather than "viewing the state as the primary victim in criminal acts"); see also Jordan J. Ballor, To Reform or To Abolish? Christian Perspectives on Punishment, Prison, and Restorative Justice, 6 AVE MARIA L. REV. 481, 511 (2008) ("[A]dvocates of restorative justice agree that the status quo of criminal justice needs to be altered.”).

146. See Gail Heriot, An Essay on the Civil-Criminal Distinction with Special Reference to Punitive Damages, 7 J. CONTEMP. Legal Issues 43, 47-48 (1996). 
hand, is commenced and maintained by the injured person, and its primary purpose is to compensate for the damage suffered." 147

Against this background, it may seem odd to suggest that punitive damages punish private wrongs. If private wrongs are, by definition, wrongs that call for compensation, not punishment, and if civil suits are, by definition, suits that seek compensation, not punishment, then punishment for private wrongs in a civil lawsuit appears to be nonsensical.

That is, indeed, exactly what nineteenth-century critics argued. In the colorful words of the New Hampshire Supreme Court:

How could the idea of punishment be deliberately and designedly installed as a doctrine of civil remedies? Is not punishment out of place, irregular, anomalous, exceptional, unjust, unscientific, not to say absurd and ridiculous, when classed among civil remedies? What kind of a civil remedy for the plaintiff is the punishment of the defendant? The idea is wrong. It is a monstrous heresy. It is an unsightly and an unhealthy excrescence, deforming the symmetry of the body of the law. ${ }^{148}$

Modern critics have continued to sound this theme that " $[\mathrm{p}]$ unitive damage awards corrupt the distinction between the civil and criminal law." ${ }^{149}$ As Prosser and Keeton wrote, punitive damages appear "anomalous" insofar as "the ideas underlying the criminal law have invaded the field of torts." 150

The problem here is more than just one of asymmetry and anomaly. It is one of constitutionality and procedural fairness. When the criminal courts punish, they do so only after providing the procedural protections of the criminal law. The Constitution tolerates nothing less. But when civil courts punish, they do so without affording any of those safeguards. Thus, the most fundamental of all questions surrounding punitive damages is how it can be constitutional for courts to administer them as punishment without criminal procedural safeguards. As noted above, that concern has long formed the heart

147. W. Page Keeton et al., Prosser and Keeton on the Law of Torts $₫$ 2, at 7 (5th ed. 1984) [hereinafter Prosser \& KeETON].

148. Fay v. Parker, 53 N.H. 342, 382 (1873).

149. L.S. (Bob) Carsey, The Case Against Punitive Damages: An Annotated Argumentative Outline, 11 FORUM 57, 58 (1975).

150. Prosser \& Keeton, supra note $147, \mathbb{2}$, at 9. For a sophisticated argument that this invasion is theoretically unjustifiable, see Ernest J. Weinrib, Punishment and Disgorgement as Contract Remedies, 78 CHI.-Kent L. REV. 55, 86-93 (2003). 
of the argument that punitive damages are unconstitutional. ${ }^{151}$ In David Owen's words, the lack of criminal procedural safeguards in the assessment of punitive damages "assures that controversy and debate follow such assessments wherever they may roam, as surely as summer follows spring." 152

This Article suggests a resolution to the controversy-one that stems from the distinction between punishing public and private wrongs. As a matter of both theory and law, there is a profound difference between the two, and that difference explains why criminal procedural safeguards are not necessary for punitive damages that punish the defendant only for the harm caused to the plaintiff.

\section{Public Retribution and Private Revenge}

To explain the theoretical difference between punishment for public wrongs and punishment for private wrongs, it is helpful to step back into the past, when there was no difference between the two. In Anglo-Saxon times, legal proceedings to redress wrongs were initiated by individuals, not the state. ${ }^{153}$ The remedies that were recoverable in those proceedings were intended both to punish the wrongdoer and to compensate the victim. ${ }^{154}$ They were revenge and compensation rolled into one. ${ }^{155}$

The common law, however, quickly developed a sharp distinction between punishment and compensation. The writ of trespass (a precursor to the modern civil tort action) was the vehicle by which a victim could seek compensation. Punishment, by contrast, was achieved through the appeal of felony, a legal action privately initiated by the victim that was essentially criminal in nature. ${ }^{156}$ Through the mechanism of the latter action, the legal system relied primarily on the individual victim to impose punishment on the

151. See supra Part III.

152. David G. Owen, A Punitive Damages Overview: Functions, Problems and Reform, 39 VILL. L. REV. 363, 366 (1994).

153. See Anthony J. Sebok, Introduction: What Does It Mean To Say that a Remedy Punishes?, 78 CHI.-Kent L. ReV. 3, 3-4 (2003).

154. See id.; Emily Sherwin, Compensation and Revenge, 40 SAN DIEGO L. REV. 1387, 1397-1400 (2003).

155. See Sherwin, supra note 154 , at 1399 (noting that, in addition to being compensatory, the Anglo-Saxon wergeld system "served, at least in part, as a civilized substitute for violent revenge" and "can be viewed as entailing revenge in a more civilized form").

156. See David J. Seipp, The Distinction Between Crime and Tort in the Early Common Law, 76 B.U. L. REV. 59, 83-86 (1996). 
wrongdoer. ${ }^{157}$ As Lawrence Friedman explains, in England, "there was no such thing as a 'district attorney,' that is, a paid official whose job was to prosecute crime on behalf of the state." ${ }^{158}$ Rather, individual victims "were supposed to prosecute on their own-and at their own expense." England, the responsibility for criminal prosecution was placed upon the victim, rather than the state. ${ }^{160}$

These private criminal actions were motivated by a desire for revenge, rather than a desire for compensation. ${ }^{161}$ Legal historian David Seipp explains that medieval "[1] awyers named vengeance as the motive for bringing appeals of felony." ${ }^{162}$ These actions were "instruments of vengeance." ${ }^{163}$ Seipp notes that the historical sources "attest to powerful feelings of vengeance on the part of ... victims," and explains that the "motive of vengeance was more readily understood and accepted in the Middle Ages than it is now. The church taught that vengeance was a virtue and sometimes a duty." 164 Indeed, explains Seipp, "[i]f courts of law had not provided a means of seeking vengeance, victims would more readily have resorted to bloodfeuds, cycles of retaliation that would escalate and last for generations." ${ }^{165}$ As the English historian J.F. Stephen famously declared, "The criminal law stands to the passion of revenge in much the same relation as marriage to the sexual appetite." 166

Accordingly, as crime and tort emerged as distinct branches of the common law, the distinction between the two initially did not turn on the identity of the prosecutor; both actions were privately prosecuted by the individual victim. Nor did it turn on whose interests were being served; both actions satisfied the

157. See John D. Bessler, The Public Interest and the Unconstitutionality of Private Prosecutors, 47 ARK. L. ReV. 511, 515 (1994); Seipp, supra note 156, at 61-72.

158. LAWRENCE M. Friedman, CRIME AND PUNishment in AMERICAN History 29 (1993).

159. $I d$. at 29.

160. See Juan Cardenas, The Crime Victim in the Prosecutorial Process, 9 HARV. J.L. \& PUB. POL'Y 357, 359-66 (1986).

161. See 1 James Fitzjames Stephen, A History of the Criminal LaW of England 245 (photo. reprint 1996) (London, MacMillan \& Co. 1883) (“[T]he private vengeance of the person wronged by a crime was the principal source to which men trusted for the administration of justice in early times."); Bessler, supra note 157 , at 515 ("According to . . historians, private prosecutions developed in England as a means of facilitating private vengeance.").

162. Seipp, supra note 156 , at 63 .

163. $I d$. at 78 .

164. $I d$. at 63 .

165. Id. at $63-64$

166. James Fitzjames Stephen, General View of the Criminal LaW of England 99 (photo. reprint 2005) (London, Macmillan 1863). 
private interests of the victim. Rather, the distinction lay in the victim's motive for bringing the lawsuit and the remedy sought: "The crux of the distinction between crime and tort in the early common law was the choice of vengeance or compensation." 167 Victims who preferred compensation could bring an action for a writ of trespass; victims who preferred vengeance could bring an appeal of felony. "They could either put their wrongdoers to death and collect nothing [through an appeal of felony], or collect money for themselves and leave their wrongdoers alive with the rest of their wealth intact [through a writ of trespass]." 168

Gradually, over the period from the thirteenth to the sixteenth century, the primary method of prosecuting crimes shifted from criminal actions brought by the victims to criminal actions brought by the Crown - that is, indictments of felony. ${ }^{169}$ These publicly prosecuted criminal actions, unlike their privately prosecuted predecessors, were not designed or understood to serve the goal of vengeance. ${ }^{170}$ Rather, they were brought to vindicate the peace of the community. Seipp explains that "the king punished felons because every subject wanted or should want them punished. The king's peace was their peace. A felon to the king was a felon to the whole kingdom. Robbery and fighting offended the whole community, not just the individual victim." ${ }^{171}$ This was the emergence of the distinction between punishing public wrongs and punishing private wrongs. As the identity of the prosecutor changed, the goal of the criminal law changed along with it-from securing individual revenge to vindicating and protecting the public peace. ${ }^{172}$ Thus emerged the modern rule

167. Seipp, supra note 156 , at 84 .

168. Id.

169. See id. at $72-73$.

170. See id. at 73 ("Lawyers did not describe the king's motive for prosecuting felons as a desire for vengeance.").

171. Id. at 74 .

172. See also, e.g., Brown, supra note 145 , at 1254-55; Davis et al., supra note 145 , at 746 ("As time passed, a distinction was gradually drawn between offenses against the social order (crimes) and offenses between individuals (civil wrongs). In the former cases, the state replaced victims as the wronged party in criminal proceedings."). Here in America, privately initiated criminal prosecutions lingered longer. See Brown, supra note 145, at 1255; William F. McDonald, The Role of the Victim in America, in Assessing the Criminal: Restitution, Retribution and the Legal Process 295 (Randy E. Barnett \& John Hagel III eds., 1977) (noting that many criminal prosecutions in colonial America were perceived as redressing an individual injury and were privately prosecuted). Thus, during the colonial era, "criminal law was a combination of both public and private prosecution." Rachel King, Why a Victims' Rights Constitutional Amendment Is a Bad Idea: Practical Experiences from Crime Victims, 68 U. CIN. L. REV. 357, 367 (2000). And some of those privately prosecuted actions may have afforded the possibility of simultaneously attaining both revenge and compensation. See 
that the victim, even if he chooses to forgive the wrongdoer, does not have the authority to end a criminal prosecution. ${ }^{173}$ That was the opposite of the rule that had governed privately initiated criminal prosecutions by appeal of felony: because those actions were designed to vindicate the victim's desire for revenge, not the king's peace, wrongdoers who obtained royal pardons "could not use them to avoid sentences of death on appeals brought by victims." 174 Thus, by the dawn of the modern era, private vengeance had fallen out of both the civil law, which had by this time long been concerned with compensation alone, ${ }^{175}$ and the criminal law, which was now concerned with the peace of the public community. ${ }^{176}$

Yet the desire for revenge burns bright in the human heart - too bright for the law to ignore. ${ }^{177}$ The common law thus found a new outlet for revenge:

McDonald, supra note 135 , at 652-53. By the early nineteenth century, however, the English notion that crimes are public wrongs to society, rather than private wrongs to individuals, had taken root in America as well, and privately initiated prosecutions fell into disuse. See Brown, supra note 145 , at 1255.

173. See Seipp, supra note 156 , at $78-79$.

174. Id. at 79 .

175. See Sherwin, supra note 154 , at 1400 (" $[\mathrm{P}]$ rivate remedies became a vehicle for redressing losses...."). Emily Sherwin argues that the Anglo-Saxon roots of compensatory damages as a stylized form of revenge are still felt in some aspects of compensatory damages doctrine - that "some aspects of modern compensatory remedies suggest that the law still provides an outlet for the impulse toward personal revenge.” Id.; see also Marc Galanter \& David Luban, Poetic Justice: Punitive Damages and Legal Pluralism, 42 AM. U. L. Rev. 1393, 1406 (1993) (noting that many plaintiffs seek compensatory damages in part "for purposes of vengeance, retribution, or vindication"). Be that as it may, compensatory damages are designed and calibrated to compensate, not to facilitate revenge.

176. The Wisconsin Supreme Court explained,

In an early day in England private parties prosecuted criminal wrongs which they suffered. They obtained an indictment from a grand jury, and it became the duty and the privilege of the person injured to provide a prosecutor at his own expense to prosecute the indicted person. Our scheme of government has changed all this. It is now deemed the better public policy to provide for the public prosecution of public wrongs without any interference on the part of private parties, although they may have been injured in a private capacity different from the general public injury that accrues to society when a crime is committed. So under our system we have private prosecution for private wrongs and public prosecution for public wrongs.

State v. Peterson, 218 N.W. 367,369 (Wis. 1928).

177. See, e.g., Ellis COSE, BONE TO PICK 68 (2004) (opining that the "impulse to revenge appears to be hardwired in humans, a result of our evolutionary development"); Kenworthey Bilz, The Puzzle of Delegated Revenge, 87 B.U. L. Rev. 1059, 1063 (2007) (citing psychological and biological studies showing that the urge for revenge is universal, cutting across cultures, and indeed appears to be present even in nonhuman primates); Richard A. Posner, Retribution 
punitive damages. It is important to note that not all private wrongs - not all torts - can give rise to punitive damages. Historically, punitive damages were allowed only for certain kinds of torts: those that violated the dignity of the victim by insulting or humiliating her. ${ }^{178}$ Sebok explains that, over time, the category of private wrongs giving rise to punitive damages expanded, but it has remained limited to wrongs that "express[] a lack of respect [for] the victims similar to that expressed by an act of insult or humiliation," such as fraud, or a crass corporate decision to place profits over a known risk of harm to consumers. ${ }^{179}$ For wrongs such as these-where the defendant has added insult to injury-compensation is not enough. Victims want revenge. ${ }^{180}$

That is what punitive damages give them. Punitive damages vindicate the dignity of an individual victim by allowing her to punish the defendant for committing a humiliating or insulting tort upon her. When full compensation is not enough, when the plaintiff also demands to see the defendant suffer for what he did to her-demands to punish him for what he did to her-she seeks punitive damages. Punitive damages are legally sanctioned private revenge. ${ }^{181}$

and Related Concepts of Punishment, 9 J. LEGAL STUD. 71, 79 (1980) (noting the "vengeful component in our genetic makeup").

178. See Dorsey D. Ellis, Jr., Fairness and Efficiency in the Law of Punitive Damages, 56 S. CAL. L. ReV. 1, 14-15 (1982); Sebok, supra note 78, at 1007-15. Despite Sebok's suggestion to the contrary, see Sebok, supra note 78, at 1006-08, my prior work emphasized both that the "vindication of the dignity of the victim was the whole point of punitive damages, which, it will be recalled, were initially imposed only in cases involving insult or affront to the honor and dignity of the victim," Colby, supra note 9, at 634-35, and that,

properly understood in reference to their historical roots, these damages are based in the victim's right to seek punishment for the private, individualized insult to her personal honor and dignity. That right - the interest sought to be protected by punitive damages - is intensely private. It would make no sense to allow a third party with no relationship to the victim to vindicate it.

Id. at 651 (citations omitted); see also id. at 615, 629-37 (noting that "punitive damages were initially awarded exclusively in cases that involved an insult to the honor and dignity of the victim”). Still, Sebok skillfully develops these points well beyond what my prior work had done.

179. Sebok, supra note 78 , at 1011-15.

180. " $[\mathrm{T}]$ he motivation for revenge is triggered by a transgression of the worth or dignity or respect of someone.” Peter A. French, The Virtues of Vengeance 87 (2001).

181. On this fundamental point, I am in agreement with Sebok and Zipursky. See Sebok, supra note 78 ; Zipursky, supra note 7 , at 154 (noting that there is a "quality of vengefulness to punitive damages"). Other commentators have also made this observation in passing. See, e.g., Owen, supra note 152 , at 375 (referring to punitive damages as a "kind of private revenge"); Sherwin, supra note 154, at 1402 (suggesting that punitive damages are a form of "private punishment" that serve the goal of private revenge); Note, Exemplary Damages in the Law of Torts, 70 HARV. L. REV. 517, 521 (1957) ("Many plaintiffs seeking exemplary 
Once we understand that fact, it is worth inquiring whether "punitive" damages are misnamed. Is the satisfaction of private revenge really a form of punishment? One could argue that it is not. "Getting even" is, after all, a metaphor of compensation. Following the reasoning of Jean Hampton, one could posit that a victim who suffers insult - in Hampton's terminology "moral injury" - has been "diminished" by the wrongdoer who fails to recognize and respect the victim as a person of equal moral worth. ${ }^{182}$ The victim thus demands vindication: she wants her moral worth "repaired" by forcing the defendant to suffer a loss that reequalizes their moral statuses. ${ }^{183}$ In this respect, punitive damages ensure that the victim is made whole again not only financially, medically, and emotionally (which is where compensatory damages stop), but also morally. The only way to make the victim truly whole is to allow her to punish the defendant. Only then has her moral status-her honor-been reestablished. To Hampton, this "is actually a form of compensation to the victim." 184

Perhaps it is. But even so, it is also punishment. ${ }^{185}$ If the only way to achieve full compensation is to allow the plaintiff to impose punishment, then it is difficult to deny that the additional remedy is punitive, even if it is also in some nontraditional sense "compensatory." It is a familiar refrain of punitive damages law that punitive damages are designed to go further then mere compensation for insult or humiliation. "Such damages," say the hornbooks, "are given to the plaintiff over and above the full compensation for the injuries,

damages are motivated to some extent by a desire to revenge themselves on the defendant.").

182. Jean Hampton, Correcting Harms Versus Righting Wrongs: The Goal of Retribution, 39 UCLA L. REV. 1659, 1666, 1677 (1992).

183. Id. at 1686-87. For an excellent discussion of vengeance as a form of equalization of honor in primitive societies, see WILLIAM IAN MILLER, EYE FOR AN EYE (2006).

184. Hampton, supra note 182 , at 1698 ; see also Galanter \& Luban, supra note 175 , at 1432-33; Owen, supra note 152, at 378; Sebok, supra note 78, at 1019-20.

185. See, e.g., Kennedy v. Mendoza-Martinez, 372 U.S. 144, 189 (1963) (Brennan, J., concurring) (observing that "naked vengeance" is " "punishment' in the purest sense"); LEO ZAIBERT, PUNISHMENT AND RETRIBUTION 69-95 (2006) (articulating a detailed philosophical argument that revenge is a kind of punishment). Of course, one could invest a great deal of energy wrestling with epistemological questions about the nature of punishment, but I am inclined to agree with Marc Galanter and David Luban that it suffices for these purposes to define punishment as simply the "deliberate imposition of a harm, injury, deprivation, or other bad thing on someone on the ground of the commission of some offense." Galanter \& Luban, supra note 175 , at 1397 ; $c$. H.L.A. Hart, Prolegomenon to the Principles of Punishment, 6o Proc. Aristotelian Soc'Y 1, 4 (1959) (defining punishment as the imposition by the legal system of unpleasant consequences upon an offender for an offense against legal rules). 
for the purpose of punishing the defendant." ${ }^{186}$ As Arthur Ripstein explains, "Although the victim suffered an additional dignitary loss, and the punitive damages serve to address that loss, their purpose is not to compensate for it. Indeed, their point is precisely that the dignitary loss is not compensable. They serve instead to vindicate the right." ${ }^{187}$

Punitive damages are indeed punishment. But despite the Supreme Court's ill-considered dicta to the contrary, ${ }^{188}$ they are a type of punishment that serves an entirely different goal from the one served by the criminal law. ${ }^{189}$ The punishment of public wrongs through the criminal law is a world apart from the punishment of private wrongs through punitive damages. ${ }^{190}$

Because it is seeking to vindicate a different wrong, the state, acting on behalf of society, has an interest in punishment that differs from that of the individual victim. The state's interest might be seen as deterrence-if it fails to punish the offender, it encourages him to act again and others to follow in his footsteps, placing us all at greater risk in the future. The state's interest might also be seen as retribution. Public retribution is typically conceived of in two competing ways: as a mechanism for preserving equal liberty, and as a system of ensuring just deserts.

The former vision, as Dan Markel explains, conceives of retribution by the state as effectuating society's commitment to equal liberty. By committing a criminal act, an offender effectively signals that he believes he has greater liberty than his fellow citizens - those whom he victimizes for his own gain. ${ }^{191}$ " $[\mathrm{T}]$ he offense is an active rebellion against the political order of equal liberty

186. PROSSER \& KeETON, supra note $147, \mathbb{2}$ 2, at 9.

187. ARThur RipStein, EQUALITY, ReSPONSIBILITY AND THE LAW 151 (1999). Sebok explains that " $[\mathrm{v}]$ indication is obviously not the same thing as compensation, although one could imagine how, under certain circumstances, the act of vindication might provide, at the same time, compensation for feelings wounded through insult." Sebok, supra note 99, at 200.

188. See, e.g., State Farm Mut. Auto. Ins. Co. v. Campbell, 538 U.S. 408, 417 (2003) (declaring that punitive damages "serve the same purposes as criminal penalties").

189. See Geistfeld, supra note 23, at 1099 ("Retribution and deterrence can have different meanings in tort law and criminal law, contrary to the Court's assumption that these two purposes are shared by the two bodies of law.").

190. Cf. Sebok, supra note 78, at 1017 (articulating "two kinds of punishment: retribution in public law and revenge in private law"). Zipursky makes a similar point when he argues that "it is the plaintiff's right to be punitive, not the system's need to punish the defendant, that explains the special status of punitive damages within American tort law." Zipursky, supra note 7 , at 107. The plaintiff's right to be punitive is the private right to seek revenge. The system's need to punish the defendant is the public interest in retribution.

191. See Dan Markel, State, Be Not Proud: A Retributivist Defense of the Commutation of Death Row and the Abolition of the Death Penalty, 40 HARV. C.R.-C.L. L. REV. 407, 430-31 (2005). 
under law. ${ }^{192}$ By punishing him, the state is vindicating society's collective interest in restoring and reinforcing the social order.

The competing vision of retribution in the criminal law is based not on the notion that society must vindicate the rule of law and equal liberty, but rather on the principle of just deserts: society has a moral obligation to punish culpable wrongdoers to the extent of their desert. ${ }^{193}$ As John Rawls explains, "It is morally fitting that a person who does wrong should suffer in proportion to his wrong doing.... [A]nd the severity of the appropriate punishment depends on the depravity of his act." 194

Under either view of the nature and role of public retribution, it is clear that the retribution that the government seeks for the public wrong is conceptually distinct from the retribution that the individual victim seeks for the private wrong-revenge. ${ }^{195}$ "Formal retributive punishment," explains Emily Sherwin, "is inflicted in the name of the community for transgressions of its common standards.... In contrast ... revenge is based on personal grievance arising from an injury to the avenger or someone close to him." ${ }^{196}$ Robert Nozick has carefully distinguished public retribution from private revenge. Nozick's distinction is based on several characteristics, including:

192. Id. at 433 .

193. See, e.g., Michael Moore, Placing Blame: A General Theory of the Criminal LaW 91, 153-54 (1997).

194. John Rawls, Two Concepts of Rules, 64 PHIL. Rev. 3, 4-5 (1955).

195. "[R] evenge is personal retribution." CHARLEs K.B. BARTON, GETTING EVEn: REvenge AS A FORM OF JUSTICE 12 (1999). It differs from public retribution, whether the latter concept is understood as the imposition of just deserts, see, e.g., JefFrie G. MURPHY, GetTIng Even 17 (2003) (distinguishing revenge from a retribution of just deserts on the ground that " $[\mathrm{t}]$ he goal of vengeance is simply to provide vindictive satisfaction to victims, and victims may require for their satisfaction something other than ... what wrongdoers deserve"), or as a guarantor of equal liberty, see Markel, supra note 191, at 437-40 (explaining how an equal liberty vision of "retributive justice might usefully be contrasted with revenge"); see also G.W.F. Hegel, Elements of the Philosophy of Right \$220, at 252 (Allen W. Wood ed., 1991) (arguing that revenge vindicates the victim's private interest, whereas a criminal prosecution vindicates the public's universal interest in justice).

196. Sherwin, supra note 154 , at 1409 ; see also FRENCH, supra note 180 , at $67-68$ (noting that revenge, unlike retribution, is personal); Posner, supra note 177 , at 72 ("While retribution focuses on the criminal's wrong, [revenge] focuses on the impulse of the victim (or of those who sympathize with him) to strike back at the criminal."). But see OLIVER WENDELL Holmes, JR., THe COMmON LAW 45 (photo. reprint 2008) (1881) (arguing that retribution is simply "vengeance in disguise"); SUSAN JACOBY, WILD JUSTICE 4 (1983) (arguing that "retribution" is "a word that affords the comfort of euphemism although it is virtually synonymous with 'revenge"). 
Retribution sets an internal limit to the amount of the punishment, according to the seriousness of the wrong, whereas revenge internally need set no limit to what is inflicted. ...

$\ldots$ Revenge is personal ... [w]hereas the agent of retribution need have no special or personal tie to the victim of the wrong for which he exacts retribution. ...

$\cdots$

... Revenge involves a particular emotional tone, pleasure in the suffering of another, while retribution either need involve no emotional tone, or involves another one, namely, pleasure at justice being done....

...

... There need be no generality in revenge ... [w]hereas the imposer of retribution, inflicting deserved punishment for a wrong, is committed to general principles mandating punishment in other similar circumstances. ${ }^{197}$

Criminal law theorists have generally focused on the importance of keeping revenge out of the criminal law. ${ }^{198}$ No civilized government employs its

197. Robert Nozick, Philosophical Explanations 367-68 (1981). To this list, Markel adds that retribution, unlike revenge, necessarily depends on the use of the power of the state and concerns itself with the moral autonomy, dignity, and rehabilitation of the offender. See Markel, supra note 191, at 438 .

198. See, e.g., Geoffrey Scarre, After Evil: Responding to Wrongdoing 115 (2004) (noting that most "retributivist thinkers... have wished to disconnect as fully as possible the notions of justice and revenge"); Aaron Xavier Fellmeth, Civil and Criminal Sanctions in the Constitution and Courts, 94 GEO. L.J. 1, 24 (2005) (rejecting "revenge as an appropriate justification for punishment in a liberal democracy"); Lynne N. Henderson, The Wrongs of Victim's Rights, 37 STAN. L. REV. 937, 994 (1985) (noting that "retaliation has received relatively little support from philosophers or social scientists"). One occasionally sees references to an outlier theory of retribution in the criminal law that sounds in notions of "revenge." But the use of the label "revenge" in this context is misleading. This theory sees criminal punishment as vindicating a very different interest from the one served by punitive damages as punishment for private wrongs. One version of this theory views the criminal law as achieving revenge on behalf of society for the public wrong visited upon society. See Henderson, supra, at 991 (noting that even if criminal retribution is viewed as revenge, rather than moral desert, it is societal revenge, because "[s]ociety has a right to retaliate against those who have hurt it or failed to follow its rules"); Sherwin, supra note 154 , at 1409 n.93 (noting that "even formal retribution may involve collective revenge for an act that harms society as a whole"). If the criminal law plays that role, it still redresses a collective, societal wrong, rather than an individual, private wrong.

A related version of this theory focuses on the impulse that we all have to get back at the perpetrator of a particularly brutal crime, even if we have no personal connection to the 
prosecutorial authority to help its citizens to extract a pound of flesh from those who have wronged them. As George Fletcher puts it, criminal punishment must not be about vengeance, but rather "must maintain its public character. It is not purely a private institution. It is imposed in the name of the People or State against actions that threaten the well-being of the entire society." 199

Punitive damages, on the other hand, are all about private vengeance. They are an entirely different animal. ${ }^{200}$ For this reason, I respectfully but forcefully disagree with the claim of Redish and Mathews that "the concept of a distinct category of 'private' punishment for 'private' wrongs is, at its foundation, incoherent." Criminal punishments and punitive damages are neither

victim. See Bilz, supra note 177 , at 1071 (citing scientific studies demonstrating that "people derive satisfaction not only from foiling and avenging wrongs against themselves but foiling and avenging wrongdoing generally"). If criminal punishment is understood to satisfy that impulse, then it could be seen as redressing wrongs to individuals, not wrongs to society. But it still does so on behalf of the public, not the victim; it still vindicates the collective interest of the community in avenging the wrong, not the private, personal interest of the victim. See Fellmeth, supra, at 23 ("[T]he fundamental value that the legal system promotes under the revenge motive [for criminal punishment] ... is the psychological gratification of the public."); cf. Polinsky \& Shavell, supra note 125, at 948 (arguing in utilitarian terms that "the punishment objective derives ultimately from the pleasure or satisfaction people obtain from seeing blameworthy parties punished"). Even if one articulates this as an "individual vengeance rationale for criminal punishment," Paul Boudreaux, Booth v. Maryland and the Individual Vengeance Rationale for Criminal Punishment, 80 J. CRIM. L. \& CRIMINOLOGY 177, 178 (1989) (emphasis added) (calling for "an individual-oriented 'vengeance' rationale for criminal punishment, based on the observed visceral satisfaction felt by individuals in society as the result of seeing a criminal punished for his crime"), it is premised on "[a]ggregated individual vengeance" - the collective vengeance of all of the individuals in society, rather than the vengeance of the victim alone-as the justification for the criminal law, see id. It does not seek to use the criminal law to vindicate the unique and personal interest of the victim. As such, it is not truly revenge. The natural impulse to avenge wrongs to others is best labeled as "vigilantism," rather than "vengeance" or "revenge." BARTON, supra note 195, at 79. Revenge, as Nozick observed, is personal; it is not the business of the criminal law.

199. GeOrge P. FletCher, BASIC CONCEPTS OF CRIMINAL LAW 39 (1998); see also French, supra note $18 \mathrm{o}$, at 68 ("The state does not punish the criminal for the sake of revenge, though it can, depending on the penal theory one adopts, punish for the sake of retribution.").

200. David Owen has recognized the distinction between private revenge and public retribution, but he concludes (wrongly, in my opinion) that punitive damages do and should serve to advance both interests. See Owen, supra note 152, at 375-77.

201. Redish \& Mathews, supra note 123 , at 19 n.9o. In this same vein, I reject Zipursky's characterization of my view as based on the idea that "punitive damages [are] punishment in the same sense as criminal punishment, only attached to a more narrowly defined act (a 'private wrong')." Zipursky, supra note 7 , at 158 . It is not the "act" that distinguishes criminal and civil punishment; to the contrary, the same "act" often leads to both types of 
redundant nor indistinguishable, even if they are both imposed as a consequence of the same wrongful act. They are distinct punishments for distinct legal wrongs serving distinct punitive goals.

\section{B. The Desirability of Punishing Private Wrongs}

But is private revenge a legitimate goal in our legal system? To be sure, revenge is a ubiquitous theme in popular culture, most visibly in western and action hero movies. ${ }^{202} \mathrm{We}$, the viewers, find ourselves rooting for the wronged character seeking revenge, and we celebrate when he finally achieves it at the end-the colder served the better. We crave revenge in our hearts. But our pleasure is a guilty one; in our heads, we tend to view revenge as unhealthy and primitive. ${ }^{203}$ And thus we tend to believe that revenge should be purged from a legal system that cherishes reason over passion. ${ }^{204}$ As Francis Bacon long ago exclaimed, "Revenge is a kind of wild justice; which the more man's nature runs to, the more ought law to weed it out."205

We have a good reason for that impulse: "revenge as a motive for action has no necessary connection with justice." ${ }^{206}$ The avenger does not necessarily

punishment. The distinction is based, rather, on the legal wrong being punished and the goal of the punishment.

202. See, e.g., FRENCH, supra note 180 , at 3-64.

203. See, e.g., BARTON, supra note 195, at xiv ("Especially in contemporary Western societies, revenge is widely thought of as being crazy, nasty, and unworthy of the aspirations of truly civilized people, or of a civilized society. . . . Seeking justice is all very well, but it is far from acceptable for anyone to admit that the justice they claim to seek may in fact add up to revenge."); JACOBY, supra note 196, at 12 (noting that the "contemporary psychiatric approach to the question of revenge" is that "the urge to retaliate may be universal but it is unhealthy" and thus people should give it up and rely instead on the detached retribution of the criminal process).

204. See, e.g., Guido Calabresi, The Costs of Accidents 298 (1970) (suggesting that the notion that "the victim - or his family - has the right to see that retribution is exacted ... smacks ... of revenge," which is a "not very healthy urge to get even"); Bruce Chapman \& Michael Trebilcock, Punitive Damages: Divergence in Search of a Rationale, 40 ALA. L. REV. 741, 787 (1989) ("Retribution must not be replaced by privately motivated revenge ...."); Note, supra note 181, at 522 ("A modern legal system can hardly be based on revenge ...."). Leah Mervine observes that the word "vengeance" does not even appear in Black's Law Dictionary. Leah R. Mervine, Comment, Bridging the "Philosophical Void" in Punitive Damages: Empowering Plaintiffs and Society Through Curative Damages, 54 BUFF. L. REV. 1587, 1627 n.250 (2007). Nor does “revenge.” BLACK'S LAW DiCTIONARY, supra note 134.

205. Francis Bacon, Of Revenge, reprinted in 6 COLLECTED WORKS OF FrANCIS BACON pt. 2, at 384 (Routledge/Thoemmes Press 1996) (1625).

206. SCARRE, supra note 198 , at 101. 
care whether the punishment fits the crime. ${ }^{207}$ Nor does he necessarily care whether like cases are treated alike. ${ }^{208}$ Nor is he likely to provide his target with a fair opportunity to explain himself-to establish his innocence, to present evidence of mitigating circumstances, or the like. Vengeance cares not for justice. As such, it seems incompatible with law.

But these problems with revenge are tied to its extralegality. ${ }^{209}$ If we control revenge through the legal system - through the mechanism of judicially constrained punitive damages - we can ensure that it is achieved in a way that is consistent with, not defiant of, law and justice. We can ensure that the punishment fits the offense, that like cases are treated alike, and that the accused is treated fairly. ${ }^{210}$

In fact, allowing controlled revenge affirmatively serves the goal of justice. Given the powerful, instinctive human impulse for revenge, affording a legal outlet for revenge within the framework of justice helps to prevent victims from seeking revenge outside of the framework of justice. As Holmes noted, because "people would gratify the passion of revenge outside of the law, if the law did not help them, the law has no choice but to satisfy the craving itself, and thus avoid the greater evil of private retribution." 211 Indeed, one of the earliest justifications for punitive damages offered by the courts was that their availability would deter insulted victims from seeking private revenge outside of the law. ${ }^{212}$

207. See Hegel, supra note 195 , $\ 102$, at 130 ; NozICK, supra note 197 , at 367 ; Fellmeth, supra note 198, at 25; Posner, supra note 177 , at 82 (noting "a serious deficiency in a simple vengeance approach to punishment" - that " $[\mathrm{t}]$ here is nothing in the concept of vengeance ... that suggests a limitation on the magnitude of retaliation").

208. See NOZICK, supra note 197 , at 368 .

209. See BARTON, supra note 195 , at 42 ("[J] ust like any other kind of punishment, retribution, including personal retribution, which is revenge, can be just or unjust depending on whether the principles of justice, such as proportionality and not punishing the innocent, are observed or violated.”).

210. See, e.g., MURPHY, supra note 195 , at 20 (discussing Aeschylus's Oresteia trilogy, in which the impulse for private revenge outside of the law is productively transformed into "the pursuit of revenge under the constraints of law").

211. HOLMES, supra note 196, at 41-42; see also, e.g., COSE, supra note 177 , at 73 ; Owen, supra note 152 , at 375 .

212. See, e.g., Alcorn v. Mitchell, 63 Ill. 553, 554 (1872); Merest v. Harvey, (1814) 128 Eng. Rep. 761,761 (C.P.) (Heath, J.) ("It goes to prevent the practice of duelling, if juries are permitted to punish insult by exemplary damages."). 
What is more, even beyond its ability to stave off extralegal private revenge, there is much to be said for allowing private revenge within the law. ${ }^{213}$ That is to say, revenge is not simply an unavoidable evil that is at least less odious when cabined within the law; it in fact serves a legitimate interest that the law might actively pursue. Allowing punitive damages as punishment for private wrongs vindicates the dignity of the victim. ${ }^{214}$ Sebok explains that when a tortfeasor has committed a wrong that insults the victim's dignity, "the defendant violated at least two rights: The primary private right (to physical security, property, etc.) and the right to be treated as someone deserving to have those primary private rights respected by others." 215 Compensatory damages redress the violation of the first right, but not the second one. The criminal law, which is concerned only with the interests of society, redresses neither. ${ }^{216}$ The violation of the second right can be redressed only through punitive damages, which allow the victim to equalize her moral status with that of her aggressor. ${ }^{217}$ Marc Galanter and David Luban refer to this feature of punitive damages as "expressive defeat"-a public announcement of moral equality to counteract the message of inferiority that the tortfeasor sent to, and about, the victim by humiliating her without regard to her honor or her right

213. This point has been made by a number of theorists who seek a greater role for revenge in the criminal law. See, e.g., BARTON, supra note 195, at xvi (arguing that, "far from revenge being an alternative to justice, when implemented with appropriate legal and institutional constraints, revenge is a perfectly legitimate and sometimes superior form of justice"); FRENCH, supra note 180 , at 112-229 (articulating a detailed philosophical argument that revenge is morally legitimate-indeed, virtuous - so long as it meets the conditions of being pursued by an appropriate person, being imposed upon a person who deserves it, and being proportional to the offense); Steven Eisenstat, Revenge, Justice and Law: Recognizing the Victim's Desire for Vengeance as a Justification for Punishment, 50 WAYNE L. REV. 1115, 1119 (2004) (" $[\mathrm{I}] \mathrm{t}$ is not immoral for a victim to want to punish his offender so as to cause his offender to suffer; and that punishment which causes suffering is also just, so long as it is inflicted upon the party guilty of the offense, and is proportional to the level of harm suffered by the victim.").

214. See Colby, supra note 9, at 634; $c f$. Jerome Hall, Interrelations of Criminal Law and Torts: II, 43 Colum. L. Rev. 967, 977 (1943) (explaining that, unlike a criminal punishment, a punitive damages award "is an authoritative vindication of the injured person's rights").

215. Sebok, supra note 78 , at 1014.

216. But see RIPSTEIN, supra note 187 , at 148 (arguing that criminal punishment redresses the second right).

217. See Hampton, supra note 182, at 1686-87. Thus, Roscoe Pound once remarked that punitive damages were appropriate because the defendant "acted as if the [plaintiff] had no right to be considered." Gostkowski v. Roman Catholic Church of the Sacred Hearts of Jesus \& Mary, 186 N.E. 798,799 (N.Y. 1933). 
to be treated as a morally worthy human being in possession of rights that are entitled to respect. ${ }^{218}$

Revenge thus has value, so long as it takes place within the confines of the law. Still, given the existence of the criminal law, it is worth asking whether punitive damages are necessary to gain the benefits of revenge. Yes, the criminal law technically vindicates society's interests, rather than the individual victim's ${ }^{219}$ but most victims do not know that. In an important recent article, Kenworthey Bilz observes that victims often view the criminal law as serving the goal of equalizing their social standing and moral worth with that of the offender. ${ }^{220}$ That is to say, victims are willing to "delegate" their revenge to the criminal prosecutor. ${ }^{221}$

If that is so, then perhaps there is no need for punitive damages. ${ }^{222} \mathrm{I}$ am inclined to disagree, however, for two reasons. First, the law cannot have it both ways. The law cannot simultaneously defend retributive criminal justice against charges that it is nothing more than glorified revenge $\mathrm{e}^{223}$ on the ground that it in fact serves a very different purpose, while at the same time dismissing the need for punitive damages on the ground that the criminal law adequately serves the purpose of facilitating revenge.

Second, as a functional matter, the criminal law often does not adequately substitute for private revenge. Bilz notes many circumstances in which victims are not willing to delegate their revenge to the state, or are not satisfied with the results when they do. ${ }^{224}$ In fact, explains Bilz, victims are least willing to step aside in favor of the state when they are the victims of crimes in which their honor has been besmirched. ${ }^{225}$ Yet those are precisely the wrongs that call

218. See Galanter \& Luban, supra note 175 , at 1432-38. Galanter and Luban appear to view punitive damages as serving both the individual interest in equalizing moral status through expressive defeat and the public interest in public retribution. On my theory, they are half right.

219. See, e.g., Ex parte Galbreath, 139 N.W. 1050, 1051 (N.D. 1913) (explaining that it is the "sovereign state ... whose dignity, alone, is sought to be vindicated" by the criminal law).

220. Bilz, supra note 177 , at 1088-90.

221. See id. at 1063-64.

222. See Ellis, supra note 178 , at 29 (noting that punitive damages may be unnecessary to placate "the victim's desire for vindication or vengeance" because the criminal law provides an alternative).

223. See, e.g., Furman v. Georgia, 408 U.S. 238, 343 (1972) (Marshall, J., concurring) ("Punishment as retribution has been condemned by scholars for centuries, and the Eighth Amendment itself was adopted to prevent punishment from becoming synonymous with vengeance." (citations omitted)).

224. Bilz, supra note 177 , at 1100-11.

225. Id. at 1100-05. 
for punitive damages. ${ }^{226}$ In addition, because regulatory agencies and prosecutors are subject to capture and governmental prosecutorial resources are limited, the criminal law will often fail to go after wrongdoers, especially the rich and the well-connected. ${ }^{227}$ And often, even when it does go forward with a criminal prosecution, the government will fail to obtain a conviction, thus leaving the victim unsatisfied. ${ }^{228}$ The entire modern victims' rights movement is fueled by the reality that victims are routinely left unsatisfied by the criminal process, particularly by their inability to play a central, decision-making role in the quest for punishment; their desire for revenge, or at least for a fair shot at pursuing revenge within the confines of the law, is not met. ${ }^{229}$

\section{Constitutionality: Private Revenge and Criminal Procedure}

When properly circumscribed, punitive damages are thus a desirable feature of our legal system. But are they constitutional? Benjamin Zipursky notes that punitive damages present something of a "constitutional puzzle": " $[\mathrm{I}] \mathrm{n}$ a legal system that regularly cautions against elevating form over substance, it is peculiar that there has been near-immunity [from constitutional scrutiny] for what are openly labeled forms of 'punishment." "230

That puzzle deepens when we recognize that the prevailing judicial understanding of punitive damages in recent years has been Justice Stevens's view of punitive damages as punishment for public wrongs. The Supreme Court has expressed "concerns" with the risk of unfairness that arises as a result of the fact that "defendants subjected to punitive damages in civil cases have not been accorded the protections applicable in a criminal proceeding." ${ }^{231}$ And it has cautioned that " $[\mathrm{g}]$ reat care must be taken to avoid use of the civil

226. See supra notes 178-179 and accompanying text.

227. See Dan Markel, Retributive Damages: A Theory of Punitive Damages as Intermediate Sanction, 94 CORNELL L. ReV. (forthcoming 2009) (manuscript at 53-58, on file with author), available at http://papers.ssrn.com/sol3/papers.cfm?abstract_id=991865.

228. Of course, punitive damages plaintiffs are often unsuccessful too, and thus fail to obtain the revenge they seek. But at least they have the satisfaction of being given the opportunity to pursue their revenge in a legal action initiated and controlled by them. Cf. Christopher J. Robinette, Peace: A Public Purpose for Punitive Damages?, 2 Charleston L. Rev. 327, 337-38 (2008) (noting that punitive damages are uniquely able to quell the victim's desire for revenge because of their personal nature-because the victim is empowered to bring and control the action).

229. See Eisenstat, supra note 213 , at 1144.

230. Zipursky, supra note 7 , at 106.

231. State Farm Mut. Auto. Ins. Co. v. Campbell, 538 U.S. 408, 417 (2003). 
process to assess criminal penalties that can be imposed only after the heightened protections of a criminal trial have been observed, including, of course, its higher standards of proof." ${ }^{232}$ "Punitive damages," it insists, "are not a substitute for the criminal process." ${ }^{233}$ But if they "serve the same purposes as criminal penalties," 34 then how are they not simply a "substitute for the criminal process?" The Court has never answered that question.

Seeking to develop a sophisticated account of the concept of punitive damages as punishment for public wrongs, Dan Markel articulates and defends a vision of punitive damages as vindicating the public interest in precisely the same way that the criminal law does. ${ }^{235}$ Explicitly distinguishing them from revenge, ${ }^{236}$ he views punitive damages as "a scheme of retributive justice committed to condemning misconduct in the public's name, rather than the victim's." ${ }^{237} \mathrm{He}$ thus describes punitive damages as the state's "outsourcing" of its prosecuting function to private parties. ${ }^{23}$ Punitive damages, he claims, "allow[] private parties to vindicate the kinds of wrongs the criminal system might, in a fully-funded world, pursue." 239

But Markel's proposition would seem to make punitive damages a "substitute for the criminal process." 240 Is it really that easy to get around the Constitution's mandate of heightened procedural safeguards in criminal cases? $?^{241}$ The Supreme Court has observed that " $[t]$ hose who wrote our Constitution ... intended to safeguard the people of this country from

232. Id. at 428 .

233. $I d$.

234. Id. at 417 .

235. Markel, supra note 227 , at 48, 6o. To Markel, punitive damages serve the "public's interest in retributive justice." $I d$. at 6 .

236. $I d$. at $24-25$.

237. Id. at 48 .

238. $I d$. at 65 .

239. Id. at 61; see also In re Sch. Asbestos Litig., 789 F.2d 996, 1003 (3d Cir. 1986) (noting that punitive damages "awards act almost as a form of criminal penalty administered in a civil court at the request of a plaintiff who serves somewhat as a private attorney general"); Galanter \& Luban, supra note 175, at 1445; Michael L. Rustad, Happy No More: Federalism Derailed by the Court that Would Be King of Punitive Damages, 64 MD. L. REV. 461, 528-31 (2005).

240. State Farm Mut. Auto. Ins. Co. v. Campbell, 538 U.S. 408, 428 (2003).

241. Markel views punitive damages as an "intermediate sanction," necessitating greater procedural protections than compensatory damages, but fewer than criminal penalties. See Markel, supra note 227 , at 11 n.48. He plans to address constitutional concerns in an upcoming work. See id. at 8 n.20, 67 (citing Dan Markel, How Should Punitive Damages Work?, 157 U. PA. L. REV. (forthcoming 2009)). 
punishment ... unless certain tested safeguards were observed," such as the burden of proof beyond a reasonable doubt, the privilege against selfincrimination, and the right to be free from double jeopardy. ${ }^{242}$ If the government can simply "outsource" its prosecuting function to private individuals who are not constrained by those procedural safeguards, then the Bill of Rights becomes a largely optional constraint-one that the government can easily, and would often gladly, circumvent. ${ }^{243}$ Indeed, Galanter and Luban profess that one advantage of punitive damages over criminal punishment is that the lower standard of proof in civil trials ensures that more defendants will lose their cases. ${ }^{244}$

Again, how can that be constitutional? Zipursky's answer appears to be that punitive damages have a "double aspect": they simultaneously play the civil, private law role of affording the victim a private "right to be punitive," and the criminal, public law role of satisfying the public's need for retribution and deterrence. ${ }^{245}$ That is to say, punitive damages are simultaneously punishment for both public and private wrongs. Zipursky argues that if the private aspect of punitive damages were to be abandoned, then they would become unconstitutional. But so long as a punitive damages award is in some amorphous way tied to the civil aspect of the private right to be punitive, it is constitutional for the jury to impose punishment that is also based on the criminal aspect of public retribution and deterrence; the fact that punitive damages are self-consciously serving criminal goals is constitutionally acceptable so long as they are also serving civil goals. ${ }^{246}$

That conclusion is hard to accept. If our concern is with sanctions that serve criminal law goals without criminal procedural safeguards, then the fact that punitive damages also serve the individual's interest in being punitive-in private revenge-should hardly matter. The death penalty also serves the victim's family's interest in exacting private revenge, but that does not mean that it can be imposed on behalf of society without regard to the constraints demanded by the Bill of Rights. ${ }^{247}$

242. United States v. Lovett, 328 U.S. 303, 317 (1946).

243. See Chapman \& Trebilcock, supra note 204, at 804-05 (arguing that, if the government "contracts out" its prosecutorial function to private parties through punitive damages, then criminal procedural protections should be provided).

244. See Galanter \& Luban, supra note 175 , at 1443.

245. Zipursky, supra note 7 , at 155-59.

246. See id. at 155-56, 164-65, 168.

247. Sebok criticizes Zipursky along similar lines. See Sebok, supra note 78, at 1027. 
Zipursky attempts to ameliorate this objection by stating that a punitive damages award that is larger than what "a reasonable juror could have concluded the plaintiff was entitled to in light of the wrong the defendant did to her," or that otherwise cannot be "properly regarded as reflecting a judgment about the plaintiff's right to be punitive," is unconstitutional for failure to provide criminal procedural safeguards. ${ }^{248}$ That suggests that, at the end of the day, the punitive damages award must be defensible solely as a punishment for the private wrong; if it can be defended only by reference to its criminal aspect, then it is unconstitutional. ${ }^{249}$ Still, Zipursky's account suggests that it is permissible to instruct the jury on the basis of the criminal aspect of punitive damages, so long as the size of the verdict can ultimately be defended as a civil punishment. Williams essentially rejects that assertion-that it is constitutional to instruct the jury that it can punish for the harm done to society, so long as, ultimately, the size of the punitive award would be defensible as punishment only for the harm done to the plaintiff-and for good reason. The claim that punitive damages have a "double aspect" is an insightful descriptive account of the Court's schizophrenic jurisprudence, but it is not a constitutional defense of it. If punitive damages possess a "criminal aspect" - if the legal system seeks to use them to pursue the goals of the criminal lawthen their constitutionality remains suspect regardless of whether they also have a "civil aspect."

So we must return once again to the fundamental question: How is it constitutional to punish a defendant in the absence of criminal procedural protections? The answer, I believe, is that it is not-unless the punishment is meted out solely for the private wrong, not the public one. Substantiating that assertion necessitates at least a brief exploration of the notoriously murky boundary between the civil and the criminal law. Any foray into this territory is bound to be unsatisfying. As one commentator has explained, "Despite this importance, the Court's numerous decisions in the area have amounted to an incoherent muddle. Indeed, one would be hard-pressed to identify an area of constitutional law that betrays a greater conceptual incoherence." ${ }^{250}$ Still, I

248. Zipursky, supra note 7 , at 168 (emphasis omitted).

249. In this regard, Zipursky seems at times to reject the legitimacy of the very "double aspect" of punitive damages that he describes. If an award of punitive damages is unconstitutional if it goes beyond the civil aspect to the criminal one, then it would seem that only the civil aspect is permissible. See id. at 107 ("Insofar as punitive damages are basically civil, and not about criminal punishment, they do not merit the special constitutional scrutiny afforded to criminal defendants. Insofar as they are criminal, they do merit such scrutiny.").

250. Wayne A. Logan, The Ex Post Facto Clause and the Jurisprudence of Punishment, 35 AM. CRIM. L. REV. 1261, 1268 (1998); see also Fellmeth, supra note 198, at 9-10 (describing the Court's 
believe that enough of an answer can be teased from the doctrinal and conceptual morass.

Over the years, commentators and courts have offered numerous proposals for delineating the boundary between civil and criminal law. This is not the place to recount and analyze them all. Suffice it to say that no proposal is obviously correct, and indeed it may well be that there is no perfect answer to be found. Perhaps there is less of a clear line than a spectrum, from the wholly civil on one side, through a sliding scale of hybrid actions, to the wholly criminal on the other. In fact, much of the current debate rages over the question of whether there is or should be a set of "middle ground" sanctions that are neither completely civil nor completely criminal in nature. ${ }^{251}$

I take no position here on that question. I seek only to offer a sensible understanding of the ultimate line across which lies the purely criminal law, and thus the crossing of which necessitates the provision of criminal procedural safeguards. And I seek to offer a sensible explanation of how it is that punitive damages can be said not to cross that line.

This explanation is one that existing proposals have trouble providing. Consider two of the most promising possibilities. First, Galanter and Luban argue that a sanction can be criminal only if the prosecuting party is the state, rather than a private individual. ${ }^{252}$ That line might explain why punitive damages do not warrant criminal procedural protections. But it is conceptually problematic, especially when it comes to punitive damages. Galanter and Luban defend their line on the ground that the Bill of Rights is premised on the "fear [of] the power of the state .... to eliminate its political enemies," and they assert that "these special concerns do not really implicate punitive damages." 253 The conclusion, however, does not follow from the premise. Zipursky explains,

Galanter and Luban treat private plaintiffs as those to whom the state has delegated enforcement power-in effect, as private attorneys

decisions in this area as "nothing less than a jurisprudential Frankenstein's monster," and "as incoherent as any in the Court's jurisprudence").

251. Compare Mann, supra note 132 (arguing for the explicit recognition of middle ground sanctions), with Carol S. Steiker, Punishment and Procedure: Punishment Theory and the Criminal-Civil Procedural Divide, 85 GEO. L.J. 775 (1997) (arguing against intermediate sanctions).

252. See Galanter \& Luban, supra note 175 , at 1456.

253. Id. at 1457; see also Klein, supra note 145, at 691 (arguing that punitive damages fall on the civil side of the line because "the framers wished to protect individuals from the government, not from private parties and juries of their peers"). 
general. The problem with this is it undercuts the idea that constitutional norms should not apply. If the private plaintiffs are really delegees of state power, then the awesome power of the state is being used, albeit in a decentralized way. ${ }^{254}$

Second, Henry Hart argues that " $[\mathrm{w}]$ hat distinguishes a criminal from a civil sanction and all that distinguishes it ... is the judgment of community condemnation which accompanies and justifies its imposition." 255 A criminal sanction is "a formal and solemn pronouncement of the moral condemnation of the community. ${ }^{256}$ Employing this distinction, commentators have argued that punitive damages are civil and do not necessitate the safeguards of criminal procedure because they do not impose the stigma of moral condemnation that accompanies a criminal penalty. ${ }^{257}$ Regardless of whether this is a sensible line, however, it would seem that punitive damages actually fall on the criminal side of it. After all, the Supreme Court itself has declared that a "jury's ... imposition of punitive damages is an expression of its moral condemnation." ${ }^{258}$

An alternative ultimate line between the criminal and the civil law-one that offers a solution to the "constitutional puzzle" of punitive damages - is that, to be criminal, a sanction must be punishment for a public wrong. This is essentially a two-part test. The sanction must both be punishment and be intended to redress a wrong to society.

254. Zipursky, supra note 7, at 146 (citation omitted); see also BMW of N. Am., Inc. v. Gore, 517 U.S. $559,572 \mathrm{n} .17$ (1996) ("State power may be exercised as much by a jury's application of a state rule of law in a civil lawsuit as by a statute." (citing N.Y. Times Co. v. Sullivan, 376 U.S. 254, 265 (1964))); Browning-Ferris Indus. v. Kelco Disposal, Inc., 492 U.S. 257, 298 (1989) (O'Connor, J., concurring in part and dissenting in part) ("A governmental entity can abuse its power by allowing civil juries to impose ruinous punitive damages as a way of furthering the purposes of its criminal law.”); Mann, supra note 132, at 1814; Zipursky, supra note 7 , at 149 .

255. Henry M. Hart, Jr., The Aims of the Criminal Law, in CRIME, LAW AND SOCIETY 61, 64-65 (Abraham S. Goldstein \& Joseph Goldstein eds., 1971).

256. $I d$. at 65 .

257. See, e.g., Comment, supra note 121, at 410-11.

258. Cooper Indus., Inc. v. Leatherman Tool Group, Inc., 532 U.S. 424, 432 (2001); see also JOEL FEINBERG, The Expressive Function of Punishment, in DOING AND DESERVING: EsSAYS IN THE THEORY OF RESPONSIBILITY 95, 98-99, 104 (1970) (embracing Hart's theory but noting that punitive damages are a form of expressive condemnation); Donald Dripps, The Exclusivity of the Criminal Law: Toward a "Regulatory Model" of, or "Pathelogical Perspective" on, the CivilCriminal Distinction, 7 J. CONTEMP. LegAL IsSUES 199, 200 (1996) (noting that the moral condemnation model does not distinguish punitive damages because "[p]unitive damages are welded to moral condemnation"). 
Zipursky and Sebok doubt this line and its applicability to punitive damages. They do not see why the mere fact that punitive damages are punishment does not necessitate criminal procedural protections, regardless of whether they punish public or private wrongs. As Zipursky puts it, "punishment of private wrongs is still punishment, and it is therefore hard to explain why constitutional scrutiny appropriate to criminal punishment should apply to punishment of public wrongs but not to punishment of private wrongs." 259 Echoes Sebok, "it is hard to see why [Colby's] argument does not cut against his preferred theory of punitive damages as private punishment as much as the theory he attacks - punitive damages as public punishment." ${ }^{260}$ After all,

punishment of private wrongs is still punishment. Colby does not explain why, for instance, punishment of Jones by Private Citizen Smith for the wrong of stealing $\$ 10$, ooo would not be constrained by the same constitutional limits as punishment of Jones by the State of New York for larceny.... Why would due process not constrain Smith as a punisher in the same way that it constrains New York as a punisher? $?^{261}$

I will endeavor here to explain, first by reference to the case law. The Supreme Court has held that criminal procedural safeguards do not apply to all "sanctions that could, in common parlance, be described as punishment." 262 Rather, they apply only to "criminal punishments." 263 The Court generally defers to the legislative (or presumably common law) label of a sanction as criminal or civil, but "[e]ven in those cases where the legislature has indicated an intention to establish a civil penalty, [it has] inquired further whether the statutory scheme was so punitive either in purpose or effect,' as to 'transform what was clearly intended as a civil remedy into a criminal penalty." ${ }^{264}$ That inquiry is guided by the factors listed in Kennedy $v$. Mendoza-Martinez ${ }^{265}$ :

\footnotetext{
259. Zipursky, supra note 7 , at 142.

260. Sebok, supra note 78 , at 1005.

261. Id. at 1004 .

262. Hudson v. United States, 522 U.S. 93, 99 (1997) (citing United States ex rel. Marcus v. Hess, 317 U.S. 537,549 (1943)).

263. $I d$.

264. Id. (quoting United States v. Ward, 448 U.S. 242, 248 (1980); Rex Trailor Co. v. United States, 350 U.S. 148,154 (1956)).

265. 372 U.S. 144 (1963).
} 
(1) whether the sanction involves an affirmative disability or restraint;

(2) whether it has historically been regarded as a punishment;

(3) whether it comes into play only on a finding of scienter;

(4) whether its operation will promote the traditional aims of punishment-retribution and deterrence; (5) whether the behavior to which it applies is already a crime; (6) whether an alternative purpose to which it may rationally be connected is assignable for it; and (7) whether it appears excessive in relation to the alternative purpose assigned. ${ }^{266}$

These various factors will often point in different directions; the question is whether, considering them as a whole, they strongly contradict the legislative (or common law) civil label. ${ }^{267}$

Because it has relied on history to avoid the constitutional inquiry, the Supreme Court has never subjected punitive damages to this test. But Justice O'Connor once observed that it is "easy to conclude that punitive damages are penal under the Mendoza-Martinez factors." ${ }^{\prime 68}$ After all, they are and have historically been regarded as punishment; they only come into play on a finding of scienter; courts consistently speak of them as promoting the traditional aims of punishment (retribution and deterrence); they are quite often imposed for behavior that is also a crime; and the Supreme Court has conceded that, rather than serving some alternative purpose, they "serve the same purposes as criminal penalties." ${ }^{269}$

So then why do punitive damages not trigger criminal procedural protections? The answer is that Justice O'Connor was right: they do trigger those protections if they are understood as punishment for public wrongs, as they generally were at the time that Justice O'Connor was writing. But they do not trigger them if they are understood as punishment for private wrongs. The Mendoza-Martinez factors play out very differently if punitive damages are limited to punishment for private wrongs. When they are so limited, the last

266. Hudson, 522 U.S. at 99-10o (internal quotation marks omitted) (quoting Mendoza-Martinez, 372 U.S. at 168-69).

267. See id. at 101.

268. Browning-Ferris Indus. v. Kelco Disposal, Inc., 492 U.S. 257, 298 (1989) (O’Connor, J., concurring in part and dissenting in part).

269. State Farm Mut. Auto. Ins. Co. v. Campbell, 538 U.S. 408, 417 (2003). See generally Grass, supra note 106, at 245-313 (applying the Mendoza-Martinez factors to punitive damages); id. at 247 (" $[\mathrm{T}]$ he conclusion is inescapable that they are penal in nature, spirit, and jurisprudence, and thus mandate higher standards of procedural protection.”). 
two factors come into play: there is an alternative, noncriminal purpose for them, and they are carefully limited to fulfilling that purpose. And the other factors also apply very differently to punishment for private wrongs. The Mendoza-Martinez formulation is misleading, insofar as it focuses on punishment simpliciter without explicitly incorporating the original test for determining whether a sanction is "penal" in the way that would bring it across the civil/criminal line. In Huntington $v$. Attrill, the Court held that " $[\mathrm{t}]$ he test whether a law is penal, in the strict and primary sense, is whether the wrong sought to be redressed is a wrong to the public, or a wrong to the individual, according to the familiar classification of Blackstone."

Nearly a century ago, the Court relied on that principle in a case that heldin an unusual context-that punitive damages are not penal within the meaning of the Huntington test. O'Sullivan v. Felix ${ }^{271}$ involved a civil rights action brought by a man who was beaten by two other men in a successful effort to keep him from exercising his right to vote. The question for the Court was whether the action was time-barred, which depended on whether or not it was a penal action. If it was, then a longer federal limitations period applied. ${ }^{272}$ The Court explained that the federal civil rights laws in question provided for both "criminal proceedings and punishment for the public wrong, and actions in law or equity for the redress of any private injury." ${ }^{273}$ The Court found it "very clear that the public wrong is punished by the fines and punishment prescribed" and "the private injuries inflicted are to be redressed by civil suit." ${ }^{274}$ Citing Huntington, the Court concluded that the fact that the plaintiff demanded punitive damages stemming from the "signs of the degradation and humiliation placed upon him" ${ }^{275}$ was of no matter. Those damages were

270. 146 U.S. 657, 668 (1892); see also 73 AM. JUR. 2D Statutes $\$ 9$ (2001) (quoting the Huntington test as a lead-in to the Mendoza-Martinez factors); Hall, supra note 214 (recognizing that the distinction between civil and criminal law is based primarily on the fact that the former seeks to remedy individual harm and the latter seeks to remedy social harm); cf. Bloom v. Illinois, 391 U.S. 194, 201 (1968) (holding that when a contempt sanction operates as punishment for "a public wrong," it is a criminal sanction and necessitates criminal procedural protections). See generally supra note 134 (noting that the law treats the terms "crime" and "public wrong" as synonymous).

271. 233 U.S. 318 (1914).

272. See id. at 322.

273. Id. at 324 .

274. $I d$. at 325 .

275. Id. at 321 . 
intended to redress the private wrong to him, not the public wrong to society, and thus his action was not penal and was accordingly time-barred. ${ }^{276}$

276. To be fair, O'Sullivan may not be quite as clear a precedent as the text implies. In Huntington, the Court had explained,

In the municipal law of England and America, the words "penal" and "penalty" have been used in various senses. Strictly and primarily, they denote punishment, whether corporal or pecuniary, imposed and enforced by the State, for a crime or offense against its laws. But they are also commonly used as including any extraordinary liability to which the law subjects a wrongdoer in favor of the person wronged, not limited to the damages suffered.

Huntington v. Attrill, 146 U.S. 657, 666-67 (1892) (citations omitted) (citing United States v. Chouteau, 102 U.S. 603, 611 (1880)). When it declared that whether a law is "penal" depends on whether it seeks to redress a public or a private wrong, the Huntington Court explained that it was using "penal" in "the strict and primary sense," as opposed to the "commonly used" sense. Id. at 667-68. In citing Huntington, however, the O'Sullivan Court ran the two senses of "penal" together: "The term 'penalty' involves the idea of punishment for the infraction of the law, and is commonly used as including any extraordinary liability to which the law subjects a wrongdoer in favor of the person wronged, not limited to the damages suffered." 233 U.S. at 324 (citing Huntington, 146 U.S. at 666, 667; Chouteau, 102 U.S. at 611).

It is possible to read O'Sullivan as not addressing the "strict and primary" sense of "penalty" at all, but rather as holding merely that the action was not "penal" even in the "commonly used" sense, because it did not involve "extraordinary liability," but instead was "limited to the damages suffered." But the Court emphasized that the plaintiff sought "damages in the sum of $\$ 25,000$ 'for the wounding less than mayhem,' $\$ 25,000$ 'for the humiliation, degradation and public ridicule,' and \$10,00o 'as punitive and exemplary damages." Id. at 325. Insofar as they were sought as a supplement to the compensatory damages for the physical injury and the "humiliation, degradation and public ridicule," it is clear that the punitive damages were intended to go beyond compensation for the damages actually suffered. Immediately after defining the term "penalty" and citing Huntington, and immediately before listing the damages prayed by the plaintiff, the O'Sullivan Court gave the reason for its holding: "It is very clear that the public wrong is punished by the fines and punishment prescribed [by the criminal law], that the private injuries inflicted are to be redressed by civil suit, and the amount of recovery is determined by the extent of the injury received and the elements constituting it." Id. The punitive damages went beyond compensation for the injury suffered, but they were still designed to redress, and "determined by the extent of," that private injury - rather than the public wrong to society. See Colby, supra note 9, at 619, 639-40 (explaining that it was understood historically that, as punishment for private wrongs, "the proper amount of punitive damages depends on the severity of the injury to the plaintiff"). That is why they were not "penal." See also JamesDickinson Farm Mortgage Co. v. Harry, 273 U.S. 119, 125-26 (1927) ("Exemplary damages are recoverable at common law in many States. A statute providing for their recovery by and for the injured party is not a penal law [in the strict and primary sense].” (citing Huntington, 146 U.S. at 666-83)); Gruetter v. Cumberland Tel. \& Tel. Co., 181 F. 248, $250-54$ (C.C.W.D. Tenn. 1909) (stating that an action brought not to "remedy ... any public wrong, but merely for punitive damages for the breach of a common-law obligation or private wrong" is "essentially civil in its nature" and is not penal within the meaning of Huntington); 
The Huntington line also explains the Court's general failure to afford criminal procedural protections to so-called civil penalties - penalty provisions in civil statutes. The Court has insisted, often through the operation of legal fictions, that these penalties are not punishment for public wrongs. This insistence goes all the way back to Blackstone, who included actions for statutory penalties in his volume on private wrongs, rather than his volume on public wrongs, on the theory that they are simply damages for the breach of the implied contract that every member of society makes with the King. ${ }^{277}$ It is admittedly difficult to see why a breach of that contract is a private wrong, rather than a public one, but Blackstone's theory appears to be that the wrong was not visited upon the public order of the community, arousing fear and disorder in the public sphere, but rather was simply a breach of a private obligation to live up to the rules laid down by the government. The "victim" of that breach is the government, not society as a whole. The Supreme Court has employed similarly dubious fictions in upholding the constitutionality of various civil penalties, such as treble damages in antitrust and administrative penalties in environmental laws. ${ }^{278}$ The Court often finds, for instance, that the civil penalty is in reality simply a form of rough compensation to the government for the cost of enforcing the law, rather than an attempt to penalize the defendant for violating the law, and thus the penalty is really remedial, and is not punishment at all. ${ }^{279}$

The Court's use of dubious legal fictions in the civil penalties arena may not be particularly satisfying, and I make no effort to defend it. When it comes to punitive damages, however, there is either no need to employ similar legal fictions, or no opportunity to do so. As punishment for private wrongs, punitive damages really do serve a very different goal from the one that triggers criminal procedural safeguards. No fiction is necessary. But if punitive damages are punishment for public wrongs, then by definition they fall on the

S. Ry. Co. v. Decker, 62 S.E. 678, 682 (Ga. Ct. App. 1908) (explaining that the fact "that the damages are punitive does not render the statute which prescribes them penal" unless they are imposed for the purpose of "vindicating the public justice of the state").

277. See 3 BLACKSTONE, supra note 129 , at ${ }^{\star} 158-61$; Mann, supra note 132 , at 1820-21.

278. See Mann, supra note 132 , at $1802,1820-36$.

279. See Brunswick Corp. v. Pueblo Bowl-O-Mat, Inc., 429 U.S. 477, 485-86 (1977) (finding that treble damages in antitrust are "in essence a remedial" sanction); United States ex rel. Marcus v. Hess, 317 U.S. 537, 549 (1943) (holding that qui tam actions under the False Claims Act are civil because "[w]e cannot say that the remedy now before us requiring payment of a lump sum and double damages will do more than afford the government complete indemnity for the injuries done it"); Stockwell v. United States, 8o U.S. 531, 547 (1871) (finding that private civil actions seeking double or treble damages are compensatory, not penal); Mann, supra note 132, at 1823-30. 
criminal side of the line - they are the very definition of a criminal sanction. At that point, no fiction is possible; once we concede that they serve the same purpose as criminal sanctions, it is too late to come up with some sort of dubious legal fiction to avoid the Bill of Rights.

The Constitution thus mandates that, absent criminal procedural safeguards, punitive damages may be employed as punishment for private wrongs, but not as punishment for public wrongs. The Court therefore reached the proper result when it held in Williams that procedural due process demands that punitive damages may not be imposed to punish the defendant for harm caused to anyone other than the private, individual victim before the court. $^{280}$

The boundary between criminal and civil law that I have set out and the conclusion that punitive damages fall on one side of the line when punishing private wrongs, and the other side of the line when punishing public wrongs, ${ }^{281}$

280. Of course, this conclusion does not apply when punitive damages are accompanied by criminal procedural safeguards. This Article does not consider the feasibility of imposing those safeguards in civil lawsuits. C $f$. COLO. REV. StAT. $\$ 13-25-127$ (2005) (requiring proof beyond a reasonable doubt for punitive damages). I hasten to add that the mere fact that a sanction falls on the criminal side of the line does not necessarily mean that the full panoply of criminal procedural safeguards must attach. The law has long recognized that minor criminal penalties can be imposed in the absence of some constitutional safeguards. See, e.g., Callan v. Wilson, 127 U.S. 540, $55^{2}$ (1888) (holding that a jury trial is not required for petty criminal offenses); Mackin v. United States, 117 U.S. 348, 354 (1886) (holding that a grand jury indictment is required only for "infamous crimes"-those punishable by imprisonment). Thus, even though they are criminal in nature, awards of punitive damages (or other civil sanctions) that serve as punishment for public wrongs might not necessitate the full scope of criminal procedural safeguards, but would certainly trigger significantly greater procedural protections than are required when punishing private wrongs.

281. This does not mean that punitive damages as punishment for private wrongs raise no constitutional concerns. The Court has been forced by the language of the Bill of Rightsmany clauses of which apply only to "criminal" cases - to draw difficult lines and to hold on to a criminal/civil distinction that many legal theorists believe to be formalist and anachronistic. See, e.g., Holmes, supra note 196, at 44 (announcing that "the general principles of criminal and civil liability are the same"); David Friedman, Beyond the Tort/Crime Distinction, 76 B.U. L. REV. 103, 108-12 (1996) (arguing that the distinction between crime and tort is simply the product of historical accident). But the Constitution does not necessitate a degree of formalism that rises to the level of fundamental unfairness. Civil procedure may not be limited by the various criminal procedural protections of the Bill of Rights, but it is limited by the Due Process Clause. And due process necessitates heightened procedural protections for many noncriminal punitive sanctions. See Hudson v. United States, 522 U.S. 93, 102-03 (1997) (noting that even if a sanction is not criminal, its abusive potential is curbed by other constitutional provisions like the Due Process Clause). As such, the argument in this Article casts no doubt on the Supreme Court's recent decisions imposing procedural and substantive limits on punitive damages. It may, however, call into question Mark Geistfeld's suggestion that the constitutional limits imposed by the Court's 
are not only consistent with the admittedly murky doctrine, but also make good theoretical sense. ${ }^{282}$ As Zipursky explains, punishment for private wrongs-which he calls the plaintiff's private right to be punitive-is "importantly different from an exercise of the state power to punish" or from "the state authorizing an individual to carry out the state role of punishing." 283 It allows the plaintiff to vindicate her personal, private interests. It is not an end run around the Bill of Rights - a conscription of the plaintiff to do the state's dirty work without having to play by the rules imposed on the state by the Constitution. As Zipursky writes,

The state might be happy about the consequences of such an award, and might even maintain its regime in part because of these recognized consequences. But if the state is imposing punitive damages out of respect for a right of private redress, then the reasons for providing criminal procedural protections are not necessarily implicated. ${ }^{284}$

The Framers included criminal procedural protections in the Bill of Rights because they "fear[ed] the power of the state ... to coerce and repress. They fear[ed] that the state will use that power to eliminate its political enemies, as

pre-Williams punitive damages cases are likely applicable to other aspects of tort law, including pain and suffering damages. See Geistfeld, supra note 23, at 1101-12; see also BMW of N. Am., Inc. v. Gore, 517 U.S. 559, 607 (1996) (Scalia, J., dissenting). On my reading, those cases are best grounded in the fact that, unlike pain and suffering damages, punitive damages are punitive (albeit not criminal). See, e.g., Cooper Indus. Inc. v. Leatherman Tool Group, Inc., 532 U.S. 424, 432-36 (2001) (emphasizing the similarities between the Court's punitive damages cases and its criminal sanction cases).

282. Of course, if the Court were to take the line that I am advocating seriously, that decision would have implications extending beyond the realm of punitive damages: many ostensibly civil sanctions would be on tenuous constitutional footing. But those sanctions are already on tenuous constitutional footing. My line poses no greater threat to the current civil sanctioning regime than does the standard Mendoza-Martinez formulation, the full implications of which the Court has chosen to avoid through the use of legal fictions. If the Court wishes to continue to employ its legal fictions, it can explicitly endorse the proposed line without undermining other civil sanctions. Even if the Court were to purge its civil sanction jurisprudence of legal fictions, it is possible that many civil penalties might genuinely be justifiable on nonpunitive or private interest rationales. Those that could not would indeed have to be abandoned (or accompanied by heightened procedural safeguards), but doing so might not threaten the efficacy of the administrative regulatory state as much as one might fear. See generally Franklin E. Zimring, The Multiple Middlegrounds Between Civil and Criminal Law, 101 YALE L.J. 1901 (1992) (arguing that heightened procedural protections might not undermine the use or efficacy of civil administrative penalties).

283. Zipursky, supra note 7, at 153.

284. Id. at 156 . 
almost every state in human history has done." ${ }^{285}$ When punitive damages are used to vindicate the state's interests, they implicate those fears. When they are used to vindicate purely private interests, they do not. ${ }^{286}$

\section{Deterrence: The Elephant in the Room?}

The foregoing explains the retributive role of punitive damages. We are left, however, to grapple with the concept of deterrence. Courts, including the Supreme Court, have long maintained that "[p] unitive damages may properly be imposed to further a State's legitimate interests in punishing unlawful conduct and deterring its repetition." 287 The Williams Court began its analysis

285. Galanter \& Luban, supra note 175 , at 1457 ; see also Dripps, supra note 258 , at 204-05 (noting that the political origins of the criminal procedural safeguards in the Bill of Rights can be found in the Enlightenment desire to prevent the government from using its power to disable political opposition or to maliciously victimize members of politically unpopular groups); Fellmeth, supra note 198 , at 25 ("[T]he Bill of Rights was adopted primarily to protect citizens against the threats posed to their civil liberties by a state, motivated by ephemeral political forces, that may be less solicitous of those rights."); id. at 31-34 (arguing that the enhanced procedural protections of the Bill of Rights are needed only when the state, because its interest is directly at stake in the proceeding, has an incentive to abuse its power to punish the defendant).

286. Redish and Mathews argue that punitive damages are unconstitutional because they represent a "[d]irect vindication of the public interest [which] must be deemed a purely public power," and due process precludes the transfer of public power to private individuals. Redish \& Mathews, supra note 123, at 3-7, 13, 19. Whatever its merits may be, that argument is premised on the notion that punitive damages are punishment for public wrongs. Redish and Mathews focus on "the wholly punitive, and therefore purely public, nature of punitive damages," $i d$. at 4 , and argue that "when a private plaintiff furthers the public interest by collecting what amounts to a civil fine, that plaintiff is no longer pursuing his own private interest but rather is doing nothing more than effectively acting as an agent of the state," $i d$. at 16; see also id. at 33 (arguing that punitive damages "represent nothing more than a financial inducement to have these plaintiffs enforce the coercive power of the state"). As punishment for private wrongs, however, punitive damages are designed to vindicate private interests, not public ones. Of course, they still benefit the state in a number of ways. See generally Michael L. Rustad, How the Common Good Is Served by the Remedy of Punitive Damages, 64 TENN. L. REV. 793 (1997) (discussing the public benefits of punitive damages). But the mere "fact that punitive damages benefit the public interest does not mean that the point of the practice is to serve public ends." Sebok, supra note 78 , at 1035 . And so long as their purpose is to serve private, not public ends, they cannot be unconstitutional for the reasons offered by Redish and Mathews. Indeed, Redish and Mathews admit that compensatory damages in tort also serve ends desired by the state, but they conclude that the fact that compensatory damages at the same time serve valuable private ends is sufficient to sustain their constitutionality. See Redish \& Mathews, supra note 123, at 49-50. The same must be true of punitive damages as punishment for private wrongs.

287. BMW of N. Am., Inc. v. Gore, 517 U.S. 559, 568 (1996) (emphasis added). 
with a de rigueur recounting of that basic proposition - that punitive damages serve the goals of both punishment and deterrence. ${ }^{288}$ But then it never mentioned deterrence again; it focused only on punishment. ${ }^{289}$ What are we to make of that omission? One can easily imagine a situation in which the retributive punishment for a relatively minor private wrong to the plaintiff would be insufficient to deter the defendant and others from engaging in similar wrongdoing in the future. That is especially likely to be the case when the defendant profits from imposing relatively minor harms on many victims, only a small number of whom are likely to bring successful lawsuits. If any punitive awards are limited only to the amount necessary to avenge the moderate harm to the individual plaintiff, a rational defendant might well conclude that the expected profits still outweigh the expected damages and might continue to engage in the wrongdoing.

Some commentators have speculated that perhaps Williams essentially rejected the traditional deterrence rationale for punitive damages, leaving only the retributive one. ${ }^{290}$ At the opposite extreme, other commentators have suggested that perhaps Williams addressed only the retributive role of punitive damages, not the deterrent one, and thus still allows the jury to punish the defendant for harm to others, so long as it is done in the name of deterrence, rather than retribution. ${ }^{291}$ As I shall explain shortly, however, Williams need not be read to be either so radical ${ }^{292}$ or so inconsequential.

But first, consider a third possibility: that Williams was wrongly decidedand that my theory of punitive damages is erroneous - for failing to take into account the proper role of deterrence in punitive damages law. That is the

288. See 127 S. Ct. 1057, 1062 (2007).

289. See Michael P. Allen, Of Remedy, Juries, and State Regulation of Punitive Damages: The Significance of Philip Morris v. Williams, 63 N.Y.U. ANN. SuRV. AM. L. 343, 365 (2008).

290. See id.; Hubbard, supra note 56 , at 378,382 .

291. See Erwin Chemerinsky, More Questions About Punitive Damages, Trial, May 2007, at 72, 74 (2007) (implying this possibility).

292. That the Court has not abandoned the deterrence rationale for punitive damages is clear from its opinion in Exxon Shipping Co. v. Baker, 128 S. Ct. 2605 (2008), decided a year after Williams. Exxon is an atypical punitive damages case because the Court was exercising its maritime jurisdiction "in the manner of a common law court," $i d$. at 2619, and thus was "reviewing a jury award for conformity with maritime law, rather than the outer limit allowed by due process," id. at 2626. Still, even though the maritime common law excessiveness inquiry "precedes and ... obviate[s] any application of the constitutional standard," $i d$., the Court made clear that it was articulating its general "understanding of the place of punishment in modern civil law and reasonable standards of process in administering punitive law," id. at 2620; see also id. at $2634 \mathrm{n} .28$ (noting that the Court's analysis "may well" govern the constitutional inquiry). Deterrence concerns weighed very heavily in the Exxon Court's analysis. See id. at 2621-22, 2625, 2628, 2633 \& n.27. 
argument of Akhil Amar and Arthur McEvoy, who claim that "Colby argues that courts have always conceived of exemplary damages 'as punishment for the private legal wrong - the insult - done to the individual plaintiff," and then reject that argument as "flawed" because it ignores the long history of judicial recognition of the legitimate deterrent goal of punitive damages. ${ }^{293}$ Although Amar and McEvoy make an important point, their objection does not take them as far as they want to go. ${ }^{294}$

The Supreme Court's occasional references to punitive damages as serving the twin goals of "punishing unlawful conduct and deterring its repetition"295 are, as Judge Posner has explained, "cryptic, since deterrence is a purpose of punishment, rather than, as th[at] formulation implies, a parallel purpose, along with punishment itself, for imposing the specific form of punishment

293. Brief of Akhil Reed Amar and Arthur McEvoy as Amici Curiae in Support of Respondent at 9 n.10, Williams, 127 S. Ct. 1057 (No. 05-1256) [hereinafter Amar and McEvoy Brief] (quoting Colby, supra note 9).

294. To be clear, I do not mean to claim that courts always viewed punitive damages as punishment for private wrongs. My historical claim is that, when they understood punitive damages as punishment, courts traditionally viewed them as punishment for private wrongs, not public ones. I must be careful not to overstate even that claim. There is at least one case in which "punitive damages were not just levied to punish the harm done to a single plaintiff, but to the entire society." Rustad, supra note 239, at 475. In McBride v. McLaughlin, 5 Watts 375 ( $\mathrm{Pa} .1836$ ), the Supreme Court of Pennsylvania declared, "There are offences against morals to which the law has annexed no penalty as public wrongs, and which would pass without reprehension did not the providence of the courts permit the private remedy to become an instrument of public correction." Id. at 376. The McBride court opined that "no other principle" can explain damages above the level necessary for compensation than that their true purpose is to punish the wrong to society. $I d$. It specifically rejected the notion that the damages might be explained as vindicating the resentment of the victim, declaring that the "purposes of the law are more elevated than the gratification of revenge." Id. at 37677. But later in the nineteenth century, the Supreme Court of Pennsylvania changed course (in a case that, unlike McBride, raised double jeopardy concerns because the defendant's conduct was also punishable as a crime) and held that punitive damages punish only private wrongs to individuals. See Barr v. Moore, 87 Pa. 385, 393-94 (1878). Similarly, the high court of Mississippi once declared that it is the "duty" of the jury in cases in which "the law provides no other penalty" to impose punitive damages as "proper punishment for the disregard of public duty," in "the interests of society." New Orleans, Jackson \& Great N. R.R. Co. v. Hurst, 36 Miss. 66o, 666 (1859). But that court subsequently reversed course and declared that, although they serve "the public good, by deterring the offender and others from like offenses," the "imposition of [punitive] damages is not for the purpose of punishing an offense against the public justice, but rather to afford redress to the person injured.” Louisville \& N.R. Co. v. McCaskell, 53 So. 348, 349 (Miss. 1910); see also Colby, supra note 9, at $620 \&$ n.13o (noting that some early courts found that allowing punitive damages when the defendant's conduct was also punishable as a crime was inconsistent with double jeopardy principles).

295. BMW of N. Am., Inc. v. Gore, 517 U.S. 559, 568 (1996). 
that is punitive damages." ${ }^{296}$ Deterrence is not distinct from punishment; it is rather one of the two principal goals of punishment, the other being retribution. Thus, the Court is more accurate when it employs the formulation that punitive damages are imposed as punishment "for purposes of retribution and deterrence." ${ }^{297}$

It follows that the notion that punitive damages must be punishment for private wrongs, rather than public ones, incorporates the notion of deterrence. If deterrence is a purpose of punishment, and if the state cannot engage in punishment to serve the public good without criminal procedural safeguards, then it follows that the state cannot employ punitive damages to achieve the public benefits of deterrence without affording criminal procedural safeguards. Constitutionally, whether they seek retribution, deterrence, or both, punitive damages may punish only for private wrongs.

Amar and McEvoy are surely correct that early courts at times spoke of punitive damages as serving the societal goal of deterrence. ${ }^{298}$ To the extent that my prior work failed to make that sufficiently clear, it was admittedly incomplete. ${ }^{299}$ But those early courts tended to view punitive damages as vindicating public interests, rather than private ones. ${ }^{300}$ Amar and McEvoy might have also cited Bishop $v$. Stockton, in which the court declared that "exemplary damages may be given to indemnify the public for past injuries and damages, and to protect the community from future risks and wrongs." ${ }^{301}$

Once courts began to confront the constitutional obstacles to using punitive damages to vindicate society's interests, however, they backed away

296. Kemezy v. Peters, 79 F.3d 33, 34 (7th Cir. 1996). See generally United States v. Bajakajian, 524 U.S. 321, 329 (1998) ("Deterrence ... has traditionally been viewed as a goal of punishment....").

297. Pac. Mut. Life Ins. Co. v. Haslip, 499 U.S. 1, 19 (1991).

298. Sebok explains, however, that claiming that most of these cases stand for the proposition that "exemplary damages served a deterrence rationale" paints "too crude and hasty a picture of the meaning of exemplary damages." Sebok, supra note 99, at 202-03. In fact, to most of these early courts, "the point of such damages was not to prevent similar acts by allowing future wrongdoers to weigh the cost of their wrongdoing, but to use the past wrongdoing as an opportunity for the community to frame a norm." Id. at 203. This was more of an "expressive use of punishment" than a deterrent one. Id. Sebok explains that a genuine deterrence rationale was surprisingly rare in nineteenth-century cases. $I d$.

299. But cf. Colby, supra note 9, at 636, 668-70 (discussing the deterrent role of punitive damages).

30o. See, e.g., Wilkes v. Wood, (1763) 98 Eng. Rep. 489, 493 (C.P.) (rejecting the argument of the Solicitor General that "a private action [cannot be] represented as the cause of all the good people of England”).

301. 3 F. Cas. 453, 455 (Baldwin, Circuit Justice, C.C.W.D. Pa. 1843) (No. 1440). 
from that rationale, as my prior work makes clear. Amar and McEvoy concede that their historical analysis "do[es] not consider cases founded on retribution." ${ }^{02}$ That exclusion is difficult to justify when seeking to determine whether punitive damages can be used to punish the defendant for the harm done to third parties or to society. Deterrence and retribution are two sides of the punishment coin; the recognition in the retribution cases that the defendant cannot be punished for public wrongs had significant implications for the constitutional role of deterrence. Amar and McEvoy fail to cite or even to acknowledge the existence of the many nineteenth-century cases that treated punitive damages as punishment only for the private wrong to the individual. ${ }^{303}$ Nor do they address the crucial fact that the courts so held in the course of justifying the existence and constitutionality of punitive damages. ${ }^{304}$ One cannot properly assemble a puzzle if one leaves half of the pieces in the box. ${ }^{305}$

When courts began to recognize that punitive damages must vindicate private interests rather than public ones, they began to downplay the deterrent purpose of punitive damages. Consider, for instance, Wardrobe v. California Stage Co., a stagecoach accident case in which the California Supreme Court reversed a judgment for the plaintiff because the jury had been charged that it could give punitive damages "such as would be an example thereafter, which would tend to prevent such recklessness in the conduct of stages to the great peril of passengers." ${ }^{306}$ The court found this instruction "obnoxious" because it "devolves upon the jury the duty of punishing the defendants for what the Court seems to consider an offense to society, and by inflicting a penalty upon them, securing, by force of the example, future safety for the public." ${ }^{307}$ The court explained that the plaintiff could not act as "a public prosecutor, to vindicate the wrongs of the community; he was not the medium through

302. Amar and McEvoy Brief, supra note 293, at 3.

303. See Colby, supra note 9, at 614-29.

304. See supra Part III.

305. Indeed, any puzzle that could be pieced together using only the deterrence cases would not match the picture on the box. As I have explained, the fact that punitive damages were understood as punishment for private wrongs explains many features of historical and current punitive damages doctrine - such as the rule that punitive damages may be awarded only when the defendant is liable to the plaintiff for an underlying tort, and the rule that the amount of punitive damages must bear a reasonable relationship to the amount of compensatory damages - that appear nonsensical under a view of punitive damages as serving society's interest in deterrence. See Colby, supra note 9, at 637-43.

306. 7 Cal. 119, 120 (1857).

307. $I d$. 
which these rights were to be asserted or maintained." ${ }^{308} \mathrm{He}$ could recover punitive damages beyond mere compensation for his injuries, but he could not recover damages that "are professedly laid for the benefit of the public."309

Over the course of the nineteenth century, as they came to recognize that punitive damages exist to vindicate private interests, not public ones, the courts began to view the deterrent effect of punitive damages as merely a happy side effect of their primary role as private revenge. ${ }^{310}$ The standard judicial pronouncement was that "[e]xemplary, vindictive, or punitory damages are such as blend together the interests of society and of the aggrieved individual, and are not only a recompense to the suffering, but also a punishment to the offender and an example to the community." ${ }^{11}$ In other words, by punishing the private wrong to the victim, punitive damages achieve a deterrent effect that benefits all of society, but that public benefit is merely an incidental effect of the private punishment-and an unavoidable one at that. As the Iowa Supreme Court explained,

It is claimed by defendant's counsel that, in civil cases, damages ought to be limited to the extent that will operate alone upon the offender as a punishment, and a restraint of his future conduct; the example to others ought to be kept out of view. This is impossible, because, in all cases of punishment, the example will reach and affect the public. There cannot be a punishment without an example; the two are inseparable. If punishment be administered so there will be no example for the good or ill of the public, it ceases to be punishment. ${ }^{312}$

But punitive damages "are never allowed alone for the purpose of public good through the example given in their assessment"; rather, "[t]he effect upon the public is but an incident" of the private punishment. ${ }^{313}$ In other

308. Id.

309. Id.

310. Cf. MURPHY, supra note 195 , at 17 (arguing that when punishment is imposed as vengeance, deterrence is simply an accidental byproduct).

311. Fla. Cent. \& Peninsular R.R. v. Mooney, 24 So. 148, 150 (Fla. 1898).

312. Ward v. Ward, 41 Iowa 686, 688 (1875).

313. Id.; see also Watts v. S. Bound R.R., 38 S.E. 240, 242 (S.C. 1901) ("[P] unitive damages go to the plaintiff, not as a fine or penalty for a public wrong, but in vindication of a private right which has been willfully invaded; and, indeed, it may be said that such damages in a measure ... satisfy for the willfulness with which the private right was invaded, but, in addition thereto, operating as a deterring punishment to the wrongdoer, and as a warning to others."). 
words, public deterrence is an unavoidable (albeit perfectly desirable) result of punitive damages as punishment for private wrongs, but it is not and cannot be the driving force behind them. The jury cannot calibrate the damages by reference to the societal benefits of deterrence, and a punitive damages award that exceeds the appropriate level of retributive punishment for the private wrong cannot be justified on the ground that it is necessary to achieve the societal benefits of deterrence. To do so would be to convert it into a form of unconstitutional punishment for public wrongs.

There is, however, more to be said in favor of deterrence, even under a private revenge model of punitive damages. The fact that it is inappropriate to use punitive damages to serve society's interest in deterrence does not mean that deterrence is a wholly impermissible goal. Just as punitive damages are appropriate to satisfy the individual victim's private interest in retributionrevenge - so too are they appropriate to satisfy the individual victim's private interest in deterrence. The victim clearly has an interest in ensuring that the defendant does not victimize her again..$^{314}$ Thus, if a punitive damages award calculated by reference to her interest in individual revenge is not sufficient to deter the defendant from continuing to place her at risk of future harm, then it would be appropriate to increase the award even further. ${ }^{315}$ In that limited, but nonetheless significant, ${ }^{316}$ respect, I agree with Amar and McEvoy that deterrence is and has always been a legitimate use for punitive damages. ${ }^{317}$ That

314. See, e.g., Barry v. Edmunds, 116 U.S. 550, 562 (1886) (noting that a plaintiff may recover "exemplary damages calculated to vindicate his right and protect it against future similar invasio[n]s").

315. In doing so, however, the jury (and reviewing court) should focus only on the individual harm to the plaintiff. It should set the penalty at the amount that will ensure that the expected sanction for the wrong to the plaintiff (the total amount of punitive and compensatory liability multiplied by the likelihood that the private wrong would be successfully detected and prosecuted) exceeds the expected profit from the wrong to the plaintiff. This calculation is unaffected by whether the defendant actually harmed anyone else; it seeks only to ensure that it will not be profitable for the defendant to wrong the plaintiff again. See Geistfeld, supra note 125, at 301-02. To set the penalty with regard to actual harm to others, and the likelihood that the defendant will escape liability for it, is to impermissibly punish for the harm to nonparties. See Colby, supra note 9, at 668-71.

316. Although this notion of deterrence is limited to the individual's interest, not society's, it "can sometimes yield very high punitive damages." Colby, supra note 9, at 669 .

317. I disagree, however, that punitive damages may be used to completely "deter . . others ... from similar conduct in the future.” RESTATEMENT (SECOND) OF TORTS $\$$ 908(1) (1979). That might be a welcome side effect of punitive damages, but it cannot be a driving force behind them without violating procedural due process. See Galligan, supra note 10, at 126 (observing that my theory is inconsistent with this claimed purpose of punitive damages). 
interest was not at play in Williams, however, insofar as the individual victim was deceased and thus no longer at risk of harm. ${ }^{318}$

What is more, as Part V explains, if extracompensatory damages awards are divested of any pretense to punishment, Williams does not stand in the way of their use to achieve a different sort of deterrence.

\section{E. Evidence of Harm to Others To Determine Reprehensibility: The Exception that Swallowed the Rule?}

Thus far, I have sought to establish that punitive damages may not be used to punish the defendant (in the name of retribution or deterrence) for the harm caused to nonparties. Williams reached the correct result, albeit with inadequate reasoning. But what then to make of the Williams Court's declaration that, even though the jury may not punish the defendant for harming third parties, it may nonetheless consider that harm "in order to demonstrate reprehensibility" ? ${ }^{319}$ Commentators have tended to agree with the Williams dissenters that that distinction is so elusive as to be nonsensical. ${ }^{320}$ The problem is that, under the Supreme Court's decision in BMW of North America, Inc. $v$. Gore, which Williams purports to follow, the degree of reprehensibility of the defendant's conduct is the "most important" factor in determining the appropriate size of the punitive damages award. ${ }^{321}$ Williams says that juries should consider harm to others in determining the degree of reprehensibility of the defendant's conduct, and that juries should base the size of the punitive damages award on that degree of reprehensibility, but that juries cannot "use a punitive damages verdict to punish a defendant directly on account of harms it is alleged to have visited on nonparties." ${ }^{322}$ Is that not inherently contradictory? One commentator illustrates the absurdity with a proposed jury instruction:

318. See Geistfeld, supra note 125 , at 266-67. Geistfeld suggests that the interest in private revenge similarly is not at play in wrongful death actions. See id. at 272-73. But an individual has a strong dignitary interest in ensuring that her wrongful death will be avenged-every bit as much of an interest as she has in ensuring that her family or her estate will be compensated for the injury causing her death.

319. 127 S. Ct. 1057, 1064 (2007); see supra Section II.B.

320. See, e.g., Williams, 127 S. Ct. at 1067 (Stevens, J., dissenting); id. at 1068 (Ginsburg, J., dissenting); Allen, supra note 289 , at 359 ; Keith N. Hylton, Reflections on Remedies and Philip Morris v. Williams, 27 Rev. Litig. 9, 31 (2007); Kmiec, supra note 56.

321. 517 U.S. 559,575 (1996).

322. 127 S. Ct. at 1064 . 
Ladies and gentlemen of the jury, you are permitted to consider injury to nonparties to determine the level of reprehensibility of the defendant's conduct; however, you may not consider injury to nonparties when determining the amount of punitive damages to assess. The most important factor in determining the amount of punitive damages to assess is the level of reprehensibility of the defendant's conduct. ${ }^{323}$

On its face, that does indeed appear to be absurd. And the opinion only makes things worse when it declares that it is appropriate to consider harm to others in the name of reprehensibility because "[e]vidence of actual harm to nonparties can help to show that the conduct that harmed the plaintiff also posed a substantial risk of harm to the general public." ${ }^{24}$ This passage suggests that punitive damages awards can be used to redress the wrong to society by punishing the defendant for the harm that it caused-or threatened-to the general public, which is inconsistent with the notion that punitive damages must punish only private wrongs. And, as I have endeavored to demonstrate, the notion that punitive damages may punish only private wrongs is essential to the ultimate conclusion in Williams that it is unconstitutional to use punitive damages to punish the defendant for the harm to nonparties. So once again, the Court's reasoning seems contradictory and absurd.

Still, I believe that here, too, the Court essentially reached the correct result, albeit on the wrong rationale. Harm to others can be considered, in a limited way, in determining the reprehensibility of the wrong, and hence the amount of punitive damages - but not for the reason stated by the Court.

The reprehensibility inquiry does not examine the reprehensibility of the defendant's conduct in the abstract. Rather, once we recognize that punitive damages may serve as punishment only for the private wrong to the plaintiff, it follows that the only "reprehensibility" that matters is the reprehensibility of the private tort-the degree of reprehensibility of the defendant's wrongful disregard of the plaintiff's rights. Whether the defendant's conduct harmed or threatened harm to the general public is generally irrelevant to the reprehensibility of the private wrong; it is relevant only in determining the reprehensibility of the public wrong, which is not at issue in punitive damages cases. Still, if the fact that the defendant also harmed other individuals

323. Daniel Sulser Agle, Comment, Working the Unworkable Rule Established in Philip Morris: Acknowledging the Difference Between Actual and Potential Injury to Nonparties, 2007 BYU L. REV. 1317, 1355 .

324. Williams, 127 S. Ct. at 1064. 
illuminates the degree of reprehensibility of the wrong done to the plaintiff, then it might be relevant and admissible in a punitive damages case ${ }^{325}$ Michael Rustad offers a classic example in the case in which a jury "punished a television manufacturer for failing to take prompt remedial steps after it learned that its television sets caused a series of home fires." ${ }^{226}$ Rustad worries that the "admissibility of the other house fires caused by spontaneous combustion of the defective components would be questionable after Williams." ${ }^{227}$ But it should not be. The evidence of previous, known harm to others helps to demonstrate the reprehensibility of the decision to go ahead and sell the defective product to the plaintiff. ${ }^{328}$ It is therefore admissible, but only for this purpose..$^{329}$

Seen in this light, the Williams exception is both sensible-the reprehensibility of a tort often cannot be adequately ascertained in a vacuumand workable. If evidence of harm to others is admitted, the jury can and must be instructed that it can consider that evidence only to the extent that it aids in ascertaining the degree of reprehensibility of the individual wrong done to the plaintiff alone. The jury must be told that its job is to punish the defendant only for what it did to the plaintiff; it may not seek to punish the defendant for the harm that it caused to anyone else.

325. See Sebok, supra note 78, at 1032.

326. Michael L. Rustad, The Supreme Court and Me: Trapped in Time with Punitive Damages, 17 WIDENER L.J. 783, 823 (2008) (citation omitted).

327. Id. at $823-24$.

328. To give another example, if the defendant vandalized the plaintiff's property, evidence that the defendant does that sort of thing all the time could make his intentional disregard of the plaintiff's rights appear more reprehensible than would evidence that he had been trying to impress new friends by following through on a dare, and had never done anything like this before in his life. See Colby, supra note 9, at 667 ("[A] wrongful refusal to pay benefits due under an insurance policy would be more reprehensible-and thus deserving of greater punishment-if it were a part of a nationwide and company-wide practice of victimizing elderly or otherwise vulnerable insureds than it would be if it were simply the result of an isolated act of wrongdoing by one unsavory employee."). One imagines that, in many contexts, the fact that the defendant harmed only the plaintiff would make the private wrong more, rather than less, reprehensible. Plaintiff's counsel would be free to argue that the fact that the defendant treated every other customer with dignity and respect, but singled out the plaintiff alone for abuse, makes the disregard of the plaintiff's human dignity all the more reprehensible because it suggests that the wrongdoing was not simply an indiscriminately employed unsavory business practice - it was a personal slight.

329. And, of course, a trial judge should exercise caution in ensuring that the probative value of such evidence is not outweighed by its potential for prejudice. 


\section{FUTURE: THE END OF LAW AND ECONOMICS?}

What implications does Williams have for the future of punitive damages? On one reading, it essentially does nothing to change the practice of punitive damages on the ground. Because the jurors can still hear evidence of harm to others, any attempt to cabin what they do with that evidence through jury instructions will be futile, and they will go on imposing total harm punitive damages. ${ }^{330}$

I am skeptical of that assertion. A properly instructed jury should be able to see the difference between punishing the defendant for harming thousands or millions of victims, and considering harm to others only to provide the context necessary to determine the reprehensibility of the defendant's disregard of the individual plaintiff's rights. Specifically telling the jurors that they must punish the defendant only for what it did to the plaintiff, and that they are strictly forbidden from seeking to punish the defendant for what it did to anyone else, should lead to very different results in many cases. That is especially likely to be the case when accompanied by a rule that precludes plaintiff's counsel from making arguments about the appropriate punishment for injuring or killing thousands of people. ${ }^{331}$ In addition, reviewing courts will be more aggressive in striking down awards that would be reasonable as punishment for the full societal harm, but are excessive as punishment for the individual tort. Williams will, I believe, make a real difference. It will put an end to total harm punitive damages. ${ }^{332}$

But does it go too far? As a matter of retribution, I do not believe so. Williams allows the plaintiff to seek individualized revenge, which is the only retributive interest that can and should be at play in a civil lawsuit.

330. See Sebok, supra note 78 , at 1033 (suggesting that there will only be a "miniscule practical effect of adopting [Williams's] semantic distinction" between directly punishing harm to nonparties and considering that harm in determining reprehensibility); Insurance Companies Heart Williams Case, TortsProf Blog, Feb. 21, 2007, http://lawprofessors.typepad.com/ tortsprof/2007/o2/insurance_compa.html ("I would wager it will make exactly zero difference in the outcome."); $c f$. Alexandra B. Klass, Punitive Damages and Valuing Harm, 92 MinN. L. REV. 83, 150-53 (2007) (arguing that Williams will not preclude total harm punitive damages in environmental cases).

331. See, e.g., State Farm Mut. Auto. Ins. Co. v. Campbell, 538 U.S. 408, 420 (2003) (noting that the plaintiff s attorney told the jurors that they were "going to be evaluating and assessing, and hopefully requiring State Farm to stand accountable for what it's doing across the country, which is the purpose of punitive damages").

332. Cf. Goldberg, supra note 125 , at 7-8 (arguing that a private punishment view of punitive damages will tend to yield substantially lower awards than a public punishment and deterrence conception). 
Deterrence, however, may be a different story. The law and economics approach to punitive damages argues that punitive damages should serve as an engine of optimal deterrence; they should be used to ensure that the defendant internalizes the full social cost of its behavior. Compensatory damages are frequently insufficient to achieve that goal, insofar as defendants often escape liability for some of the harm that they cause. A rational actor might therefore engage in economically inefficient behavior-behavior that imposes more costs than benefits upon society-because it knows that it will receive the full benefits of the behavior, but will likely only be forced to bear a small portion of the costs. The object of punitive damages, on this view, is to ensure that potential wrongdoers understand that, even if they will escape compensatory liability for some of the harm that they cause, they will still be forced to internalize the full scope of the cost of their conduct through punitive damages awards. As such, they will have the proper incentive to engage in the behavior only to an economically efficient degree, and will expend appropriate resources to avoid causing harm (but only to the extent that the cost of the harm exceeds the cost of avoiding it). ${ }^{333}$

I have previously argued that, under this model, total harm punitive damages pose a serious risk of overdeterrence-of discouraging socially beneficial conduct. ${ }^{334}$ But perhaps eliminating them and focusing only on the private wrong to the individual victim will result in underdeterrence-that is, will fail to discourage socially harmful conduct. The risk of underdeterrence should not be overstated; as noted above, the deterrent potential of punishment for private wrongs is actually quite substantial. ${ }^{335}$ Still, it is quite possible that punishing only the private wrong will have the effect of underdeterring in many circumstances, such as in wrongful death actions, when the victim no longer has a private interest in deterrence that can be considered in assessing punitive damages.

One imagines that some state legislatures (or state courts) might seek to do something about that. ${ }^{336}$ Taking the advice of law and economics scholars, they might want to create an extracompensatory sanction designed to achieve optimal deterrence by ensuring that the defendant fully internalizes the costs of its behavior.

333. See, e.g., Ciraolo v. City of New York, 216 F.3d 236, 243-44 (2d Cir. 200o) (Calabresi, J., concurring); Thomas C. Galligan, Jr., Augmented Awards: The Efficient Evolution of Punitive Damages, 51 LA. L. REV. 3, 40-58 (1990); Polinsky \& Shavell, supra note 125, at 877-96; Sharkey, supra note 9, at 365-70.

334. See Colby, supra note 9, at 612 n.98.

335. See supra Section IV.D.

336. See Sharkey, supra note 9, at 414-28. 
A number of commentators have opined that Williams forecloses the states from doing so. ${ }^{337}$ That view is certainly understandable if one accepts the Williams reasoning on its face. Ensuring that the defendant internalizes all of the social costs of its activity turns the focus to the harms allegedly visited upon nonparties, which Williams appears to preclude. ${ }^{338}$ But if one accepts the thesis of this Article - that ultimately Williams must rest on the principle that it is unconstitutional to punish for public wrongs without criminal procedural safeguards - then the issue looks very different.

The cost-internalization sanction favored by the law and economics school seeks to serve the public good, rather than to vindicate a private tort right of the plaintiff. Indeed, it seeks to fix the sanction by reference to "the total harm caused" by the defendant ${ }^{339}$ - "the harms inflicted by the defendant upon parties not before the court," including both "specific harms' to identifiable individuals, and more 'diffuse harms' that affect society in general." 340 That sanction is certainly "quite similar" ${ }^{441}$ to the total harm punitive damages that I have argued are unconstitutional, and that Williams has struck down. But it is not the same thing, and the distinction makes all the difference. ${ }^{342}$

337. See Allen, supra note 289 , at 368 (finding it "unlikely" that the optimal deterrence rationale for punitive damages "survived Philip Morris"); Hubbard, supra note 56, at 384 (arguing that, in the line of cases culminating in Williams, the Court has used "the Due Process Clause to deny a state the right to apply these widely accepted theories in adopting an approach to deterrence"); Hylton, supra note 320, at 17-21; Rustad, supra note 8, at 499-501; Sheila B. Scheuerman, Two Worlds Collide: How the Supreme Court's Recent Punitive Damages Decisions Affect Class Actions, 6o BAYLOR L. REV. (forthcoming 2008) (manuscript at 52-53, on file with author); Paul B. Rietema, Recent Development, Reconceptualizing Split-Recovery Statutes: Philip Morris USA v. Williams, 127 S. Ct 1057 (2007), 31 HARV. J.L. \& PUb. POL'Y 1159, 1166 (2008) ("By prohibiting consideration of third-party harm, the Court has, under the guise of the Due Process Clause, mandated an individual-oriented punitive framework.... [S] tates may no longer use punitive damages to encourage socially optimal deterrence as traditionally conceived - where the focus is on creating full internalization of harm in a world of partial enforcement ....”).

338. Similarly, if the result in Williams is grounded, as other defenders of the decision would have it, in the civil recourse principle - that tort remedies may not be employed for the primary purpose of serving public regulatory goals, see supra note 125 and accompanying text-then the law and economics model fails for shifting the focus from the victim's interests to society's. See also supra note 286 and accompanying text (discussing the theory of Martin Redish and Andrew Mathews).

339. Ciraolo v. City of New York, 216 F.3d 236, 244 (2d Cir. 200o) (Calabresi, J., concurring).

340. Sharkey, supra note 9, at 392.

341. Anthony J. Sebok, Deterrence or Disgorgement? Reading Ciraolo after Campbell, 64 MD. L. REV. 541, 566 n.126 (2005).

342. For an initial discussion of the difference between cost internalization and total harm punitive damages, see Colby, supra note 9, at 612 n.98. 
This Article has sought to explain that, in order to be criminal in nature and thus to necessitate criminal procedural protections, a sanction must not only seek to redress the harm to society; it must seek to punish the defendant for the harm to society. It must be a form of punishment. As such, the fact that cost internalization takes into account the harm to others to serve the public interest does not make it criminal, unless it is also a form of punishment. Of course, at first glance, it might appear that it is indeed punishment. It is imposed in the name of deterrence, which, as noted above, is a goal of punishment. ${ }^{343}$ But the matter is not quite so simple. Although it is often averred that "when it comes to deterrence, civil and criminal remedies are essentially indistinguishable and interchangeable,"344 in fact, properly understood, the deterrence sought by civil remedies is distinct from the deterrence sought by criminal ones. ${ }^{345}$

How to articulate that distinction is a matter of some dispute. Mark Geistfeld opines that the distinction has to do with whom the remedy seeks to deter. A remedy that seeks "specific deterrence"-deterrence of the defendant alone-is civil, but a remedy that seeks "general deterrence"-deterrence of others besides the defendant-is criminal. ${ }^{346}$ Thomas Galligan draws the line in the same terms, but reaches the very opposite conclusion: a remedy that seeks specific deterrence is criminal, but a remedy that seeks general deterrence is noncriminal. ${ }^{347}$ John Coffee, by contrast, draws the civil/criminal line not on the basis of the identity of the person or persons that the remedy seeks to deter-the defendant alone or all other potential wrongdoers - but rather on the basis of the level of deterrence sought-whether the sanction seeks to deter the activity completely, or merely to ensure that the defendant engages in it only to a socially optimal degree. ${ }^{348}$ Along those lines, Keith Hylton explains that the "traditional notion of deterrence in the criminal punishment literature is one of 'complete deterrence,' of stopping offenders from committing

343. See supra Section IV.D.

344. Mary M. Cheh, Constitutional Limits on Using Civil Remedies To Achieve Criminal Law Objectives: Understanding and Transcending the Criminal-Civil Law Distinction, 42 HASTINGS L.J. 1325, 1355 (1991).

345. See Keith N. Hylton, Punitive Damages and the Economic Theory of Penalties, 87 GeO. L.J. 421, 421 (1998).

346. Geistfeld, supra note 23 , at 1096-99.

347. Galligan, supra note 10 , at 148 .

348. See John C. Coffee, Jr., Paradigms Lost: The Blurring of the Criminal and Civil Law ModelsAnd What Can Be Done About It, 101 YALE L.J. 1875, 1884 (1992). 
offensive acts." 349 By contrast, the "alternative, more recent notion of deterrence, largely observed in the torts literature, is that of 'appropriate or optimal deterrence,' which implies deterring offensive conduct only up to the point at which society begins to lose more from deterrence efforts than from the offenses it deters." 350

It is my position that, in fact, the line between civil and criminal deterrence turns on both of these factors. Again, because criminal penalties punish public wrongs, criminal deterrence must both be punishment and be intended for the good of society. It is a two-prong inquiry, and each of these factors addresses a different prong.

The first question is whether the deterrence is punitive. This inquiry turns on the degree of deterrence sought. Optimal deterrence does not necessarily seek to prevent conduct. It merely seeks to ensure that an actor who engages in the conduct employs the proper safety precautions and engages in it only to an optimal degree. Thus, when society's gain from the actor's conduct is greater than society's loss, an optimal deterrence regime allows the actor to keep doing it, so long as he pays for any harm that he causes along the way. Despite the fact that it causes harm, we want him to keep doing it because society derives a net benefit from his activity. ${ }^{351}$

As Kenneth Simons explains, in an optimal deterrence regime, the actor "is entitled to harm the victim so long as he pays for the harm (with the expectation that this entitlement will induce him to take optimal care)," whereas in a complete deterrence regime, the actor "is not entitled to harm the victim even if [he] is willing to pay for that harm." ${ }^{352}$

Optimal deterrence is not a punitive concept. ${ }^{353}$ Society does not "punish" someone for doing something that it affirmatively wants him to do. ${ }^{354}$ Complete deterrence, however, is punitive. The goal of punishment, when it is imposed in the name of deterrence, is to prevent wrongful conduct-to deter it

349. Hylton, supra note 345 , at 421 . This concept is often referred to as "classical deterrence." Id. at 421 n.1.

350. Id. at 421; see also Galligan, supra note 333 , at 8-10 (noting the difference between these two forms of deterrence).

351. See Polinsky \& Shavell, supra note 125 , at 882.

352. Kenneth W. Simons, Deontology, Negligence, Tort, and Crime, 76 B.U. L. ReV. 273, 273 (1996); see also Coffee, supra note 348 , at 1876 \& n.6 (explaining that this pricing/prohibition distinction can be expressed as the difference between optimal and total deterrence).

353. See Galligan, supra note 10, at 129.

354. See supra note 185 (noting that the concept of punishment implies the commission of an offense). 
completely. ${ }^{355}$ Punishment seeks to ensure that persons will not engage in conduct, regardless of whether it produces more benefits to the wrongdoer (or to society) than harm to others. Punishment forces the wrongdoer to disgorge the full amount of his gain to prevent him from having a perverse incentive to keep doing something that the law considers to be inimical to the public interest, whether it is efficient or not. ${ }^{356}$

A sanction that seeks complete deterrence is thus a punitive sanction, but that does not mean that it is a criminal sanction. That depends on the second question: whether it seeks primarily to serve the public interest of society or the private interest of the plaintiff. That is the inquiry that turns on the identity of the person or persons sought to be deterred. General deterrence (of the defendant and everyone else) is designed to serve the public interest in regulating behavior. Specific deterrence (of the defendant alone) is designed to serve the private interest in vindicating the plaintiff's tort right.

355. See Hylton, supra note 345, at 423 ("The goal of punishment should be complete deterrence.”).

356. See Hylton, supra note 320 , at 15 . The distinction between optimal and complete deterrence is not without its conceptual problems. At one level, complete deterrence could be thought of as simply an application of optimal deterrence. After all, as Judge Easterbrook has noted, "[t]he optimal amount of fraud is zero." Ackerman v. Schwartz, 947 F.2d 841, 847 (7th Cir. 1991). But of course, actually achieving a fraud level of zero might only be possible by imposing penalties so high that actors will over-invest in prevention, such that the costs invested in avoiding the fraud exceed the costs that the fraud would have imposed. Indeed, if the penalties for fraud were high enough, actors might avoid engaging altogether in any socially beneficial activities that carry with them even a slight risk of fraud liability. In that regard, perhaps no legal sanction - not even a punitive one-should be truly interested in complete, as opposed to optimal, deterrence. Indeed, in his seminal economic analysis of the criminal law, Gary Becker proposed an optimal deterrence-rather than complete deterrence - model of criminal punishment. See Gary S. Becker, Crime and Punishment: An Economic Approach, 76 J. POL. ECON. 169, 198-99 (1968). That has not, however, been the traditional understanding of the criminal law. See Keith N. Hylton, The Theory of Penalties and the Economics of Criminal Law, 1 REV. L. \& ECON. 175, 176 (2005) (noting that "criminal law adopts a policy of prohibition; it does not seek to constrain murder, theft, or rape to 'optimal' levels"); id. at 176 n.4 (noting that Cesare Beccaria and Jeremy Bentham endorsed the notion that the criminal law should completely deter). One way to conceive of the distinction between optimal and complete deterrence is that complete deterrence is sought for practices that society would, in an ideal world, like to eliminate altogether (even if the realities of enforcement costs and marginal deterrence make that goal unachievable and perhaps even undesirable in practice), whereas optimal deterrence is sought for practices that society has no particular desire to eliminate altogether, so long as they remain economically efficient. Cf. Gerard E. Lynch, The Role of Criminal Law in Policing Corporate Misconduct, LAW \& CONTEMP. Probs., Summer 1997, at 23, 41-43 (arguing that the pricing/prohibition distinction ultimately turns on society's moral judgment of the behavior). 
Of course, the plaintiff also has an interest in general deterrence in the sense that she does not want to get hurt by someone other than the defendant either. But any interest that she has in avoiding being harmed by others is one that she shares equally with everyone else in society. The interest that she has in avoiding repeated harm at the hands of the defendant, by contrast, is unique to the relationship between the two of them; it is a part of the private tort right that she seeks to vindicate in the civil action that she has filed against him.

By the same token, society also has an interest in specific deterrence in the sense that it wants to ensure that the defendant is adequately deterred. Yet society's interest in deterrence is necessarily broader. Why would the public have an interest in ensuring that one person does not act (or that he engages in an activity only to an optimal degree) but not care whether and to what extent anyone else engages in the same harmful activity? If a remedy is seeking specific deterrence, aimed at the defendant only, then it must be targeted primarily at the individual victim's interests, not society's.

Thus, a sanction imposed in the name of deterrence is criminal in nature and necessitates criminal procedural safeguards only if it seeks complete and general deterrence. That is precisely the end sought by punitive damages as punishment for public wrongs: ensuring that neither the defendant nor anyone else $^{357}$ will ever engage in this activity again, ${ }^{358}$ even if the conduct is economically efficient. The Supreme Court has explained that the prevailing modern understanding of punitive damages is premised on the notion that "“[c]itizens and legislators may rightly insist that they are willing to tolerate some loss in economic efficiency in order to deter what they consider morally offensive conduct, albeit cost-beneficial morally offensive conduct."'359

But a sanction that seeks complete and specific deterrence-like punitive damages employed as punishment for private wrongs - is not criminal. ${ }^{360}$ And a sanction that seeks optimal deterrence is not punishment, and thus is not criminal regardless of whether it seeks to regulate the behavior of the

357. See, e.g., Pac. Mut. Life Ins. Co. v. Haslip, 499 U.S. 1, 19 (1991) (declaring that one of the purposes of punitive damages is "protecting the public by [deterring] the defendant and others from doing such wrong in the future" (internal quotation marks omitted)).

358. See John C. Coffee, Jr., Does "Unlawful" Mean "Criminal"?: Reflections on the Disappearing Tort/Crime Distinction in American Law, 71 B.U. L. Rev. 193, 194 n.4 (1991) (noting that "punitive damages ... clearly are intended to prohibit, rather than price"); Galligan, supra note 333, at 9 n.7 (noting that, when courts speak of the deterrent function of punitive damages, they are referring to complete deterrence through punishment).

359. Cooper Indus., Inc. v. Leatherman Tool Group, Inc., 532 U.S. 424, 439-40 (2001) (quoting Galanter \& Luban, supra note 175 , at 1450 ).

36o. See supra Sections IV.C-D. 
defendant only (specific deterrence) ${ }^{361}$ or the behavior of all other actors in society (general deterrence).

The law and economics vision of punitive damages as an engine of cost internalization falls into the last category. It seeks to regulate broadly - to serve societal interests through general deterrence ${ }^{362}-$ but it seeks only optimal deterrence, not complete deterrence. ${ }^{363}$ The law and economics movement has long understood that much behavior that causes great harm also brings even greater benefits, and thus must not be prohibited. ${ }^{364}$ The object of cost internalization is simply to ensure that individuals or parties engage in such behavior to an optimal degree, with optimal efforts to reduce the costs that it imposes. Law and economics scholars have accordingly insisted that their model of punitive damages is not really "punitive" at all, ${ }^{365}$ and that their sanction should be imposed regardless of the mental culpability of the

361. Dan Dobbs argues that punitive damages should be adapted to play the role of ensuring specific, optimal deterrence, and he correctly notes (without elaboration) that adapting them to this end would neutralize the argument that they should not be awarded without criminal procedural safeguards. See Dan B. Dobbs, Ending Punishment in "Punitive" Damages: Deterrence-Measured Remedies, 40 ALA. L. REV. 831, 854-56, 858-59 (1989).

362. See Polinsky \& Shavell, supra note 125 , at 877 ("By deterrence, we mean what is often called general deterrence, namely, the effect that the prospect of having to pay damages will have on the behavior of similarly situated parties in the future (not just on the behavior of the defendant at hand).").

363. See Ciraolo v. City of New York, 216 F.3d 236, 243 (2d Cir. 200o) (Calabresi, J., concurring); Polinsky \& Shavell, supra note 125, at 954. Keith Hylton disagrees with other law and economics scholars when he argues that punitive damages generally should seek complete deterrence, not simply cost internalization. See Hylton, supra note 320 , at 15 . As such, Williams - as I seek to reconstruct it-bars the states from adopting his recommendation. Most of the other law and economics scholars who have analyzed punitive damages have concluded that sometimes, when the defendant's behavior is sufficiently morally reprehensible, it might be appropriate to seek complete deterrence rather than optimal deterrence. See, e.g., Polinsky \& Shavell, supra note 125, at 909-10, 920 (arguing that, when an individual defendant's benefit from the conduct was purely malicious, in the sense that it was derived from the fact of causing the harm, then the sanction should aim for complete deterrence). As Judge Calabresi acknowledges, however, that "function of punitive damages renders them analogous to criminal penalties that seek not to achieve a socially optimal level of activity, but to discourage or even eliminate a particular activity altogether," at which point "it would be appropriate to reconsider the procedural protections that should attach before such an award can be made." Ciraolo, 216 F.3d at 246 n.8.

364. See Guido Calabresi, Ideals, Beliefs, Attitudes, and the LaW 1-3 (1985) (discussing automobiles).

365. See Ciraolo, 216 F.3d at 245 (Calabresi, J., concurring); Galligan, supra note 333, at 13; Polinsky \& Shavell, supra note 125, at 890-91; Sharkey, supra note 9, at 389-90. 
defendant. ${ }^{366}$ If one were to run the cost internalization sanction through the Kennedy v. Mendoza-Martinez factors, ${ }^{367}$ it would clearly come out as noncriminal: it is not labeled as punishment; it is not regarded as punishment by those who advocate it; it does not come into play only on a finding of scienter; it does not promote the traditional goals of punishment-retribution and complete deterrence; it applies to conduct that is not necessarily criminal; and it is carefully targeted to serve an alternative, nonpunitive purpose. ${ }^{368}$ It is thus not a criminal sanction, and the Williams decision should not be read to preclude it. ${ }^{369}$ Justice O'Connor once wrote, in discussing punitive damages, that " [j] $\mathrm{j}$ ust as the Fourteenth Amendment does not enact Herbert Spencer's Social Statics,' it does not require us to adopt the views of the Law and Economics school either." 370 But at the same time, it does not prohibit us from

366. See Ciraolo, 216 F.3d at 246 (Calabresi, J., concurring); Galligan, supra note 333, at 62-63; Polinsky \& Shavell, supra note 125 , at 874 .

367. See supra text accompanying note 266.

368. Cf. United States v. Ward, 448 U.S. 242, 254 (1980) (noting that a sanction can be nonpenal - noncriminal - if it has a "correlation to any damages sustained by society").

369. Cf. Cooper Indus., Inc. v. Leatherman Tool Group, Inc., 532 U.S. 424, 440 n.13 (2001) (noting that if a state were to adopt a damages remedy that seeks optimal economic efficiency, a different constitutional analysis would apply); Calabresi, supra note 23, at 339 (noting that, when punitive damages seek only cost internalization, "as no semi criminal law objectives are at play, there is no reason to impose procedural safeguards"); Coffee, supra note 348 , at 1883 (arguing that a penalty that goes beyond cost internalization is "'punishment' (in the constitutional sense)," whereas a "penalty equal to the social cost of the behavior can be described as nonpunitive," and thus "the full constitutional safeguards applicable to criminal prosecutions need not apply"); Fellmeth, supra note 198, at 54-55, 59 (arguing that a "deterrent" sanction that necessitates criminal procedural protections is one that leads to complete deterrence, rather than one that allows the defendant to pay for the harm that it causes while continuing to engage in harmful behavior); Galligan, supra note 10, at 149-150 (noting that, even if the Supreme Court in Campbell adopted the theory that punitive damages may not punish public wrongs, it did not necessarily signal the end of punitive damages as an engine of optimal deterrence, since they would be nonpunitive); Sharkey, supra note 9, at 401 ("By reconceptualizing these underdeterrence damages as societal compensation, as opposed to quasi-fines or penalties, the societal damages approach would seem to survive the retributive-punishment-focused due process constraints of State Farm ....”). For this reason, I disagree with Zipursky's conclusion that cost internalization "really fall[s] on the criminal side of the divide," Zipursky, supra note 7, at 141, and with Sebok's conclusion that cost internalization is a form of "punishment" or "penalty" that is ultimately subject to the same due process constraints that apply to traditional punitive damages, Sebok, supra note 341, at 547-49, 569.

370. TXO Prod. Corp. v. Alliance Res. Corp., 509 U.S. 443, 491-92 (1993) (O'Connor, J., dissenting) (citation omitted) (quoting Lochner v. New York, 198 U.S. 45, 75 (1905) (Holmes, J., dissenting)). 
adopting the views of the law and economics school. ${ }^{371}$ Williams does not stand in the way of implementing an extracompensatory remedy that seeks optimal deterrence. ${ }^{372}$

Even so, Judge Calabresi, a champion of cost internalization, is unsatisfied. In a thought-provoking recent essay, he argues that punitive damages can serve, and often have served, a variety of "very different functions," and he explains that "each function, if it were the sole object of such extracompensatory damages, would have rules and limits that make no sense if one examines punitive damages through the prism of a different function." ${ }^{373} \mathrm{It}$ may be perfectly sensible for an academic to adopt a single, unified model of punitive damages, he says, but for a court to do so is "foolishness" 374 :

What may well be right from a unidimensional and reductionist view of a torts problem, what is the basis of a very helpful and deep analysis by a scholar like Colby, what may even be correctly seen - as Colby asserts-as the historical origin of punitive damages in America,

371. At least not for the reasons that underlie Williams. I take no position here on whether costinternalization damages raise other constitutional concerns. See, e.g., Zipursky, supra note 7 , at 141-42, 148 (suggesting that even nonpunitive, noncriminal regulation through private tort actions can raise constitutional problems). Nor do I opine on whether Catherine Sharkey's intriguing proposal to create "societal compensatory damages"-damages that seek to ensure both cost internalization and the compensation of other victims (and society more generally), see Sharkey, supra note 9; cf. Ciraolo, 216 F.3d at 247 (Calabresi, J., concurring) (making a similar proposal)-might be unconstitutional for other reasons, despite their noncriminal nature. See, e.g., Michael B. Kelly, Do Punitive Damages Compensate Society?, 41 SAN DIEGO L. REV. 1429, 1434 (2004) (outlining several potential due process objections to awarding societal compensatory damages based on injuries to absent parties); cf. Colby, supra note 9, at 592-602 (noting the potential for unfairness that such a remedy would need to avoid).

372. One might speculate that, as a practical matter, it would be impossible for reviewing courts to ascertain whether extracompensatory damages were awarded in the name of optimal deterrence, rather than complete deterrence (and/or public retribution). A state could, however, easily implement the law and economics sanction in a way that would leave no doubt on the question. A state seeking to do so could (and should) drop the "punitive" label altogether, abandon the scienter requirement, preclude jury argument based on notions of retribution or complete deterrence, and instruct the jury pursuant to a law-and-economicsinspired multiplier formula. Indeed, the jury instructions could explicitly inform the jurors that their task is not to punish, or to stamp out the activity, but simply to ensure that the defendant absorbs all of (but nothing more than) the cost of the harm that it causes.

373. Calabresi, supra note 23 , at 336.

374. Id. at 346; see also David F. Partlett, Punitive Damages: Legal Hot Zones, 56 LA. L. ReV. 781 , 792 (1996) (opining, before Campbell and Williams, that "courts have shown a good deal of wisdom to resist academic categorizations urging singular normative bases for punitive damages"). 
becomes dangerously wrong when applied across the board as a matter of constitutional necessity by a torts-ignorant Court to a multidimensional and complex set of problems! $!^{375}$

While the rule that punitive damages may not redress harm to nonparties makes sense when punitive damages are understood as a form of punishment, it becomes "dangerous, and almost silly, if one accepts the possibility that the common law of any given state may have had some or all of the other rationales 'in mind' when it developed its own rules and limits on punitive damages." ${ }^{\prime 36}$

Judge Calabresi's point is well taken, but it can, I think, be answered. As the foregoing discussion of the cost-internalization sanction makes clear, the fact that the Court has placed appropriate limits on genuinely punitive damages does not mean that the states may not choose to adopt (or continue in effect) nominally "punitive" damages that are in fact designed to serve other, nonpunitive functions. In other words, contrary to the objections of critics, Williams does not constitutionalize the view of punitive damages as punishment for private wrongs. ${ }^{377}$ Rather, it simply takes off the table one of the many possible uses for punitive damages - punishment for public wrongs. The states are free to adopt (or continue in effect) other forms of extracompensatory damages that serve one or more alternative goals; they simply need to make clear that these damages are not a form of impermissible punishment and to make sure that they are never used as one.

Judge Calabresi recognizes this, but he believes that there are substantial costs to forcing the states to do so: " $[\mathrm{I}] \mathrm{n}$ the end a society may . . . be better served by the retention of multipurposed, somewhat inconsistent concepts." ${ }^{78}$ Punitive damages have traditionally served many purposes at once, have unconsciously promoted additional values as well, and have even served goals

375. Calabresi, supra note 23, at 346. Judge Calabresi was writing before Williams but was of the opinion that the Campbell Court had already adopted my position. See id.

376. Id.

377. But see Allen, supra note 289 , at $364-65$ ("[B]y framing the issue as one of federal constitutional law, the Court has made it practically impossible for any entity other than itself - state or federal - to change this stunted conception of punitive damages."); Rustad, supra note 239, at 464 (" $[\mathrm{T}]$ he United States Supreme Court is forcing the states into a common mold based upon an individualistic retributory jurisprudence bypassing the multiple functions of punitive damages that have evolved over two centuries of AngloAmerican jurisprudence.").

378. Calabresi, supra note 23 , at 347 . 
that we secretly desire but do not want to admit to openly. ${ }^{379}$ To force the states to spell out the exact purpose and function of punitive damages is to force them to give up these benefits. Judge Calabresi believes that it is wrongheaded and unduly disrespectful of state sovereignty for the Supreme Court to require them to do so. ${ }^{380}$

In the abstract, I am agnostic on the relative advantages of, on the one hand, mandating the clarification of muddled doctrines and, on the other hand, allowing the blurring of doctrinal rationales in order to serve varied and perhaps even conflicting interests - although I am inclined to defer to Judge Calabresi's wisdom and experience here. ${ }^{381}$ And I wholeheartedly agree with Judge Calabresi that this choice should ordinarily be one for the states to make; the Supreme Court should generally butt out of the common law. But in this particular instance, I believe that the Constitution forces the Court's hand. By way of analogy, if a state imposed a poll tax that had come to serve the purposes of both raising money and precluding the poor from voting, that tax would be unconstitutional. ${ }^{382}$ The fact that, in part, it served a legitimate interest-revenue raising-would not save it. The state would remain free to raise revenue in a different way, through a different tax that did not violate the Constitution. But it would be incumbent upon the courts to force the state to disentangle the constitutional from the unconstitutional.

So, too, here. In most states, there is no doubt that punitive damages are used primarily as punishment. That is how the plaintiff's lawyer explains them to the jury. ${ }^{383}$ That is how the trial court instructs the jury. ${ }^{384}$ And that is what

379. See id. On this last point, Judge Calabresi has in mind what he calls the "tragic choices" function of punitive damages: the self-contradictory fact that we generally want manufacturers to make efficient cost-benefit analyses in determining how much to invest in product safety, but at the same time we do not want to allow them to defend against liability on efficiency grounds when their products tragically cause injury or death. See id. at 340-43.

380. See id. at 348 .

381. For an argument contrary to Judge Calabresi's, see Geistfeld, supra note 23 , at $1115-16$, which argues that when the Court imposes constitutional limits that are premised on a particular conception of the nature of tort liability, the states can get around those requirements by explicitly grounding their tort law in a different conception, and thus the Court's decisions "can serve the valuable role of forcing state courts and legislatures to identify more clearly the substantive objectives of tort liability."

382. See generally Harper v. Va. Bd. of Elections, 383 U.S. 663 (1966) (declaring a poll tax unconstitutional).

383. See Colby, supra note 9 , at $584 \&$ n.3.

384. See id. at 610 . 
tends to drive the jury's verdict. ${ }^{385}$ They are, after all, called punitive damages. The constitutional implications of that reality cannot be avoided by the fact that they might on other occasions, or even simultaneously, serve other goals goals that the states are free to continue to pursue once they disentangle them from punishment. The states are free to maintain extracompensatory remedies, even muddled ones that simultaneously serve any number of state interests, so long as one of those interests is not the punishment of public wrongs. Williams was thus correctly decided, notwithstanding its interference with the traditional role of the states in shaping the law of torts. Tort law - like all lawis constrained by the Constitution. ${ }^{386}$

\section{CONCLUSION}

Although its reasoning was incomplete and at times misguided, the Supreme Court ultimately got it right when it held in Philip Morris USA $v$. Williams that the Constitution prohibits the use of punitive damages to punish a defendant for harm caused to persons not before the court. To punish the defendant for the wrong done to the plaintiff is to vindicate the plaintiff's private interest in revenge-a legitimate goal of the civil law. To punish the defendant for the total harm visited upon all of society, by contrast, is to vindicate the public's interests in retribution and complete deterrence. Those interests, however, are the province of the criminal law, and the Constitution does not allow the state to outsource their vindication to private parties in an end run about the procedural safeguards guaranteed to criminal defendants by the Bill of Rights. This Article argues that that is the true justification for the Court's holding in Williams, and it suggests that one consequence of that fact is that Williams does not stand in the way of implementing a law-andeconomics-inspired cost-internalization sanction that is not a form of punishment and thus does not implicate the concerns of the criminal law.

385. See Cass R. Sunstein et al., Punitive Damages: How Juries Decide 70, 73, 134 (2002) (concluding based on empirical research that retribution drives juries' punitive damages awards); Daniel Kahneman, David Schkade \& Cass R. Sunstein, Shared Outrage and Erratic Awards: The Psychology of Punitive Damages, 16 J. RisK \& UNCERTAINTY 49, 72-73 (1998) (concluding, based on empirical research, that the size of a punitive damages award generally depends on the jury's retributive intent). For an example of the extent to which juries view punitive damages as a form of genuine punishment, see Arnett $v$. Fuston, 378 S.W.2d 425, 430 (Tenn. Ct. App. 1964), in which the jury concluded, "We declare L. D. Fuston guilty of the charge and recommend a judgment of $\$ 30,000.00$ against him and punitive damages from one to five years in prison."

386. See, e.g., N.Y. Times Co. v. Sullivan, 376 U.S. 254 (1964). 